\title{
حالة الطوارئ و أثرها على حقوق الإنسان المدنية ( دراسة دستورية هقارنة في الحالة العراقية )
}

\author{
shel \\ د. / مصطفى سالم مصطفى النجيفى \\ أستاذ القانون العام المشارلك \\ كليتتالقانون بجامعت الشارقت \\ بفرعى خورفكان وكلباء
}


كما هو معلوم لا تسير الحياة في الدول المعاصرة على وتيرة واحدة وثابتة قو امها الامن والسلام والهاوع ، فقد تواجه الاولة ظروفاً خارجة عن المسألوف الطبيعي

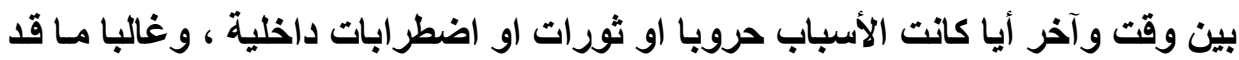

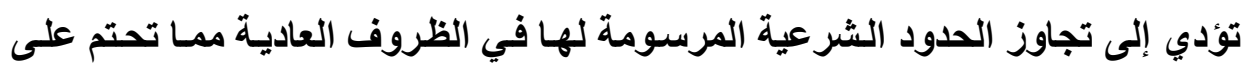

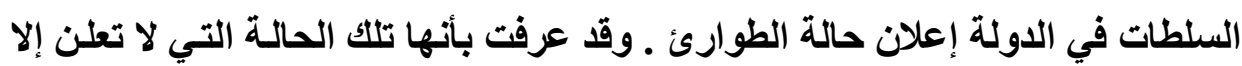

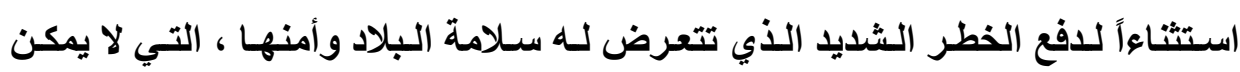

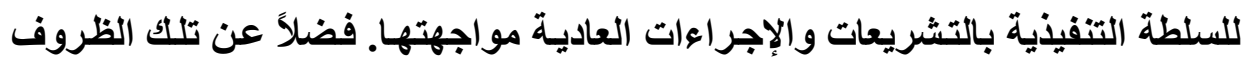
الاستثنائية غير اعتيادية وخارجة عن المألوف التي تهلد السلامة العامـة والامن العام

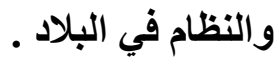

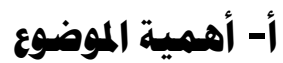

تنبع الهية الموضوع في معرفة الى أي مدى اثرت حالة الطوارئ على الحقوق العدنية للإنسان وخاصة الفرد العراقي ذلك ان اهية دراسة هذا الموضوع بالبحث جاء الهاء

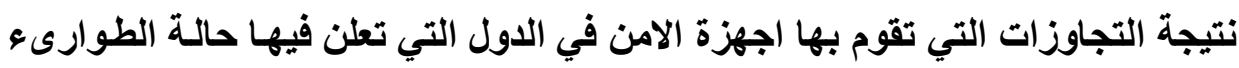
ومنها العراق بالتحديد، ومدى التخفيف من الاضرار التي تصيب الافراد جراء تطبيق

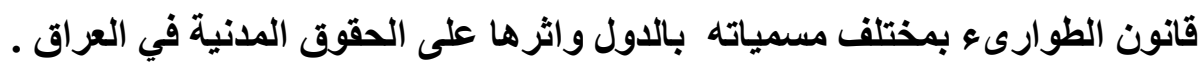
ب- اشكالية البحث والهدف هنه:

تكمن اشكالية البحث من خلال التساؤلات على موضوع البحث للوصول الى الى الهذف المنشود في احترام حقوق الانسان وحرياته ومنها الحقوق المدنية موضوع

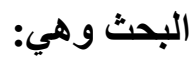


هناك عدة تساؤلات تحيط بموضوع البحث تحتاج إلى إجابات وهي : ا - إلى أي مـدى جاء إعلان حالة الطوارئ متوافقا مع الاساتير والتشريعات . r - هـل أن قانون الطوارئ (قانون الدفاع والسلامة الوطنيـة الحـال) قـ جـاء مطلق الحدود ام نسبياً.

r- ما مشروعية قانون السلامة الوطنية الذي صدر في ظل سلطة الاحتلال الامريكي. ع - هل نجحت السلطات المختصة العراقية الامنية باتخـاذ الاجراءات الايجابية لخلق الامسـان والطمأنيــة في نفس المـواطن العراقي. وهـل ان سـلوك القوات الامنيـة العراقية جاء منضبطا ومتو افقا مع احكام القانون. وهل تمت محاسبة المقصرين من افراد قوات الامن تجاه الافعال التي يقومون بها تجـاه الافراد وايقاف ظاهرة التعذيب بحق المعتقلين للديها وصيانة كرامتهم الشخصية ويسرت الاجراءات القضائية للمتضررين في سبيل اللجوء للقضاء ـوهل ان جميع حالات القاء القبض على المشتبه بهم تتم وفق القانون وياوامر قضائية. هـ مـا هو دور المؤسسة القضائية العراقيـة امـام هذه الانتهاكـات الجسيمة لحقوق الانسان ومنها حقوقه المدنية ودور الادعاء العام في العراق.

ج- منهبة البحث :

يحكم هذا البحث المنهج القانوني المقارن والمنهج الوصفي من خلال عرض موقف الاساتير والتشريعات ، وفي إبراز العيوب التي تلحق بقرارات سلطة الطوارئ .

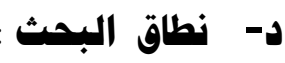
يكمن نطساق الدراسـة في تنظيم حالـة الطوارى عـي دسـتور العراق ومـصر والتشريع الخاص بها والحدود المرسومة التي ينبغي على المشرع الوطني التقيد بها. 
تم تقسيم البحث الى مطلب تمهيدي واربعة مباحث وكالاتي:

المطاب التههيدي/ ماهية مبدأ المشروعية.

تعريفه ، مصادره ، ضماناته

المبحث الاول ماهية حالة الظوارى\&

تعريفها ، انواعها ، خصائصها ، تمييزهاعن مايثابهها.

المبحث الثاني / اساس حالة الطوارىء وتنظيمها القانوني.

المبحث الثالث / القواعد العامة لحالة الطوارىء وشروطها.

المبحث الرابع / اثر اعلان حالة الطوارىع على الحقوق المدنية

مفهوم الحقوق المدنية ، انواعها ، واثر الطوارىع عليها.

الخاتهة وتتضمن النتائج والتوصيات 


\begin{tabular}{|c|c|}
\hline د / مصطفى سالم مصطفى النجيفى & العدد عا (ديسمبر Y|r) \\
\hline
\end{tabular}

\section{المبحث الأول}

\section{ماهية حالة الطوارى}

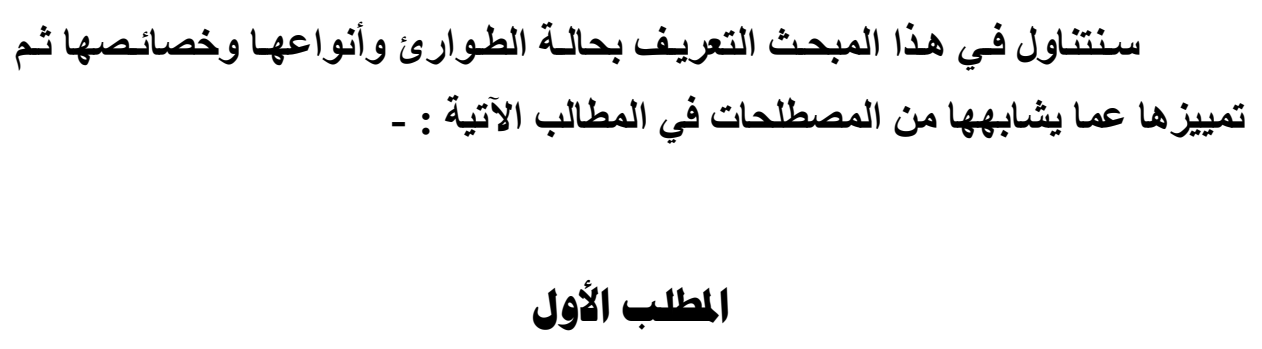

\section{التعريف بمالة الطوارئ}

وستناول في هذا المطلب التعريف بحالة الطوارئ ونشأتها وأنواعها وتميزهـا عما يشابهها من النظم في الفروع الآتية :-

\section{الفرع الأول \\ تمريف حالة الطوارئ}

لا يوجد تعريف محدد لحالة الطوارئ متفق عليه فمنهم من عرفها بأنها نظام

قانوني يتقرر بمقتضى قوانين دستورية عاجلة لحماية المصالح الوطنية ، ولا يلجأ إليه إلا بصفة استثنائية ومؤقتة لمواجهة الظروف الطارئة التي تقصر عنها الأداة الحكومية الشرعية وتنتهي بانتهاء مسوغاتها (').وهنـاك من يعرف حالة الطوارئ بأنسه ( تدبير (1) د. زكريا محفوظ ، حالة الطوارئ ، دراسة مقارنة ، طا ، منشأة المعارف ، الإسكندرية ، 1979 صrr|. 
قانوني مخصص لحمايـة كل أو بعض أجزاء البلاد من الأخطـاء الناجمـة عن عدوان مسلح ) (') وعرّقت كذلك بأنها نظام قانوني محدد لمواجهة الظروف الاسنثائية ويقوم مقام قوانين السلطة الكاملة ، وبالنسبة لهذا التعريف فإنه استتد في التعريف إلى وجود أو إعلان حالة الطوارئ وأنه يخلط بين طبيعة حالـة الطوارئ وقوانين السلطة الكاملة إذ ترخص الأولى للسلطات القائمة على حالة الطوارئ باتخـاذ تدابير استثنائية تختلف

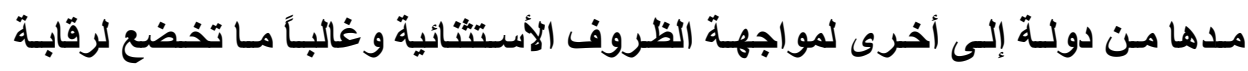
برلمانيـة وقضائية ، أمساقـوانين السلطة الكاملـة فهي تـرخص للحكومـة اتخـاذ كافـة التدابير اللازمـة لإعادة بنـاء الوطن في فترات الحرب ومـا بعدها فالسلطة التشريعية بموجب هذه القوانين تمنح تفويضاً وبدون قيود للسلطة التنفيذية لتتخذ إجراعات تدخل أساساً في اختصاصات البرلمان() ، وعلى الرغم من كل ذلك سواءً وردت نصوص أم لم ترد فإن هذه الحالة وجدت أصلاً لمواجهة حالة استثنائية تمر بها الدول لتتمكن سلطات الدول من مراجعتها وهناك من يعرف حالة الطوارئ بـ (أنها نظام بمعنى من المعاني ـ نظام تفرضه سلطة محصنة ـ وليس العدالة) (“). وحالة الطوارئ هي نظام

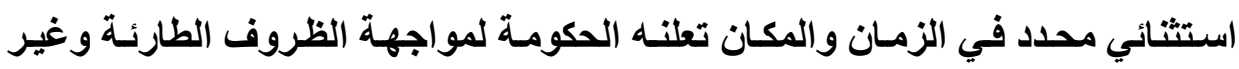
العادية التي تهدد أمن البلد وذلك بتدابير مستعجلة وطرق غير عادية في شروط محددة

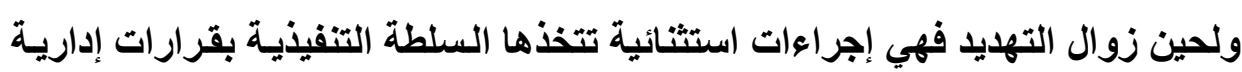

(1) رديـف مـصطفى - حالـة الطـوارئ - مبرراتها ، مسشرو عيتها القانونيـة والاسـتورية وآثرهـا وضوابطها ، وردت الإشارة إليه في الموقع :

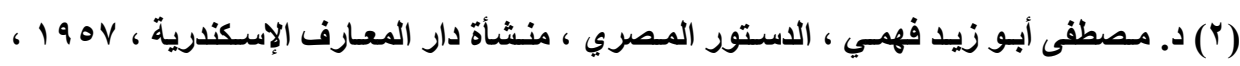

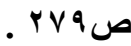

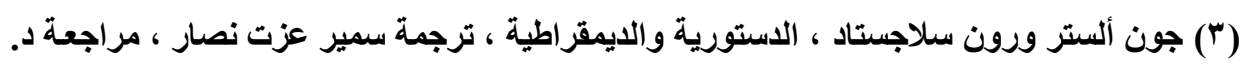

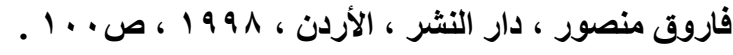


في أحوال محددة على سبيل الحصر وضـمن شـروط معينةة(')، فهو نظـام استثنائي شرطي مبرر بفكرة الخطر المحيق بالكيان الوطني يسوغ اتخاذ تدابير قانونية مخصصة

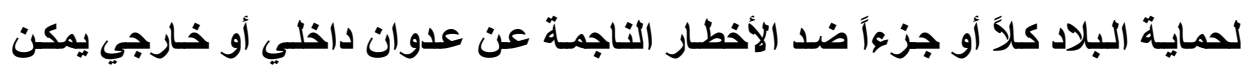
التوصل إلى إقامته بنقل صلاحيات السلطات المدنية إلى السلطات العسكرية(؟) ، ولمّا كان التعرض للخطر سبباً لإعلان حالة الطوارئ وقيامها يعد سبباً واسعاً فضفاضاً ، حيث لا يمكن وضع أي تحديد منضبط ودقيق لمدلول التعرض للخطر ، فإن المشرع في فرنسا ومصر حدد بنفسه مصادر ذلتك الخطر ، فحصرها في فرنسا في أمرين همـا الحرب الخارجية والاضطرابات المسلحة ، أما المشرع المصري فإنه توسع فيها فحدد تلك المصادر في أمور خمسة هي : وقوع الحرب ـ قيام حالة تهديد بوقوع حرب - حدوث اضطرابات في الداخل -

$$
\text { حدوث كوارث عامة ـ انتثار وباء . }
$$

ومـا مسن شـك في أن تعداد مـصادر الخطر التـي تجيز إعـلان حالـة الطوارئ وحصرها على وجه التحديا بهذه الطريقة من شـأنه أن يساهم في الحــ من احتمـالات تعسف السلطة التنفيذية في هذا الصدد ، حيث لا يسوغ لها إعلان حالة الطوارئ إلا إذا

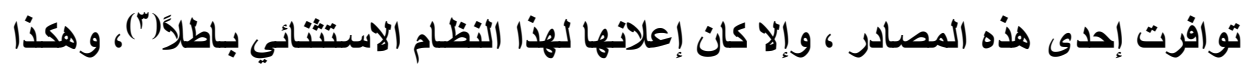
تثكل حالة الظوارئ ظرفاً استثنائياً يسمح بنظر القانون للسلطة في بلا ما بـالتحرر من التزامسات دستورية محددة مـع ضمان النواة الصلبة للحقوق الأسساسية للإنسان غير 
القابلة للمساس بها"'). هذا وإن حالة الطوارئ نظام قانوني استثنائي تعطي بموجبه السلطات المدنية عند حدوث الأخطار امتيـازات استثنائية لتسمح لها بتقييد ممارسـة

$$
\text { بعض الحريات (י) }
$$

\section{الفرع الثاني}

\section{أنواع حالة الطوارئ}

يوجد عدد من التعبيرات المستخدمة في مجال حالة الطوارئ، وهي بهذا الصدد لا تعتبر نوعاً من الخلط الاصطلاحي ، فقد تثبر الحالة الطارئة إلى تطبيق نظام الأحكام العرفية السياسية ويسمى (حالة الطوارئ السياسية)، كمـا قد تشير إلى تطبيق نظام

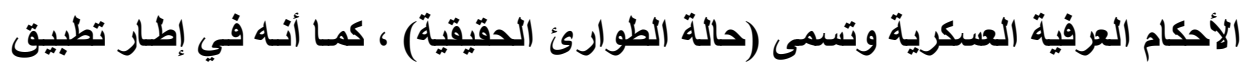

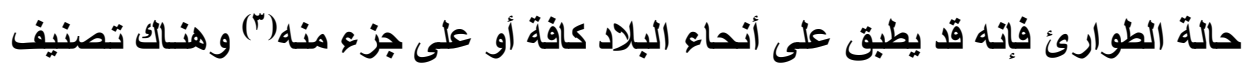
آخر يعتمد على الانحراف عن إطار المشروعية الدولية كقاعدة له. أولاً الأحكام العرفية العسكرية والأمكام العرفية السياسية : 1 - الأحكام العرفية العسكرية : وتسمى كذلك حالة الطوارئ الحقيقية بسبب النتائج الخطيرة المترتبـة عليه بحيث يملك القـادة العسكريون في هذه المنـاطق سلطات خطيرة تبيح لهم تعطيل الاستور والقوانين في هذه الأمسكن، وتقييد حقوق الأفراد

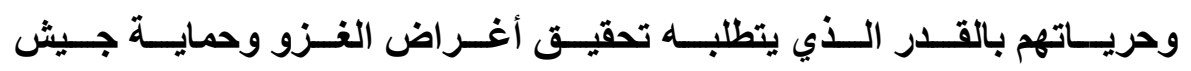

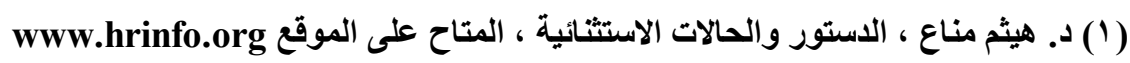

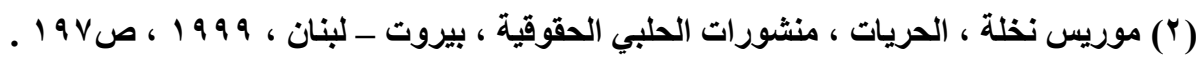

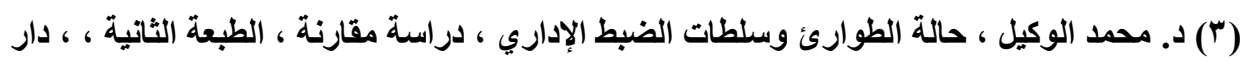

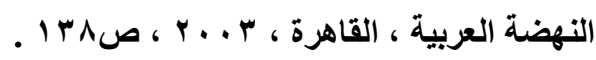


الاحتلال(')،والأحكام العرفيـة العسكرية هي من المنظور التـاريخي تتبع من حالة حرب حيث تعرف بأنها (الحالة التي تعبر عن وضع مكان محاصر وبتعبير أدق منطقة وولاية في حالة حرب) وتتمثل خطورتها في النزاعـات الداخلية التي تهدد

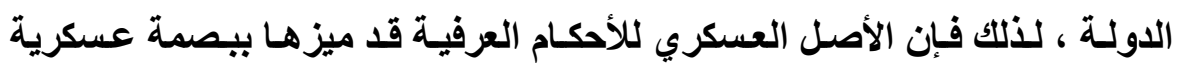
يجعلها قليلة التوافق مع متطلبات الأزمـة السياسية، فالأحكام العرفية العسكرية لا تنطبق إلا في حالـة قيسام حرب سـواء أكانـت هذه الحرب هـي دفاعيـة أو حملـة

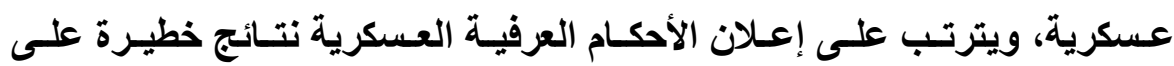
الحريـات والحقوق الثخصية نظراً لمـا تتطلبهـ ظروف الحرب من طـابع الحزم والسرعة سواء فيما يتعلق بالعمليات الحربية أو فيما جاوز ذلك من مشكلات قد لا

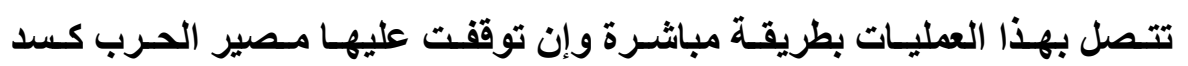
احتياجـات القـوات المسـلحة وتـوفير وســائل الإمـــادات والتمويـلـ أو مـضـاعفة الصناعات الحربية ومراقبة المشتبه بهم في تعـاونهم مـع الأعداء أو من حيث مواجهة مشاكل لاجئي الحرب أو منكوبيها أو مقاومة هبوط الروح المعنوية بهدف كسب الحرب لذلك تتسع السلطات الاستثنائية الممنوحة للسلطة العسكرية حيث تتحول السلطات المدنية الممنوحة لسلطات الضبط الإداري إلى السلطات العسكرية إن اقتضى الأمر ذلك أو أن تباشر هذه الاختصاصات بوصساية السلطات العسكرية

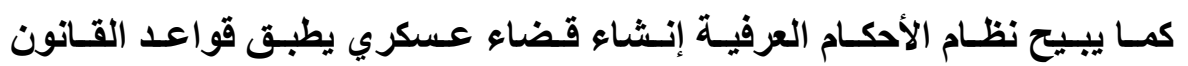
العسكري بدلاً من قواعد القوانين المدنية كما يبيح نظام الأحكام العرفيـة العسكرية العاعية للقائد العسكري في أن يطبق قواعد القـانون العسكري في منـاطق معينـة في حسال قيام الحرب خارج أرض الوطن أو داخل أرض الدولة نفسها عند تعرضها للفزو أو

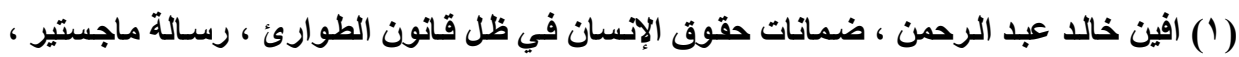

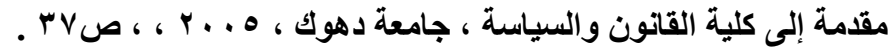


العصيان أو الاضطر ابات التي قد تسهل حالـة التمرد ، ويتفق الفقهـه في أن هذا

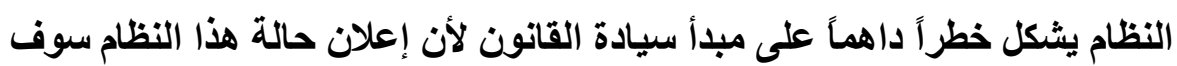
يصاحبه تعطيل عمل القوانين العادية وتعطيل عمل المحاكم العادية مما يترتب عليه إهدار الضمانات المقررة للحريات والحقوق ويحيل الوضع إلى حكم عسكري يسير على وفق أهواء ورغبات السلطة العسكرية(')

r- الأحكام العرفية السياسية (حالة الطوارئ السياسية) : وتعلن بواسطة السلطة التنفيذية في البلاد كلها أو في جزء منها ، وذلك عند قيام خطر داهم يهدد أمن البلاد وسـلامتها ، وذلك نتيجـة التهديـ بوقوع حرب أو قيسام اضطرابات داخليـة

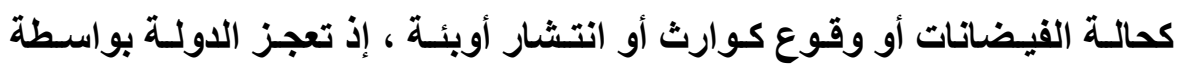
قوانينها العادية عن مجابهة الحالة وتنفيذ حكم القانون بالأسـاليب المعتادة () ، وهي تهدف إلى تقوية السلطة التنفيذية لذلك فهي تمنحها سلطات خاصسة بعضها من اختصاص السلطة التشريعية والبعض الآخر من اختصاص السلطة القضائية ، وكذلك يرخص لها بوقف العمل ببعض الحقوق إلى الحد الضروري لمجابهة الحالة الطارئة وفي كل الأحوال لا يعني ذلك المساس بـالحقوق الأساسية فهذا النظام أي (نظام الطوارئ) إن كان نظاماً استثنائياً إلا أنـه ليس بالنظام المطلق فهي محددة وفق القـانون ولـه ضـوابطه وحـدوده وأحكامهـا التـي يجب الالتـزام بهـا وعـدم ت تجاوزها. 


\section{ثانيًا- حالة الطوارئ الكلية وحالة الطوارئ الجرئية :}

إذا كانت حالة الطوارئ مرتبطة بوجود ظروف استثنائية شـاذة محددة مسبقاً

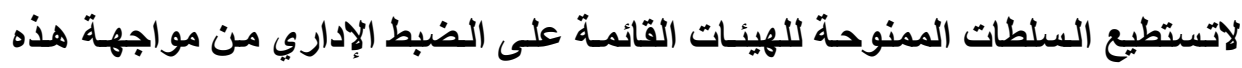

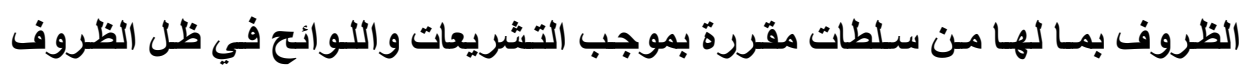
العادية فإن هذه الظروف والأحداث قد تشمل كامل إقليم الدولة أو قد تتركز في جزء

1- حالة الطوارئ الجزئية : وتتمثل هذه الحالة إعلان حالة الطوارئ على جزء داخل

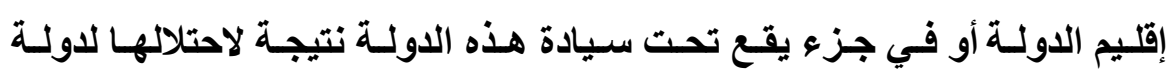

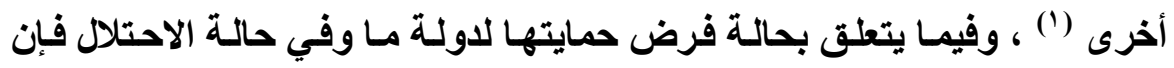

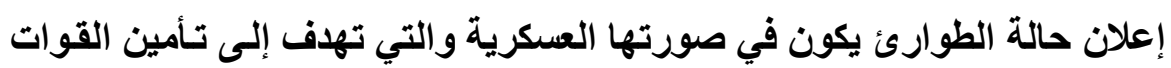

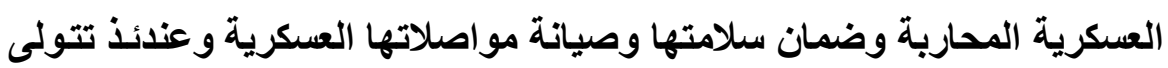

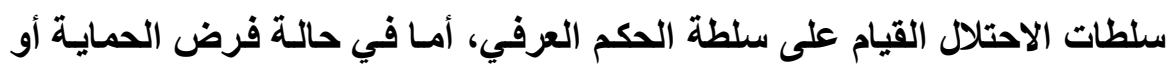

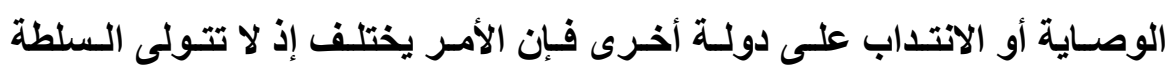

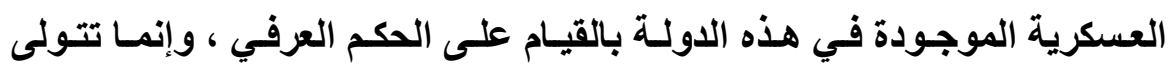

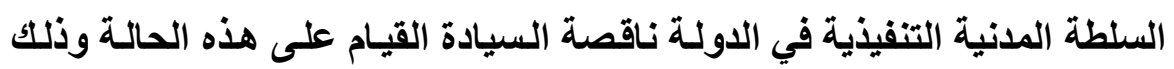
تحت إثراف ووصاية مبعوث الدولة المتبوعة وغالباً ما يسمى بالمندوب السامي التهاي

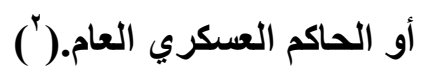




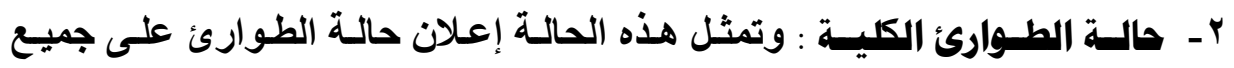

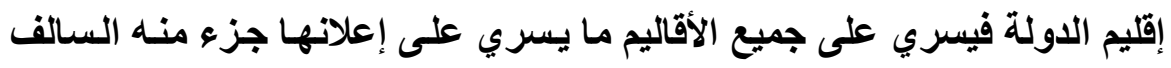

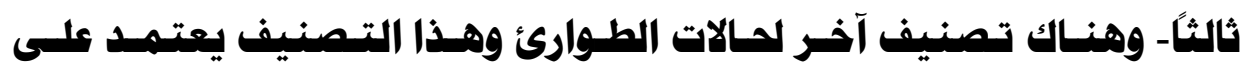
الانشراف عن إطار المشروعية الدولية كقاعدة له وتتمثل في :

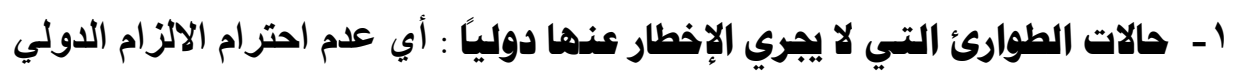

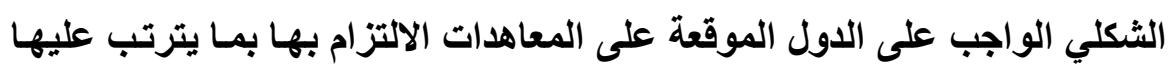

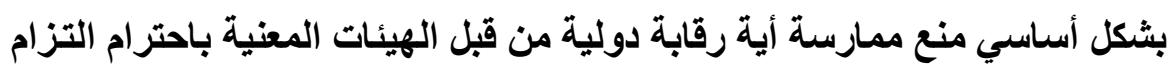
الدولة بتعهداتها .

r- حالة الطوارئ الطويلة الأهد (الزهاني) : وهي الحالات الناجمة عن تمديد نسقي لحالة استثنائية واقعية أو استمرارها في غياب التحديد الزمني في القانون المحلي

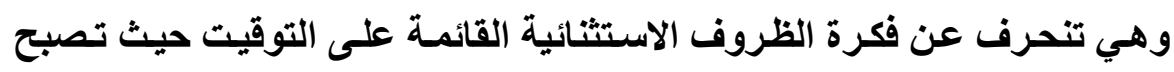
القاعدة هي الاستثناء ويهمش القانون العادي مع تراكم القرارات الاستثنائية عبر

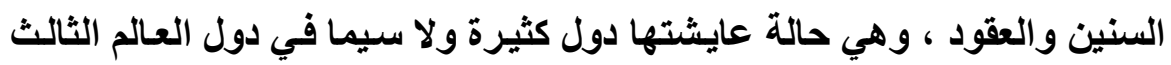

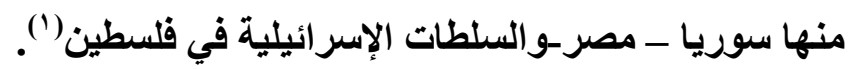




\section{الفرع الثالث \\ خصائص حالة الطوارئ'(1) :}

\section{أولاً - نظام حالة الطوارئ نظام استثنائي يخضع لمبدأ المشروعية الاستثنائية:}

أقرت معظم الدول التي تأخذ بنظسم الطوارئ وأيـاً كانت طريقة أسلوب تنظيم

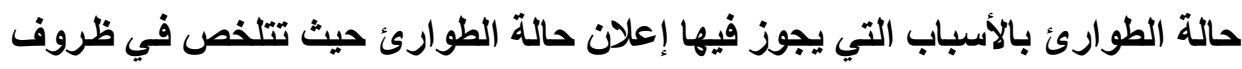

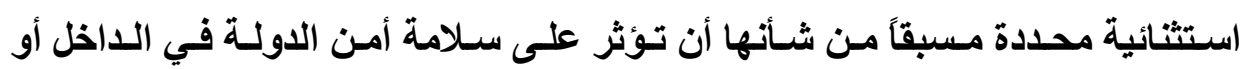

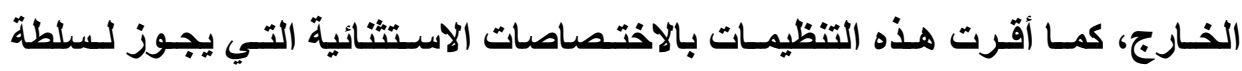
الطوارئ اتخاذها - وهذه الاختصاصات الاستثنائية وكمـا سنوضحه لاحقاً ، قد تكون

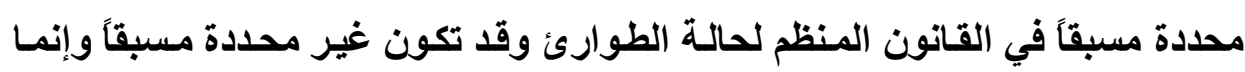
تحدد وفقاً لظروف الحال - والتي تتحلل بموجبها من قواعد المشروعية العادية التي لم الم توضع إلا لمواجهة الظروف العادية لتخضع لقواعد مشروعية جديدة استثنائية تتمثل في القوانين المنظمة لحالة الطوارئ .

\section{ثانيًا - نظام حالة الطوارئ نظام جوازي :}

يتفـق معظـم تـشريعات الطـوارئ علـى أن تطبيـق حالــة الطـوارئ هـو نظــام

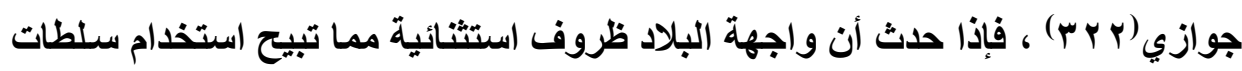

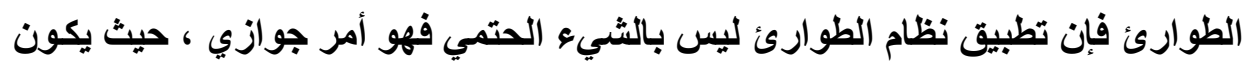

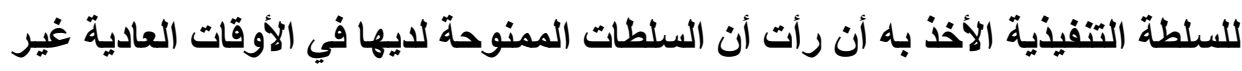

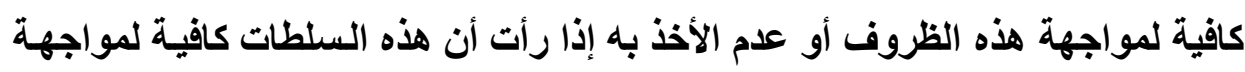

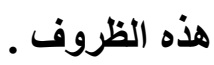

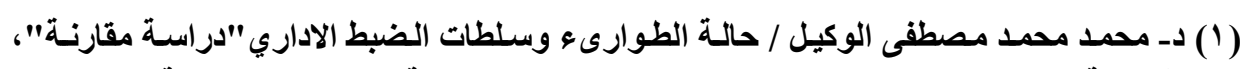

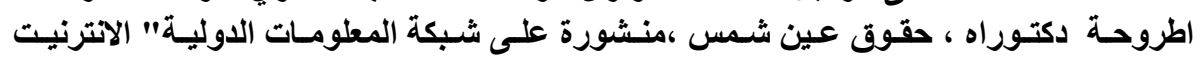


ثالثًا - نظام حالة الطوارئ هو نظام هؤقت :

تتفق معظم تثريعات الطوارئ على أن إعلان حالة الطوارئ يكون لفترة مؤقتة حيث ترتبط حالة الطوارئ وجوداً وعدماً بظروف استثنائية تواجها البلاد ، وغالباً مـا

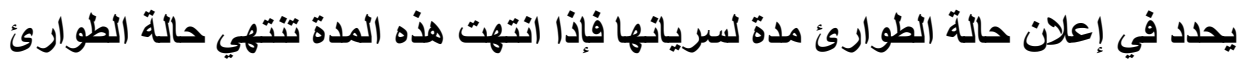

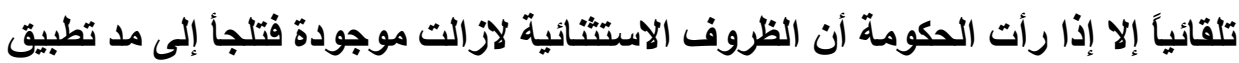
حالة الطوارئ وفقاً للنصوص الاستورية والقانونية المنظمة لحالة الطوارئ.

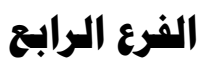

\section{تمييز حالة الطوارئ عما يشابهها هن أنهاع اخرى .}

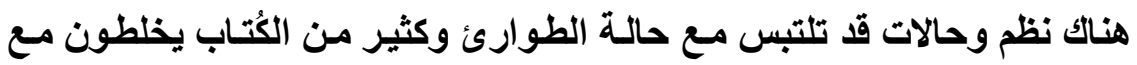
بعض هذه المصطلحات ، ولذا كان لا بد من الإثـارة لتلك الحالات لأغراض الإيضاح

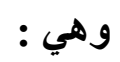

\section{أولاً- التهيز بين حالة الطوارئ والأحكام العرفية.}

هناك خلاف في الفقه القانوني حول كل من مصطلح حالة الطوارئ ومصطلح الأحكام العرفية ففي حين يرى معظم الكتاب أن المصطلحين يدلان على المغنى نفسه إلا فئ

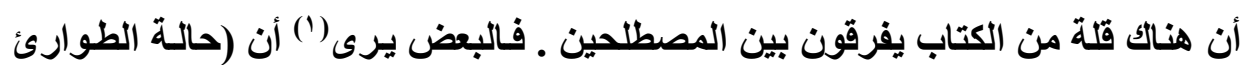
في بعض الأوجه) أقل شدة أو جسامة من الأحكام العرفية ، لم يكن من المككن أولاً قبل

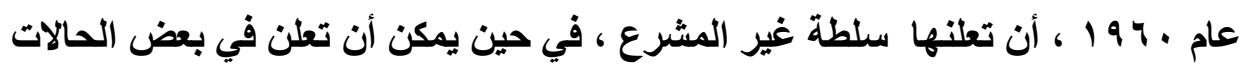

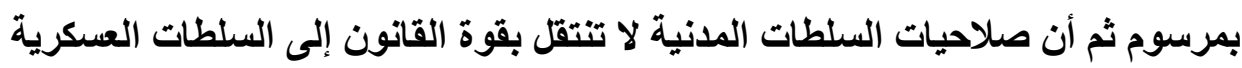

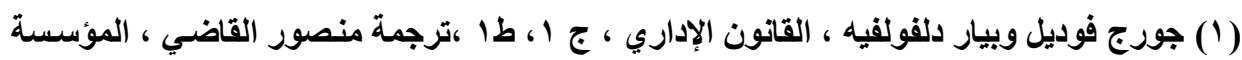

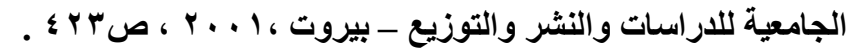


في حالة الطوارئ في حين تنتقل على هذا النحو في حالة الأحكام العرفية وبأن (حالة

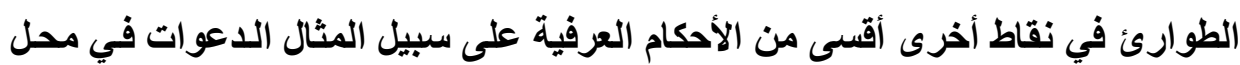
الإقامة منصوص عليها صراحة في القانون حول حالة الطوارئ في حين أنه ليس كذلك الكائ

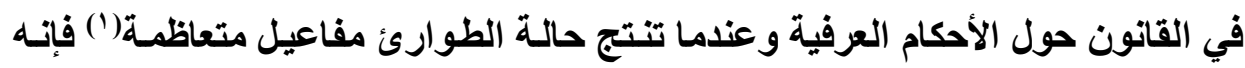

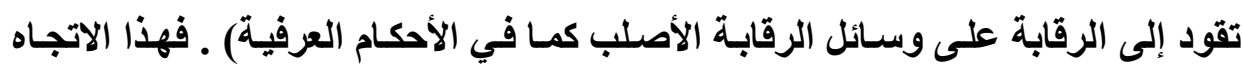

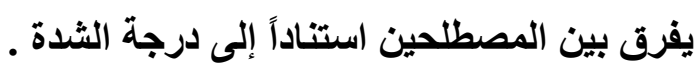

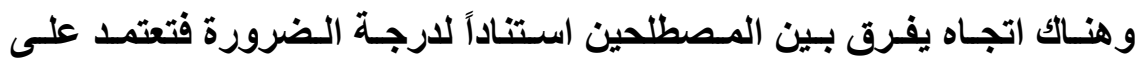

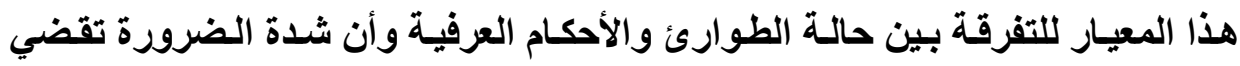
إلى إعلان حالة الطوارئ وهي أقل من شدادة الضرورة التي تستلزم إعلان الأحكام

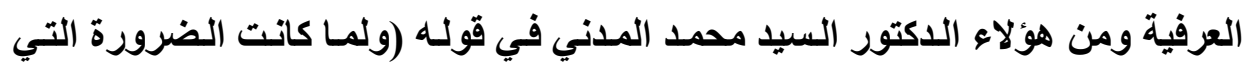

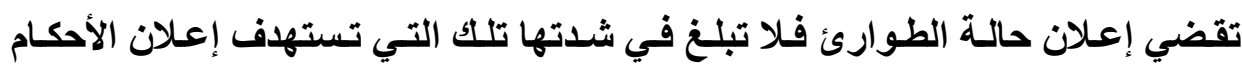

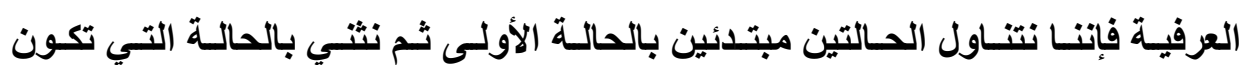

$$
\text { ضرورتها أثند). (ن) }
$$

وهناك اتجاه في الفقه يدمج بين المصطلحين ويجعل منهما ذات دلالدة واحدة فالدكتور رعد ناجي الجدة في مؤلفه (التطورات الدستورية في العراق) لم يفرق بين

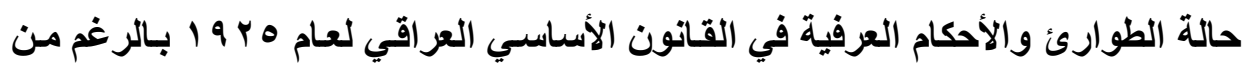

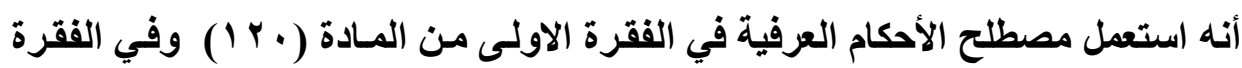

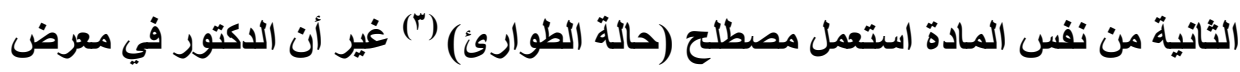

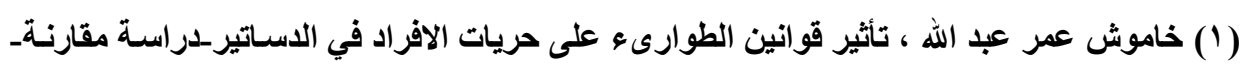

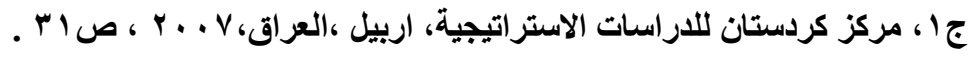

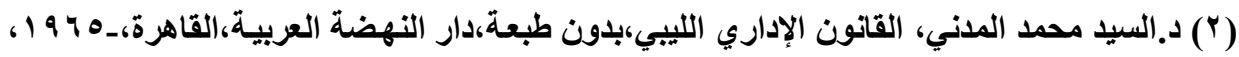
ص\&

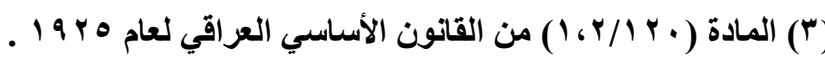


شرحه له ذكر (وعلى هذا الأسساس فإن الأحكام العرفية تقرر من قبل مجلس الوزراء

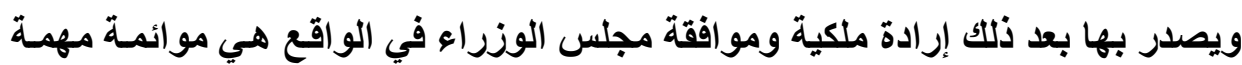
لأجل أن تتحمل الـوزارة المسؤولية التي تنجم عن هذا الإجراء الخطير ولا تنتهي التهي

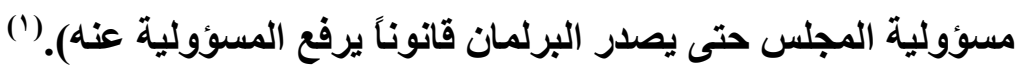

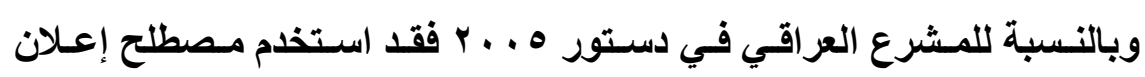

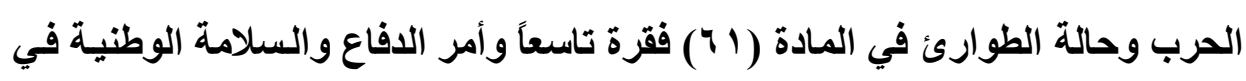

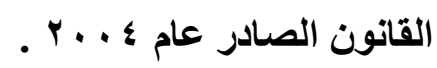

\section{ثانيًا- التمييز بين حالة الطوارئ وهصطاح مكافهة الإرهاب :}

يعتبر الإرهاب ظاهرة قديمة غير أنها انتشرت بشكل كبير جداً في هذا العصر

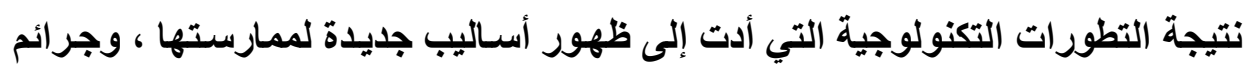

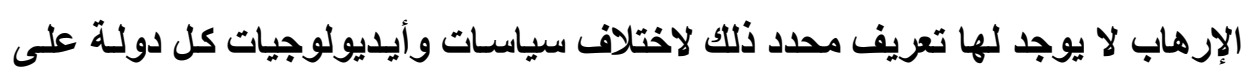

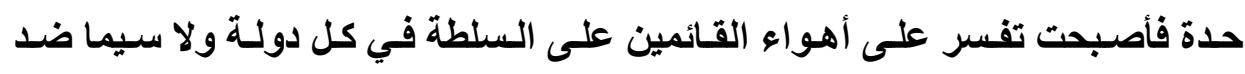

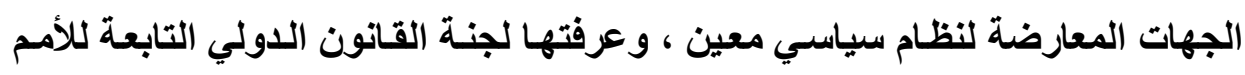

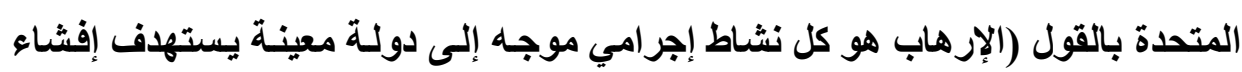

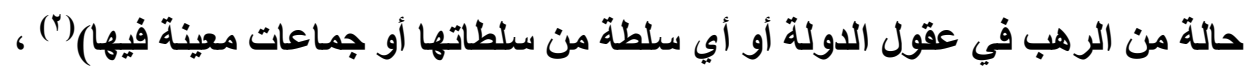

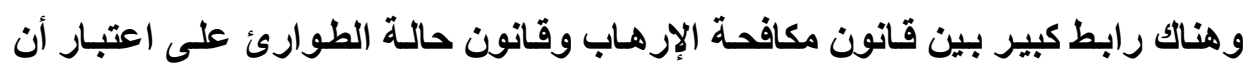

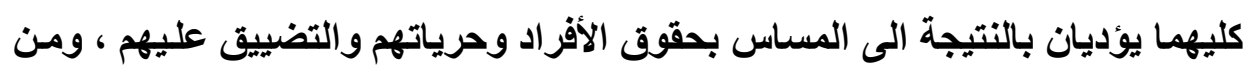

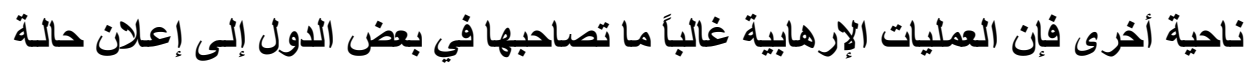

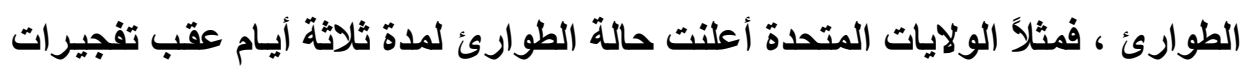

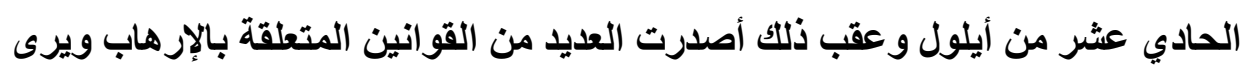

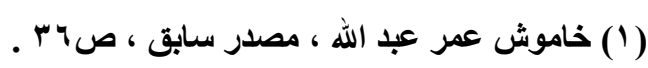

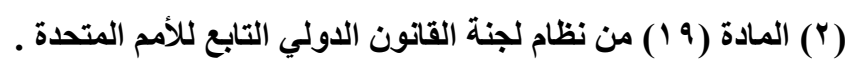

مجلة البحوث القانونيت والإقتصاديت بr 
كثير من المراقبين بأن هذه القوانين والقرارات أقرب إلى حالة الطوارئ (') ، وعلى فئل

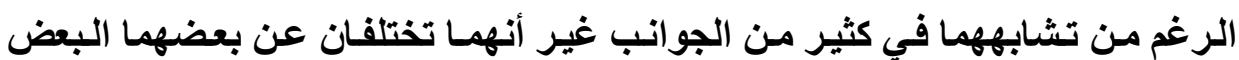

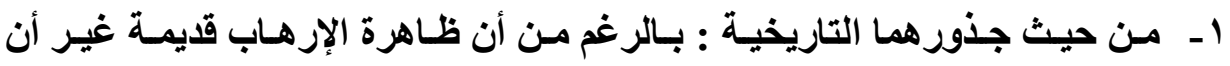

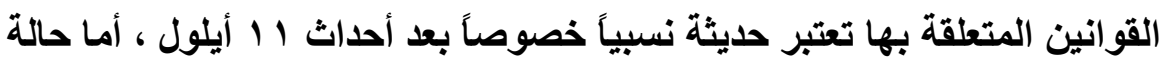

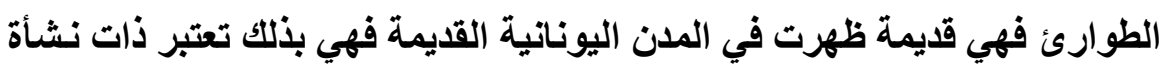

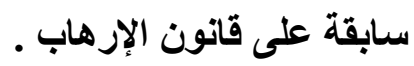

r- من حيث الموضوع : مكافحة الإرهاب كما يستنتج من التسمية وجد أصلاً لمكافحة الجرائم المتعلقة بالإرهاب فاختصاصه ينحصر في تناول موضوع التوان مكافحة الإرهاب

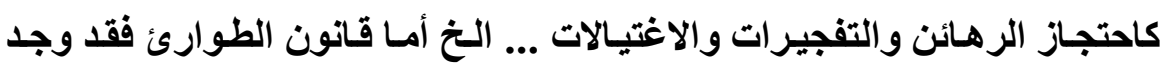

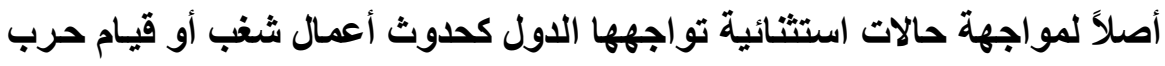

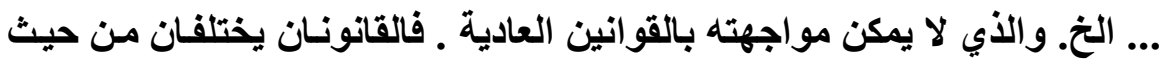
تناول كل منهما الموضوع بشكل مختلف عن الآخر .

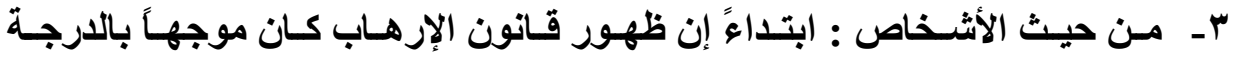

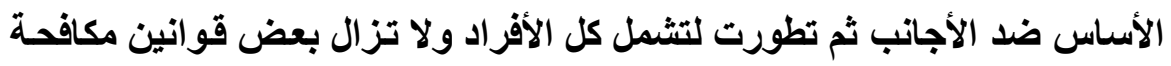

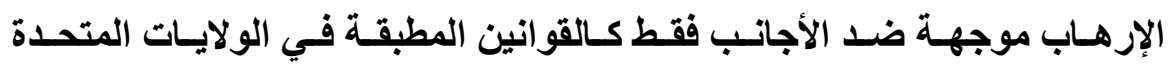

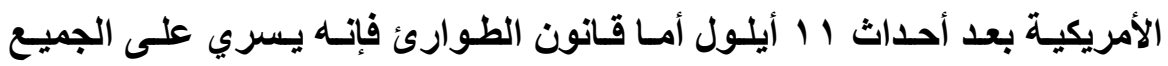
مواطنين وأجاتب في المكان المعلن فيه . 
ع - مـن حيث الزمن : يعد قـانون الطوارئ قانونـاً وقتيـاً يجـري العمل بـه لمواجهـة ظروف معينة ، فهي مؤقتة بفترة زمنية معينة على خلاف قانون مكافحة الإرهـاب

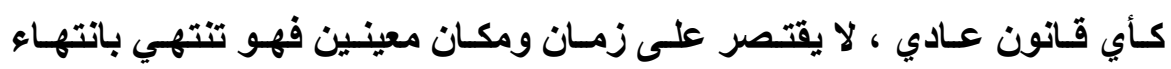
القوانين العادية .

\section{ثالثًا- التمييزز بين حالة الطوارئ والساطة التقديرية للإدارة :}

ويقصد بالسلطة التقديريـة لـلإدارة (تمتعهـا بقسط مـن حريـة التصرف وهـي

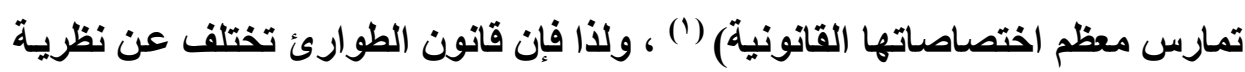
السلطة التقديرية في عدة جوانب منها :

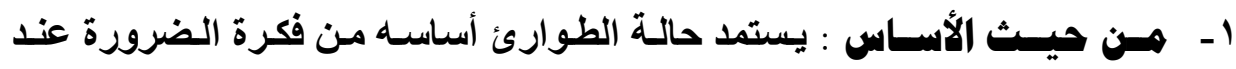

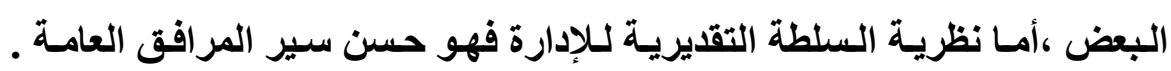

وكذلك فإن اعتبارات تغير الظروف وتظورها تجعل تنظيم كل دقائق نشاط الإدارة بقواعد محددة وموضوعة سلفاً مما يجب منحها قدراً من حرية التصرف في بعض الأمور .

r - مـن حيـث المجـال الزمنــي : إن نظريـة السلطة التقديريـة نظريـة دائمسة في كل

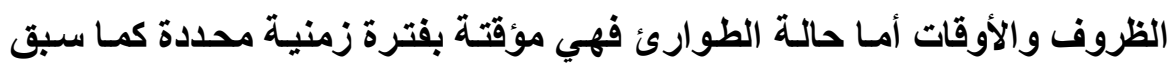

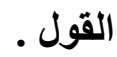

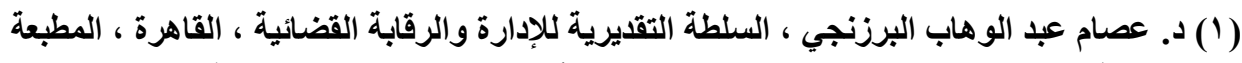

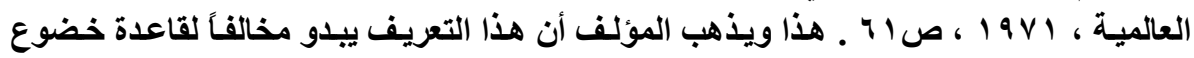

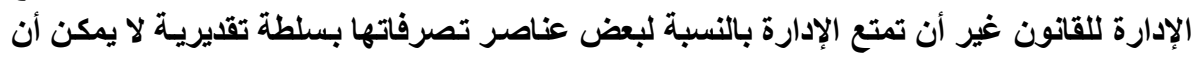

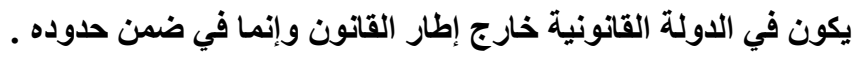




\section{المبحث الثاني \\ أساس حالة الطوارئ وتنظيمها القانوني البئي}

وسنتناول في هذا المبحث أساس حالة الطوارئ وتنظيمها القانوني في المطالب

\section{المطاب الأول \\ أساس حالة الطوارئ}

تجد اساس حالة الطوارئ في نظريـة الضرورة كأسساس فلسفي لها وسنتاول الطوائ

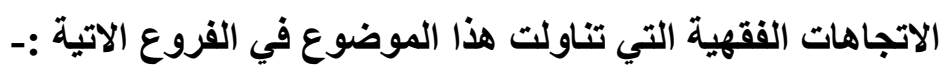

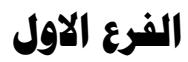 \\ حالة الضرورة نظرية سياسية واقعية}

ان المبأ الاساسي الذي اتخذه اصحاب هذه النظريـة هو مبدأ سيادة القانون، التانه

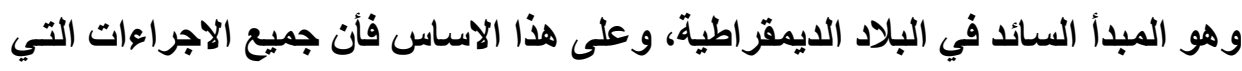

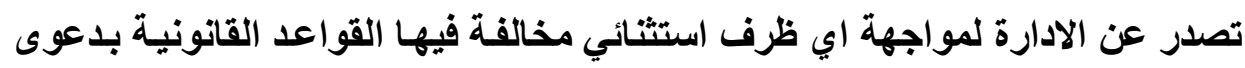

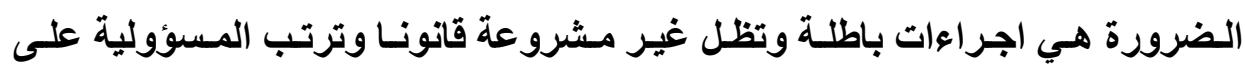

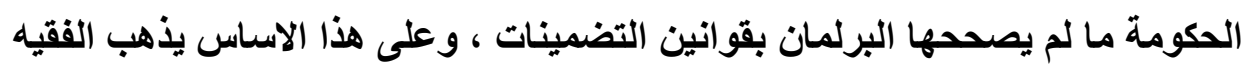

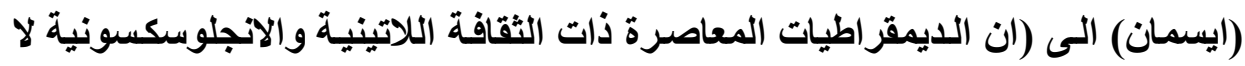

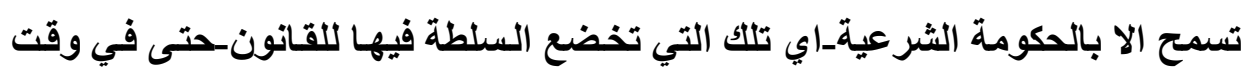
الازمات)(')، وفي الاتجاه نفسه يذهب الفقيه" كاريه دي مـالبيرك" من خلال تصويره

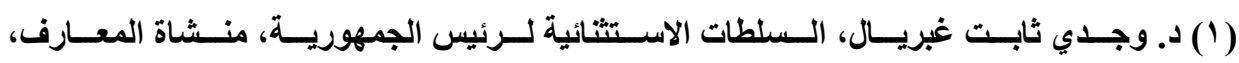

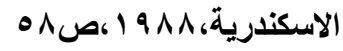


لمفهوم الضرورة قائلا" لماذا نريد ان نكابر بـأ ضفاء صيغة قانونية على مـا ليس الا حيلة واقعية تفرضها الضرورات العتمية " (') وهذا هو اتجاه الفقه الفرنسي القديم. امـا في بريطانيا وامريكا فقد استقرت احكام القضاء على اعتبار نظرية الضرورة مجرده

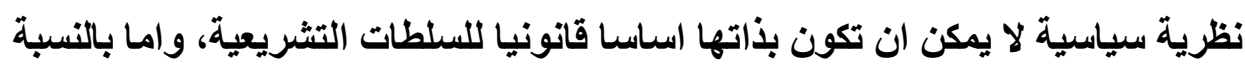

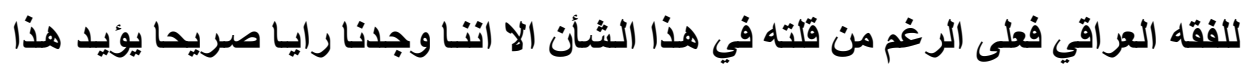
الاتجاه الأي يرى ان الضرورة لاى الفقه والقضاء العراقي انها ليست نظريـة قانونية تبيح للاولة التحلل بالكامل من اسس مبدأ المشروعية في ظل الازمسات ، وانمـا هي

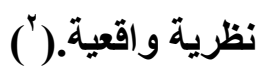

\section{الفرع الثانتي \\ حالة الطوارئ نظرية قانونية}

يعتبر اصـحاب هذا الاتجـاه وفي مقدمتهم الفقهاء الالمـان الى تصوير نظريـة

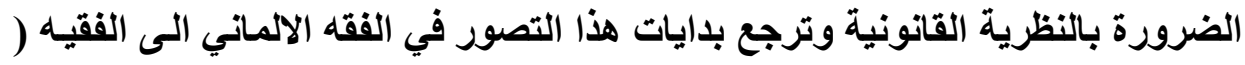
هيجل) وفكرتـه عن سيادة الدولـة والتي هي" اي هذه الفكرة "تطبيق لمقولـة الفقيه

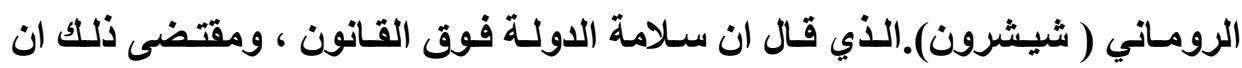

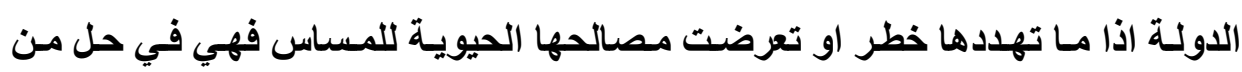
الالتزام بأي قاعدة او قيد لانها في سبيل حماية كيانها والحفاظ على مصالحها يبدو من حقها، بل من واجبها اتخاذ كل مـا هو لازم من اجراعات في سبيل الحفاظ على بقائها واستمرارها، وترتيبا على ذلك فأن الدولة وهي تمـارس هذا الحق فـأن تصرفها يعتبر هن هن

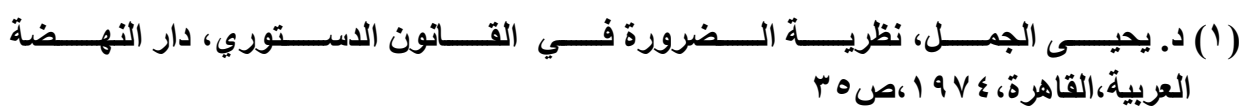

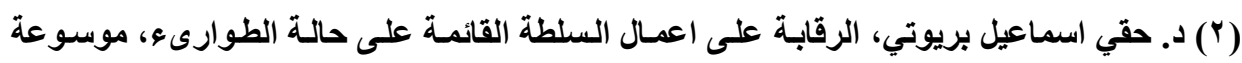

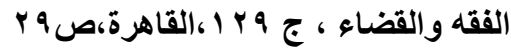


مشروعا حتى لو خالفت القواعد القانونيـة لان ارادة الدولـة ضمن هذا المفهوم هي القانون(')، ويترتب على اعتبار نظرية الضرورة نظرية قانونية ان الاعمال والاجراءات التي تتخذها الدولة في احوال الضرورة هي اجراءات مشروعة ولا تترتب مسؤولية

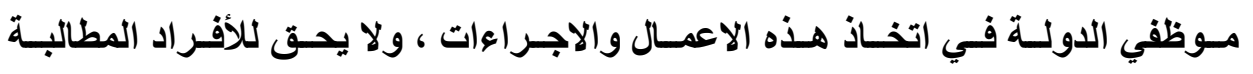
بالتعويض عما يلحقهم من ضرر من جراء ذلك. (r)

\section{الاملب الثاني}

\section{التنظيم القانوني لهالة الطوارىs}

أن الأساس القانوني لحالة الطوارئ لا نجده فقط في الاساتير الوطنية إنما نجده أيضاً في التشريعات والأنظمة او اللوائح ( والقرارات الإداريـة التنظيمية )، والقانون الاستوري هو القانون الأساسي للاولة ، فهو الذي يضع الأسس التي تقوم عليها

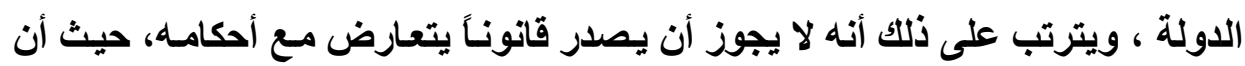
كل قانون آخر غيره يعتبر أدنى منـه في المرتبة ، ومن ثم لا يمكن مخالفته ، ويضع

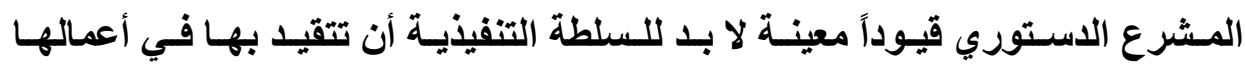
وتصرفاتها وكذلك على السلطة التشريعية عند وضعها التشريعات يجب أن تتوافق مـع هذا القانون الأعلى، ومن الحريـات والحقوق مـا هو مطلق بطبيعة الحسال ، ومن ثم لا

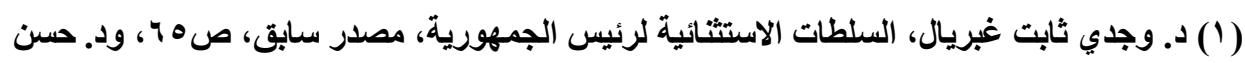

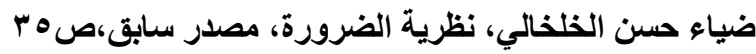

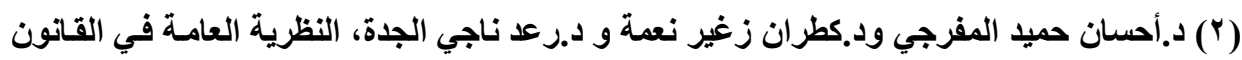

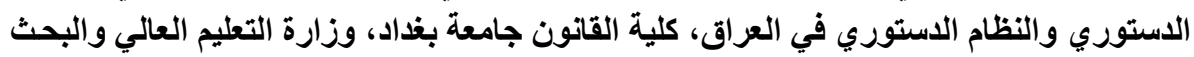

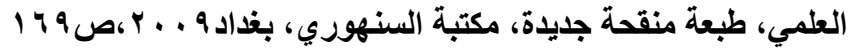


تقبـل التقيـــ أو التظظيم فلـو صـدر تشريع يقيدها كـان هذا التشريع بـاطلاً لمخالفتـه النصوص التشريعية(') بحيث يجب على القانون أن لا يمس هذه المبـادئ التي رغب

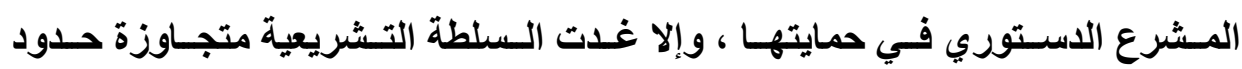
اختصاصها ووجب الحكم بعدم دستوريتها وبطلانها ، وهذا البطلان قد تقرره بعض الاساتير في صلب نصوصها وبما أن نصوص قوانين الطوارئ التي تتعارض مع ما هو وارد في الدستور وخاصة فيما يتعلق ببيان الحقوق والحريات الأساسية للأفراد ، لذلك

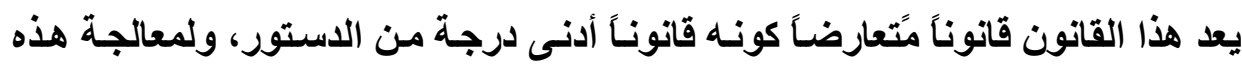

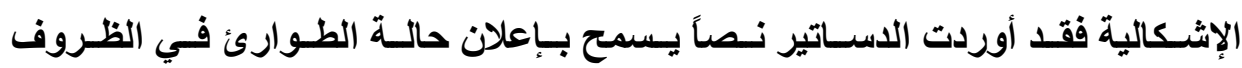
الاستثنائية وذلك بثكل مؤقت للتغلب على هذه الإشكالية على الرغم من أن إعلان حالة الطوارئ يعمل على تحديد الحريات وذلك من أجل السيطرة على الأوضساع والمحافظة على الأمن والاستقرار للاولة ، وأتت فكرة قوانين الطوارئ من مبدأ الضرورة حيث وجد الدستور أصلاً لحماية الحقوق والحريات ومصالح الشعب ، فباذذا مـا وجد مـا يهدد مئد هذه الحقوق والمصالح وأصبح الدستور غير قادر على درأ هذه المخـاطر ، هنـا تتحقق

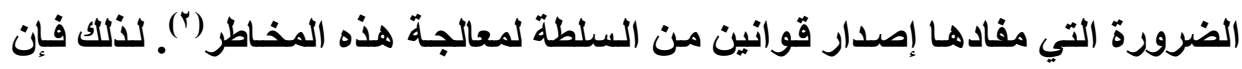
الأساس القانوني لنظام الطوارئ يتمثل في نظرية الضرورة التي تتيح للسلطة الإداريـة القائمة على حالة الطوارئ عند تحقق الظروف الاستثنائية التي أوجبث اللجوء إلى هذا النظام سلطات استثنائية واسعة لمواجهة هذه الظروف(") ،وسنتناول هذا المطلب في

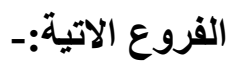

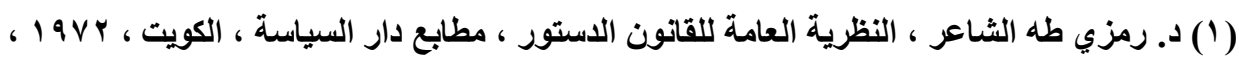




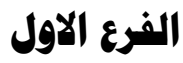

\section{التنظيم الدستوري لحالة الطوارى في هصر}

جـاء في دستور مصر لسنة ؛ 1 ـ ب النافذ الآتـي ( يعلن رئسيس الجمهوريـة بعد أخذ رأي مجلس الوزراء حالـة الطوارئ على النحو الذي ينظمه القانون ويجب عرض هذا الإعلان على مجلس النواب خلال الآيام السبعة التالية ليقرر مـا يراه بشأنه وإذا حدث الإعلان في غير دور الإنعقـاد العـادي وجب دعوة المجلس للإنعقـاد فوراً

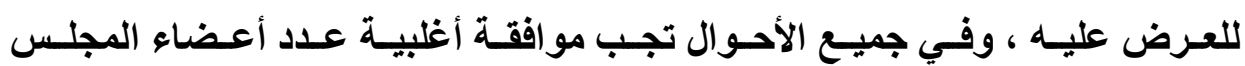
على إعلان حالة الطوارئ ويكون إعلانها لمدة محددة لا تتجاوز ثلاثة أشهر ولا تمد إلا لمدة أخرى مماثلة بعد موافقة ثلثي أعضاء المجلس وإذا كان المجلس غير قائم يعرض لهان الامر على مجلس الوزراء للموافقة على أن يعرض على مجلس النواب الجديد في المي إجتماع لله ولا يجوز حل مجلس النواب أثناء سريان حالة الطوارئ )(') ، كذلك جاء في الاسـتور المـصري الآتـي ( إذا حـث في غيـر دور إنعقـاد مجلس النـواب مــا يوجب الإسراع في إتخـاذ تدابير لا تحتمل التأخير يـعو رئيس الجمهوريـة المجلس لإنعقـاد طارئ لعرض الأمر عليه وإذا كـان مجلس النواب غير قائم يجوز لرئيس الجمهوريـة إصدار قرارات بقوانين على أن يتم عرضـها ومناقشتها والمواققة عليها خلال خمسة عشر يوماً من إنعقاد المجلس الجديد فإذا لم تعرض وتتـاقش أو إذا عرضت ولم يقرها المجلس زال بأثر رجعي ما كان لها من قوة القانون دون الحاجة إلى إصدار قرار بذلك إلا إذا رأى المجلس إعتمـاد ونفاذهـا في الترة السابقة أو تسوية مـا ترتب عليها من 
أما بالنسبة للفقه المصري فيكاد يجمع على الأخذ بالتصور القانوني لنظريـة

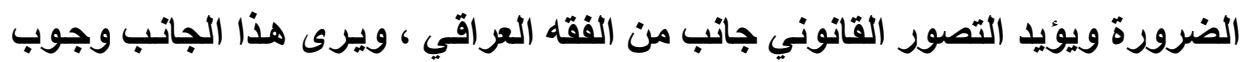

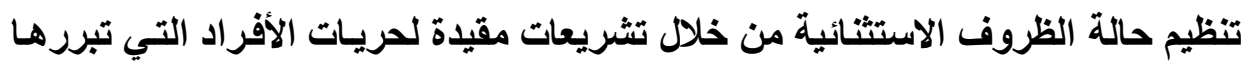

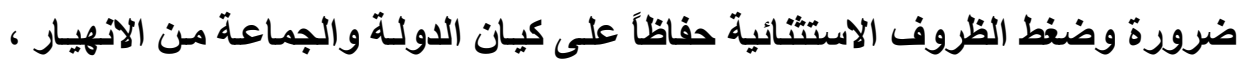
ويترتب على هذا التصور القانوني لنظرية الضرورة أن تعد جميع الإجراءات التي لإني

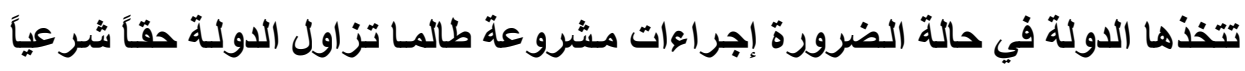

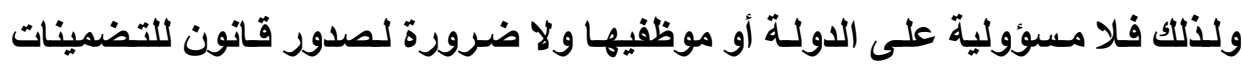

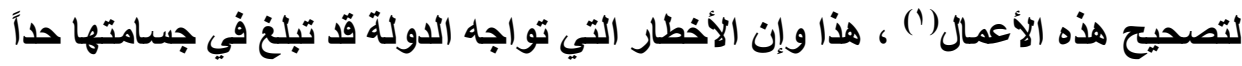

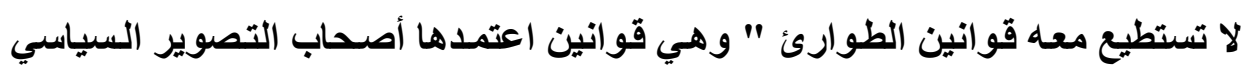

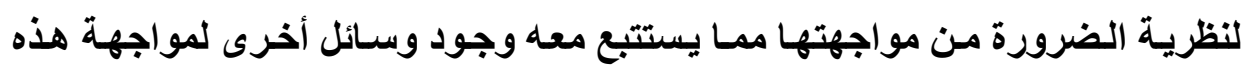

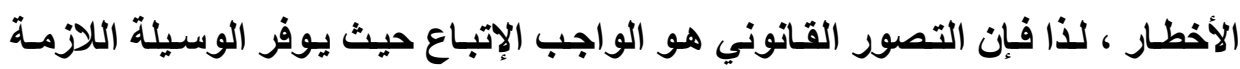

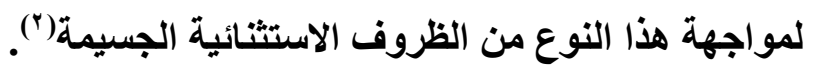

\section{الفرع الثاني}

\section{التنظيه الدستوري لحالة الطوارى في العراق}

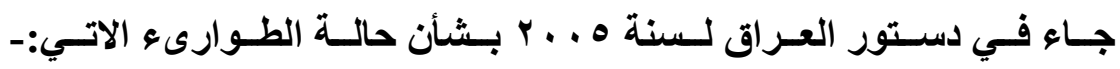

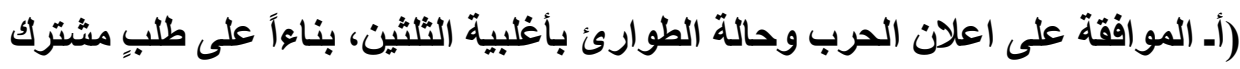

(1) د.محمد علـي ال ياسين ، القـانون الإداري ،المكتبـة الحديثة ،بدون تساريخ، بيروت ، لبنـان ،

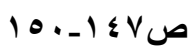

(ץ) كاظم علي الجنابي ، سلطات رئيس الدولة التثريعية في ظل الظروف الاستثائية ، دراسة مقارنة،

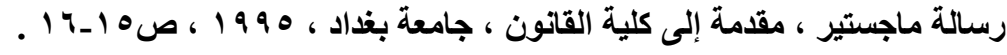


مـن رئسيس الجمهوريـة، ورئسيس مجلس الـوزراء. ب ـ ـتُعلـن حالـة الطـوارئ لمـدة

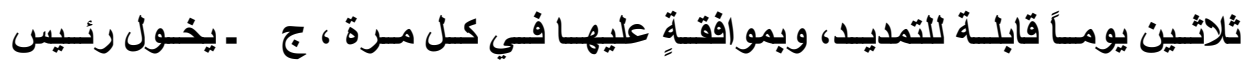
مجلس الوزراء الصلاحيات اللازمـة التي تمكنه من ادارة شؤون البلاد في اثــاء مدة اعلان الحرب وحالـة الطوارئ، وتنظم هذه الصلاحيات بقـانون، بمـا لا يتعـارض مـع الاستور ، دـ ـ يعرض رئيس مجلس الوزراء على مجلس النواب، الاجراءات المتخذة

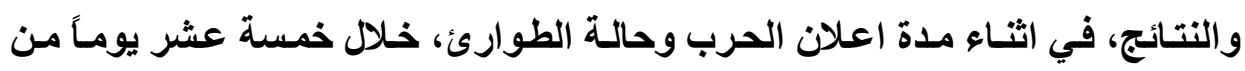
تـاريخ انتهائها) (') ، وكـلكت نظمـت حالـة الطوارئ في الاسـاتير السابقة حيث صدر

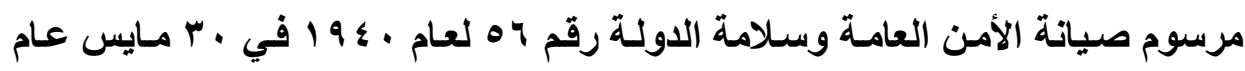

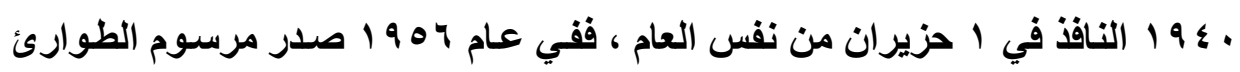
رقم 1 ، ومن ثم قانون السلامة الوطنية رقم ع لعام هو 197 ، وبعد الاحتلال الأمريكي صدر عـام ع . . ب قـانون الدفاع والسلامة الوطنيـة العراقي رقم ا النافذ في الوقت الحاضر. 


\section{المبحث الثالث}

\section{القواعد العاهة لهالة الطوارئ وشروطها}

وستتاول في هذا المبحث القواعد العامـة لحالة الطوارئ من خلال اسبابها

$$
\text { وشروطها في المطالب الآتية: }
$$

\section{المطاب الأول}

\section{الأسباب المبررة لحالة الطوارئ}

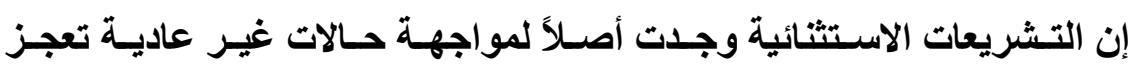

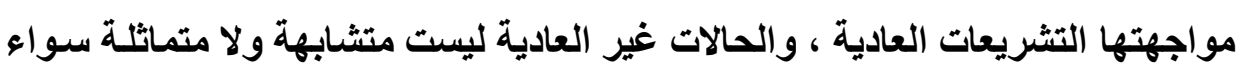

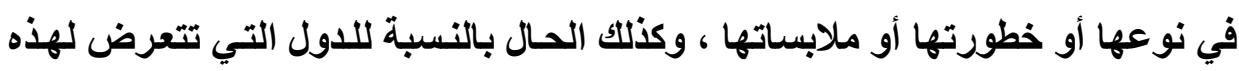

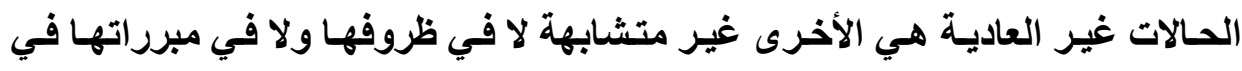

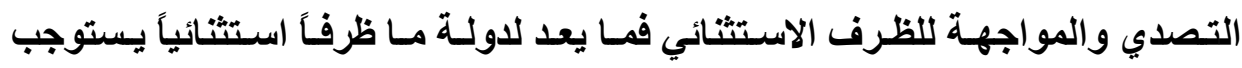

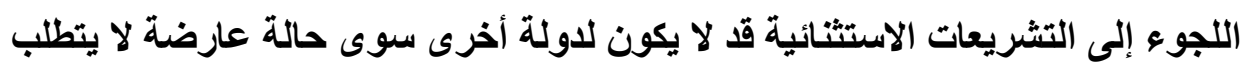

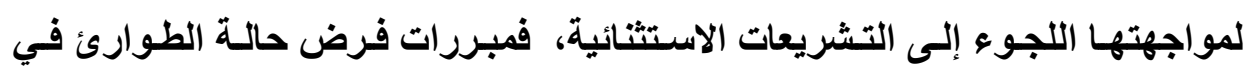
القانون المقارن تمثل عنصرين أساسيين : الأولى أن يحدث بالدولة خطر نتيجة الحرب أو الغزو أو الاضطرابات أو تهايد الأمن

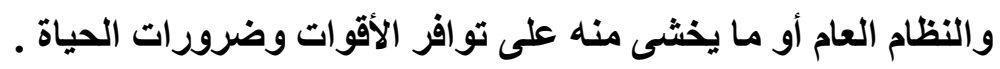


الثاني : أن يبلغ هذا الخطر درجة الجسامة التي تجعل من السلطة العامة بمـا لها من

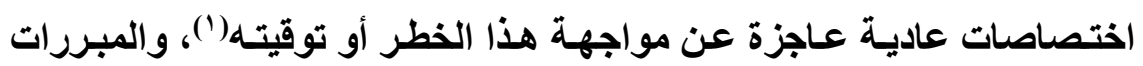

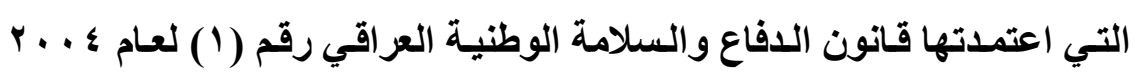
لإعلان حالـة الطوارئ حيث أجـاز لرئيس الـوزراء بعد موافقـة هيئة الرئساسـة بالإجماع إعلان حالة الطوارئ بسبب وجود خطر جسيم يهدد حياة الأفراد نتيجة

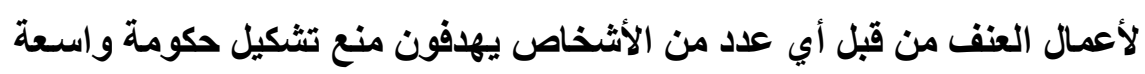

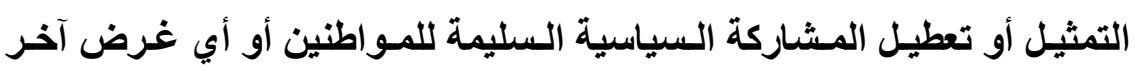
(م 1 ) وشرع هذا القانون في ظروف غاية في الصعوبة يمر بها العراق ، وقد صدر قبل انتخاب ؛ . . ب فاقتصر سبب إعلان حالة الطوارئ على أعمال العنف لمنع تثكيل الحكومة أو تعطيل مشاركة المواطنين في العملية السياسية(؟) فهذا القانون في نصه لهذه الأسباب قد أظهر النيـة التي كاتت تراود واضعي هذا القانون هو تثبيت النظام والعملية السياسية التي كانت حديثة النشأة في ذلتك الوقت ، وهنـا يتــاقض والأسس التي تقوم عليه مبررات إعلان الطوارئ في الدول الأخرى ، ويمكن إجمالها في القواعد التالية :-

أولا - أسباب أو مبررات خارجية وهي حالة وقهع المرب أو التهديد بها : لا يوجد تعريف محدد للحرب. ومـن التعساريف التـي تبين العناصـر القانونيـة للحرب هو تعريف لآحد فقهاء القـانون إذ عرف الحرب بأنها " صراع مسلح غير محدود من حيث الزمان والمكان ووسائل القتال بين دولتين أو أكثر يسعى كل طرف إلى

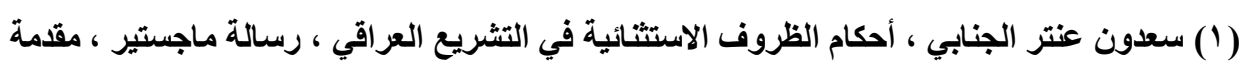

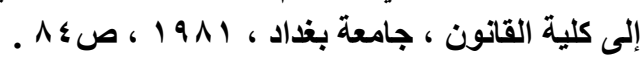

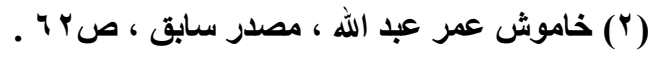


فرض إرادته على الطرف الآخر لتحقيق مصلحته المرجوة "('). ويلاحظ أن الدول التي أخذت بهذا السبب مبكراً لإعلان حالة الطوارئ استخدمت ألفاظ وعبارات مرنـة

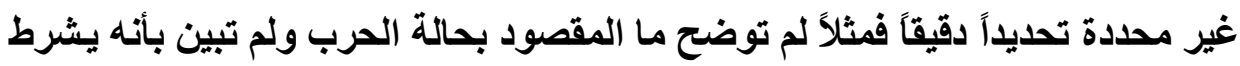

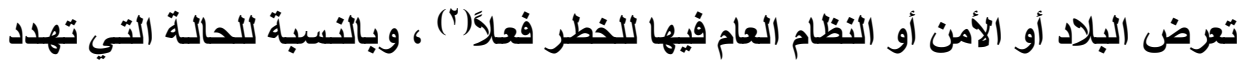

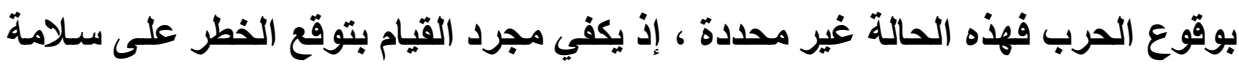

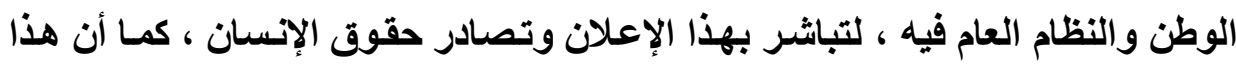

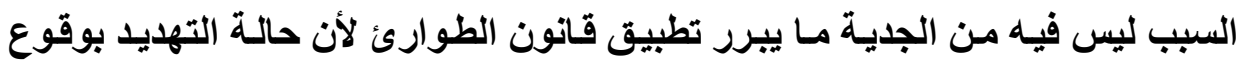

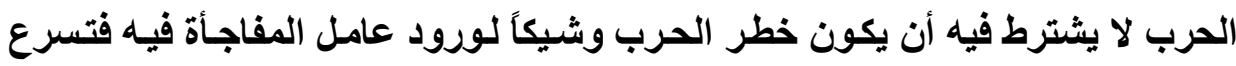

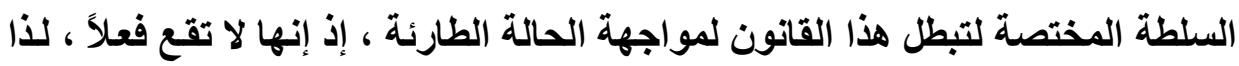

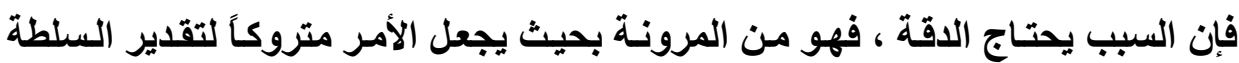
المختصة بإعلان حالة الطوارئ (").

\section{ثانيًا- أسباب أو هبررات داخلية حدوث اضطرابات أو أعمال عنف :}

إن تحديد الاضطرابات ونوعيتها أمر صعب التحديد فهي تعني العصيان أو

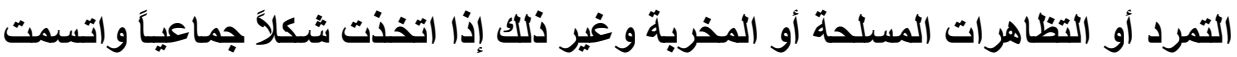
بمظهر العنف وتفاقم حظر هـا بحيث لم تعد السلطة التنفيذية قادرة على مواجهتها بوسائلها العادية(") ، وتتذرع السلطات بحق سن تثريعات ضد أعمال العنف والتخريب

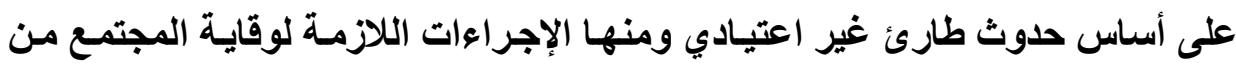
(1) د. عامر الجومرد ، المعاهدات في ظل الفصل السابع من ميثاق الأمم المتحدة ، مجلة الرافدين

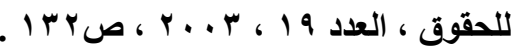

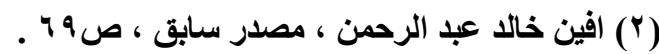

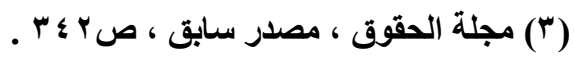

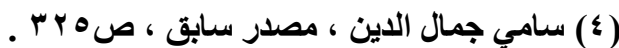


الإرهاب(') ، ومصطلح الإرهاب مصطلح أخذ يستعمل في الآونـة الأخيرة بشكل واسـع وهـو يـشمل أعمـال العنف والاضـر ابات وأعمـال التخريـب وغير ذلتك وأصبح هـا المصطلح من الأمور التي تهدد الأمن والاستقرار في دول كثيرة من العالم ، أما بالنسبة لتعريفـه فإنـه لا يوجد تعريف متفق عليه وقد وردت عدة تعريفـات بهذا الصدد لهذا المصطلح ، فعرفها بعضهم الإرهاب " هي عمليات استخدام العنف والتهديد بقصد بث الأعر بين الناس وتحقيق أهداف لا يمكن الحصول عليها بالوسـائل القانونية والسلمية

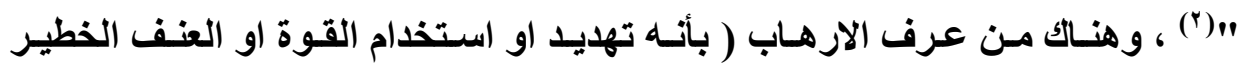
للقضاء على سياسة او دين ) (") .

\section{الاطلب الثاني}

\section{الشروط الهاجب توافرها لإعلان حالة الطوارئ}

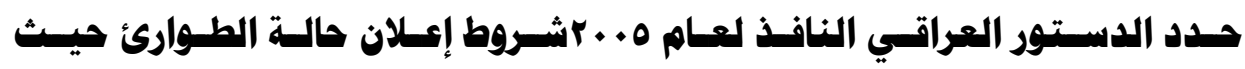

( أـ الموافقة على اعلان الحرب وحالـة الطوارئ بأغلبية الثثين ، بنـاءاً على

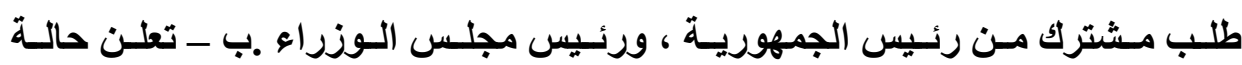
الطوارئ لمدة ثلاثين يوماً قابلة للتمديد ، وبموافقة عليها في كل مرة .ج - يخول رئيس ، ئيس مجلس الوزراء الصلاحيات اللازمة التي تمكنه من إدارة شؤون البلاد خلال مدة إعلان

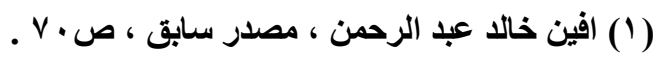

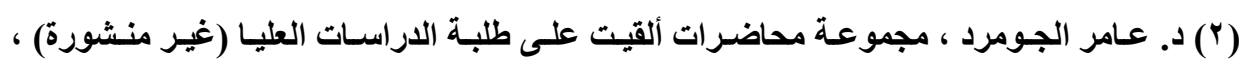

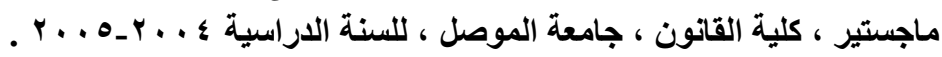

(3) joun mealdowney - human right in tr ansition • printed in Germany 2003 .p. 138 
حالة الطوارئ وتنظم هذه الصلاحيات بقانون بما لا يتعارض مـع الاستور .د - يعرض رئيس مجلس الوزراء على مجلس النواب ، الإجراءات المتخذة والنتائج ، خلال مدة

إعلان الحرب وحالة الطوارئ ، خلال خمسة عشر يوماً من تاريخ انتهائها ) ('). إن القانون الناقذ في العراق والذي يتتاول موضوع الطوارئ هو قانون الدفاع

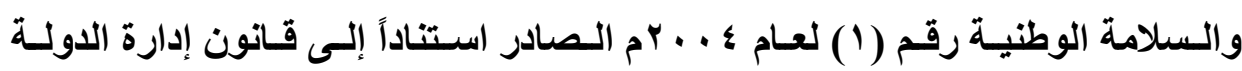

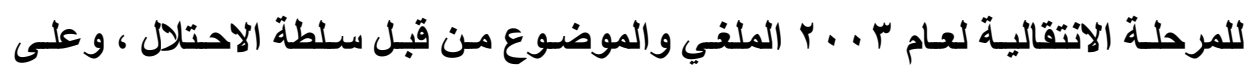
الرغم من صدور دستور جديد الذي تم الاستفتاء عليه عام ه . . ب فإن القانون المستتد

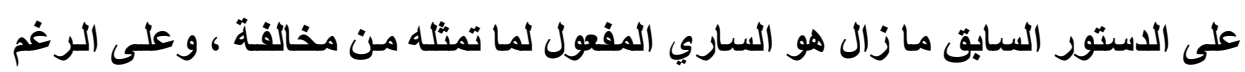

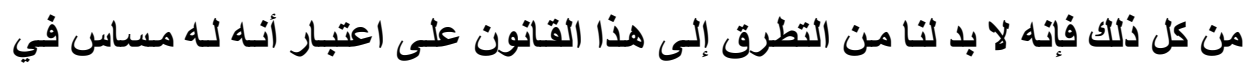
حقوق وحريات الأفراد لما يعيثه الثعب العراقي من ظروف استثنائية كما ذكرنا سـابقاً فقد صدر هذا القانون استناداً إلى قانون إدارة الدولة للمرحلة الانتقالية واستناداً إلى أحكام القسم الثاني من حملته هذا القانون والمادة (ه Y) من القانون إعلان فوفقاً لهذا القانون يكون إعلان حالة الطوارئ عند توافر الأسباب الآتية () : ا - عند وجود خطر جسيم وحال يهدد حياة الأفراد .

r- أن يكون ناثــاً عن حملـة مستمرة لمنـع تشكيل حكومـة أو تعطيل المشاركة

$$
\text { السلمية في الحكم. }
$$

و في مصر فقد جـاء في قـانون حالـة الطوارئ على أنسه ( يجوز إعلان حالـة الطوارئ كلما تعرض الأمن أو النظام العـام في أراضـي الجمهوريـة أو في منطقة منهـا 
للخطر سـواء أكسان ذلك بسبب وقوع حرب أو قيسام حالـة تهدد بوقوعها أو حدوث اضطر ابات في الـاخل أو كوارث عامـة أو انتشار وبـاء )(') فوفق هذا القانون فِان الحالات التي تجيز إعلان حالة الطوارئ هي() :

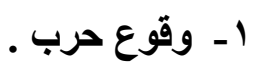

r- قيام حالة تهدد بوقوع حرب . r- - مدوث اضطر ابات داخلية. ع - مدوث كوارث عامة .

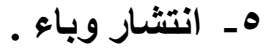




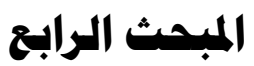 \\ هاهية الهقوق المدنية وانواعها وأثر إعلان حالة الطوارئ عليها}

سنتناول في هذا المبحث مفهوم الحقوق المدنية وانواعها وأثر حالة الطوارئ

عليها من خلال المطالب الاتية: - - مسئ

\section{المطاب الأول \\ هفهوم المقوق المدنية}

ويقصد بالحقوق المدنية الحياتية ويسميها البعض الحقوق اللصيقة بشخص

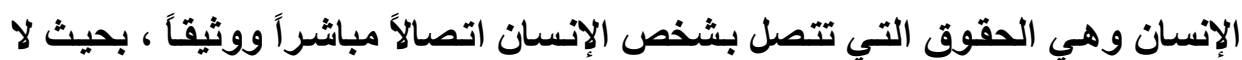

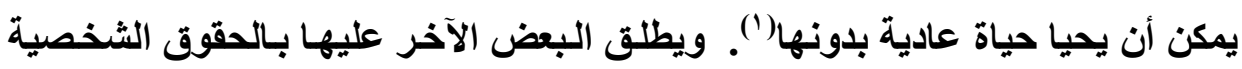

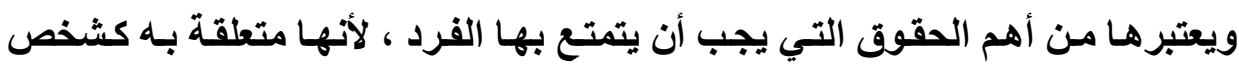

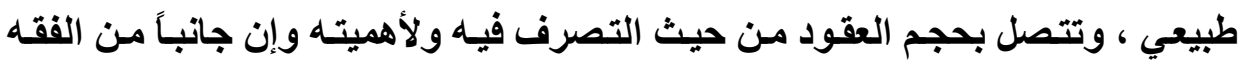

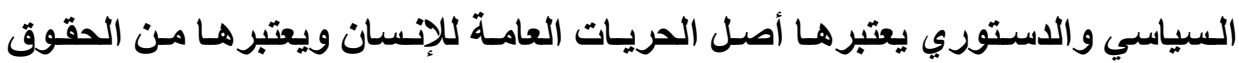

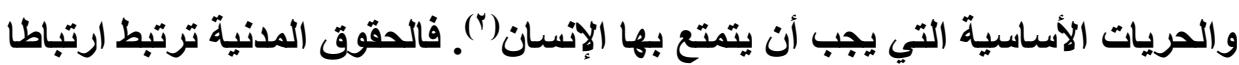

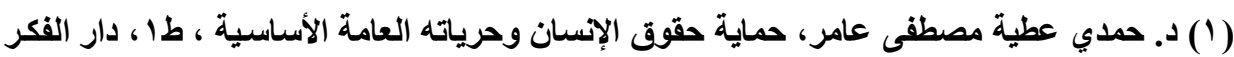

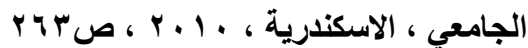

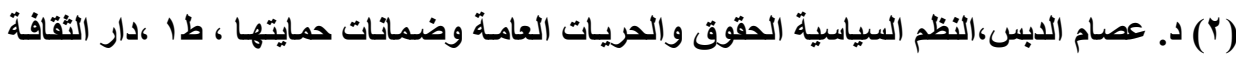

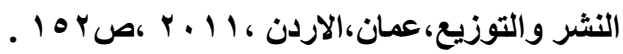

mark v.t aushnet-making civil right law-thurgood-marshall-naacp legal de fensefund oxford $-1993-p$ (pre face ) 
وثيقا بالإنسان فهذه الحقوق تمهـ الطريق للإنسان لمزاولة حقوق أخرى سواء كانت

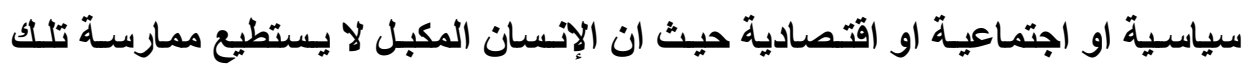

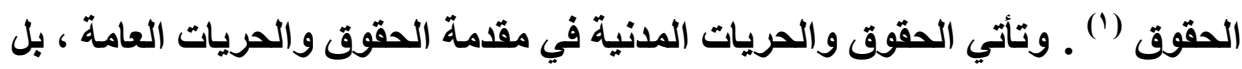

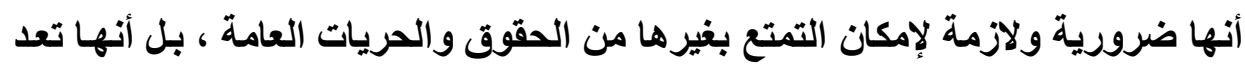

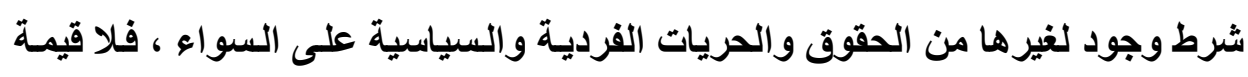

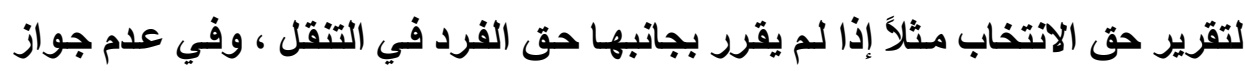

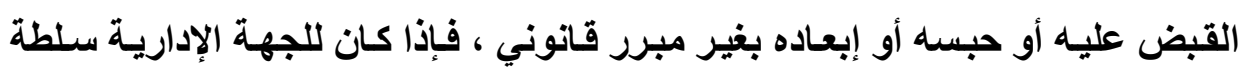

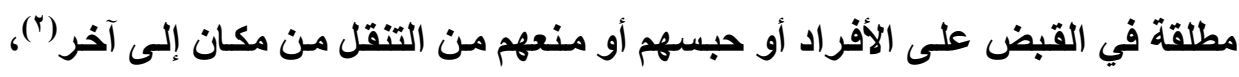

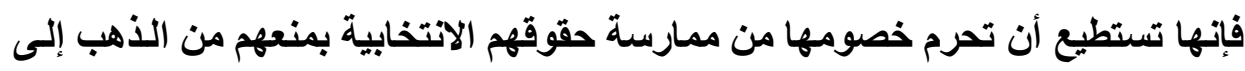

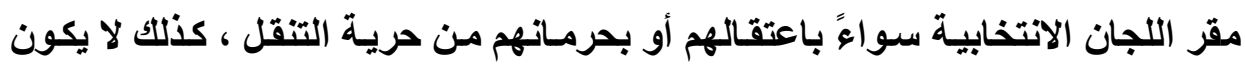

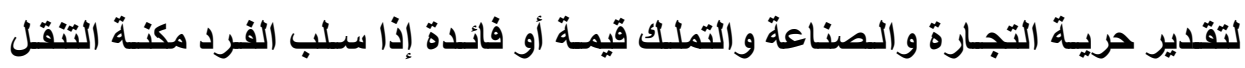

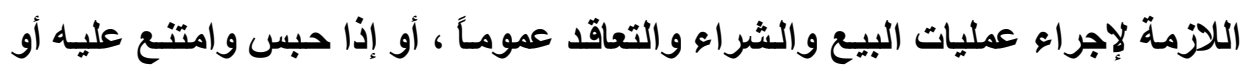

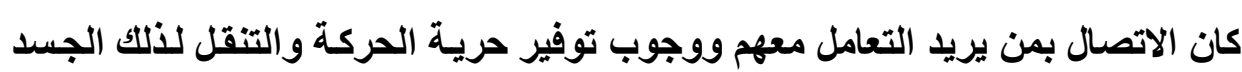

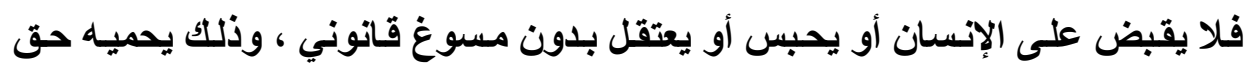

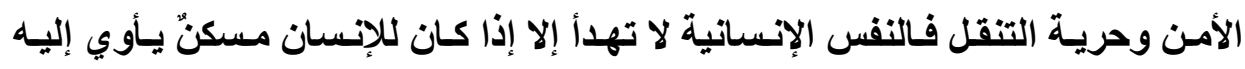

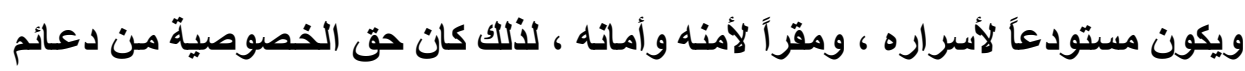

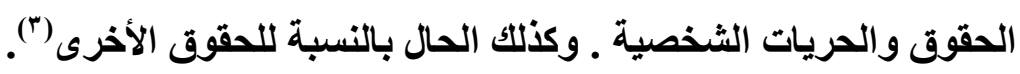

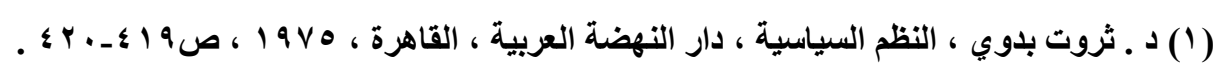

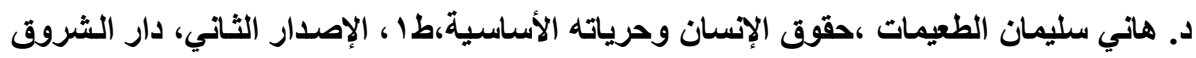

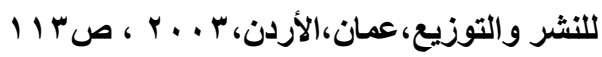

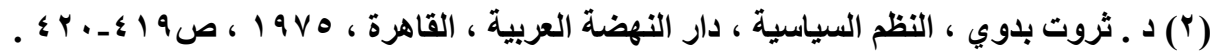

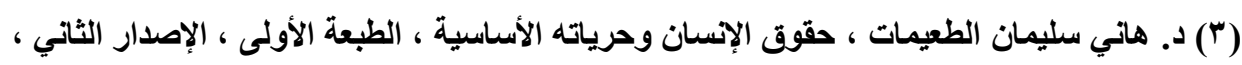

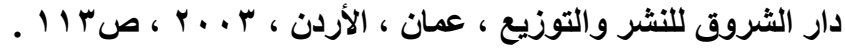




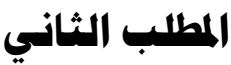

\section{أنواع الهقوق المدنية وأثر حالة الطوارئ عليها}

\section{وسنتناول في هذا المطلب أنواع الحقوق المدنية في الآتي :- \\ أولاً / الحق في الحياة وأثر حالة الطوارئ عليه.}

من المعتقات التي أصبحت راسخة في أذهـان البشرية أن الله سبحانه وتعالى هو واهب نعمة الحياة للإنسان ، فالإنسان لا يكون إلا إذا خلقه الله تعالى وأعطاه الروح والحياة ، قال تعالى : \}فإذا سـويته ونفخت فيه من روحي فقعوا لـه سـاجدين\{ وبعده يأتي في دور الإنسان في أن يعيش حياته كاملة . وحق الحياة في الظاهر هو حق للإنسان ، لكنه في الحقيقة منحة من الله تعالى ، وليس للإنسان فضل في إيجـاده(')، وتتكفل قوانين العقوبـات عادة بحمايـة هذا الحق وتنظيمه ، والقاعدة الأساسية في كل مجتمع هو عدم استخدام العنف ضد حياة الآخرين إلا في حالات الدفاع الثرعي عن النفس والعرض والمـال ، ومـع ذلك فِإن انتهاك هذا الحيـاة فـي الوقـت الـراهن يأخـــ صسوراً ومظـاهر متعـدة أهمهـا التصفية والاغتيـال والاختطف والاختفاء القسري أو اللاإرادي على يد الأجهزة الأمنية والقمية في الدول

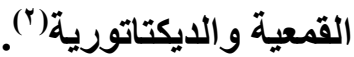

أمسا بالنسبة للتنظيم القـانوني لحق الحيـاة حيث تبـدو القيمـة القانونيـة لإدراج الحقوق والحريـات العامـة في نصوص الدسـتير أن حمايـة الحقوق والحريـات العامـة للأفراد تأخذ ذات القيمـة القانونيـة للنصوص التي وردت فيها ، وتصبح لهذا الحقوق 
والحريات القيمة القانونية نفسها التي يتمتع بها الدستور ، وتكون لها قاسـة أحكام الاستور نفسه(') ، وقد أخذ المشرع العراقي لعام ه . . . سـوعاً الاستوري أو العادي بالقواعد العامة المتعلقة بحق الحياة واعتبره مقداً لا يجوز المساس والاعتداء عليه

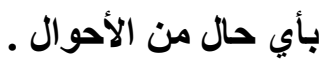

وجـاء في الاستور العراقي لسنة هـ ـ. ب م ان " لكل فـرد الحق في الحيـاة والأمن والحرية ولا يجوز الحرمان من هذه الحقوق أو تقيدها إلا وفقاً للقانون ، وبنـاءً

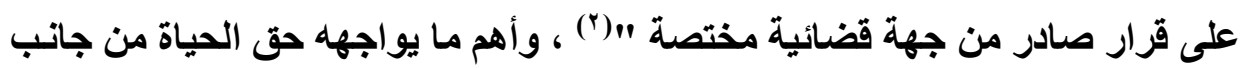
السلطات العامـة هي عقوبـة الإعدام وقد بلـغ في عـام . . . ب عدد الدول التـي ألغت

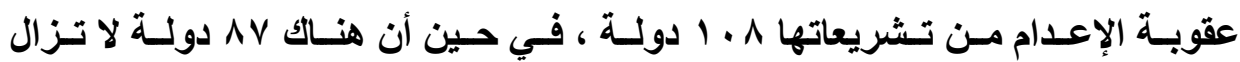
تمارسها، ومنها الصين والولايات المتحدة والعراق والكثير من دول العالم الثالث(ّاّ. وهذا الحق في الوقت الراهن في العراق من أكثر الحقوق التي تتعرض للانتهاك

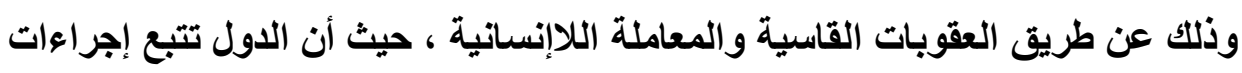
في ظل حالـة الطوارئ (مسن سـوء معاملـة والتعذيب للمعتقلين داخل السجون بـافع إجبارهم على الاعتر اف كما قد يؤدي إلى وفاة الكثير منهم تحت التعذيب ، لذا فإن هذا الحق يتأثر سلباً في ظل قانون الطوارئ وحدوث حالات الوفـاة العديدة في السجون وأماكن الاحتجاز متذرعة بشتى الأسباب وبحجة الإرهاب) (؛).

( ) د. حمـدي عطيـة بكر عـامر، حمايـة حقوق الإنسان وحرياتهـ العامـة الأساسية، مصدر سـابق،

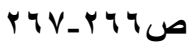

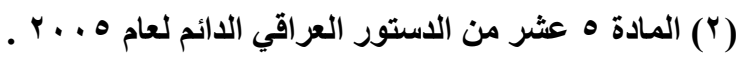

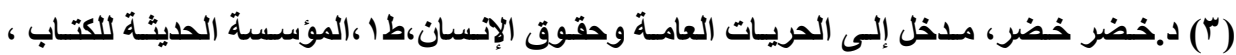

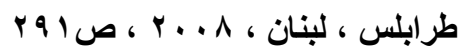

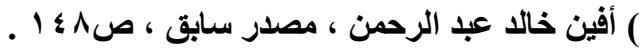




\section{أثر حالة الطوارئ على حق الإنسان في الحياة}

إن المتتبع للأحكام التي جاعت بها الثريعة الإسـلامية لكفالـة حق الحيـاة يجدها

من الثمول والإحاطة إلى المدى الأي يتفق مع أهمية هذا الحق باعتباره أثمن ما يملكه الإنسان في الوجود ، وباعتبار ما له من أثر في حفظ كيان المجتمع وحيويته وتماسكه من جهة أخرى(') ، ويعد حق الحياة من أولى الحقوق التي يتمتع بها الإنسان فلا يجوز حرمانه من حقه في الحياة إلا طبقاً لمـا يقتضيه القانون والمصلحة العامـة وبعد إتمـام الإجراءات والضمانات كافة التي تنص عليها القوانين وهذا الحق يتمتع الجميع دون تميز بين الصغير والكبيز والمـرأة والرجل أو الغنـي والفقير (؟). إن حق الإنسان في الحياة هو أسمى الحقوق ، بل هو أساسها جميعاً إذ لا يعقل التفكير في ممارسة أي حق هق آخر دون ضمان أولي وحماية كافية لهذا الحق المتأصل في الإنسان ، وهذا الحق يجب لهب ضمانه وحمايته أولاً بنص القانون وثانياً من خلال التطبيق(")، وهذا يعني وجوب قيام السلطات المختصة باتخـاذ الإجـراءات الإيجابيـة لخلق الأمسان والاطمئنسان في نفس المواطن وحمايته من فقدان حياته ، أي حمايته ليس فقط من عدوان الآخرين فحسب الآبراب بـل كذلكك من سـوء استعمال السلطة وبخاصـة من جانب الأجهزة الأمنية ، كالشرطة والقوات المسلحة ، الأمر الأي يوجب مراقبة الجهات القانونية لتصرفات رجال الأمن

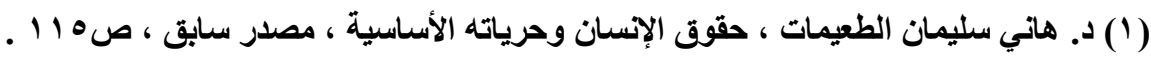

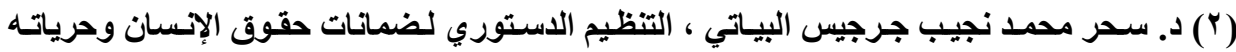

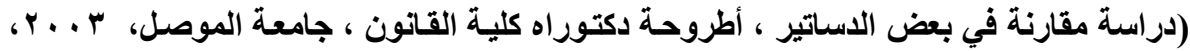


وتقيد الظروف التي يجوز فيها لمثل هذه السلطات أن تحرم الإنسان من حياته(') ، لهذا كان لا بد من وضع قيود صارمة ورقابة فعالة على هذه الأجهزة والسلطات في الدول

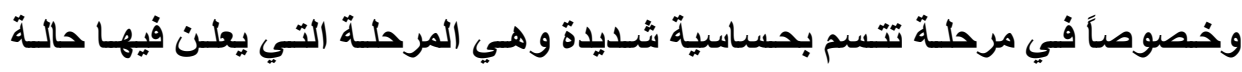

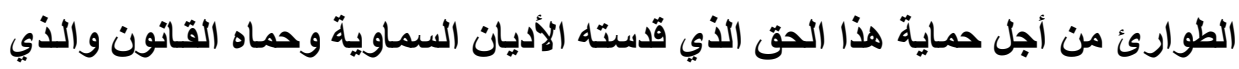
يعد الركيزة الأساسية لكل الحقوق الأخرى حيث لا يمكن تصور حقوق في حالة فقدان

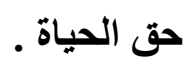

وفي ردنا على التساؤل الذي طرحنـاه في اشكالية البحث حول نجاح السلطات

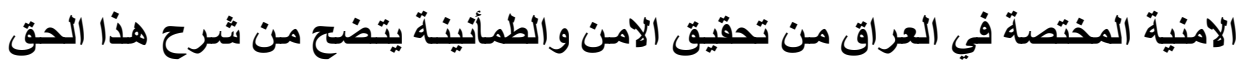

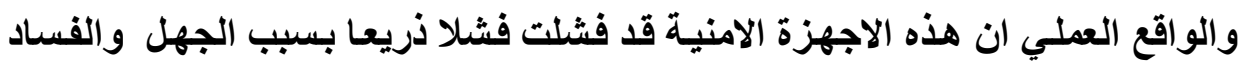

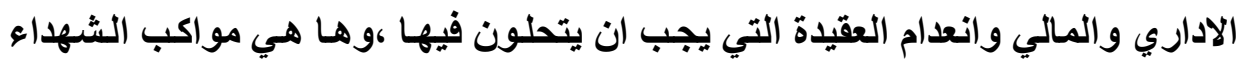

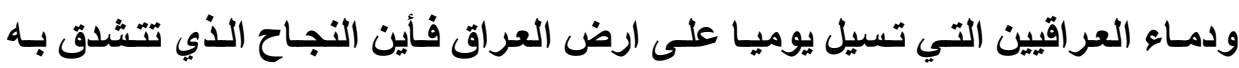

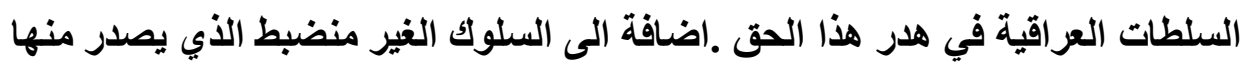

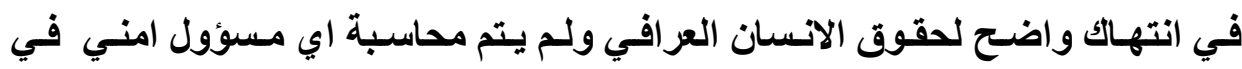

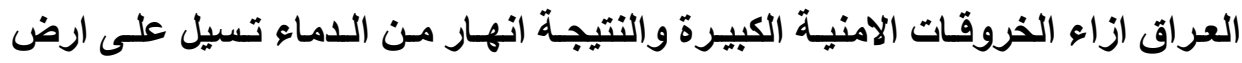

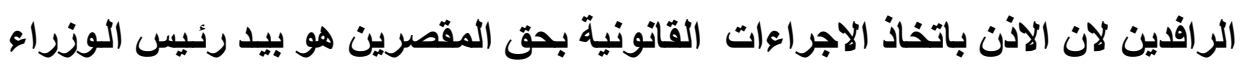

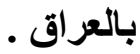

أمسا بالنسبة لعقوبة الإعدام فإنها لا يجوز فرضها إلا في أكثر الجرائم خطورة

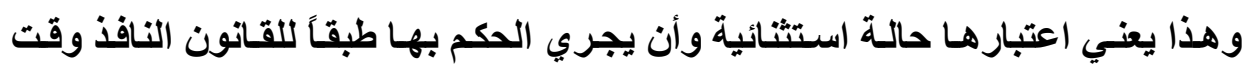

(1) د. ثناء فؤاد عبد الله ، خصوصية طرح الديمقراطية في الواقع العربي ، سلسلة كتب المستقبل

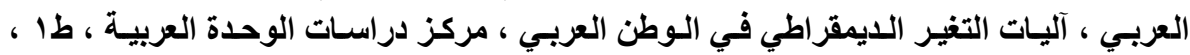


ارتكاب الجريمة فحسب وشرط التقيد بمنح الضمانات الإجرائية ، بما في ذلك الحق في

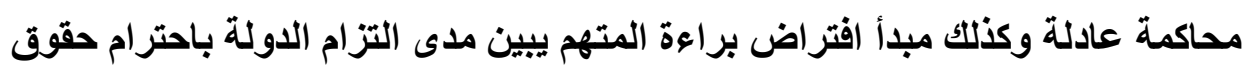

الإنسان ومن بينها حق المتهم (')

\section{ثانيًا : حق السلاهة الشخصية وأثر حالة الطوارئ عليها.}

هذا الحق انعكاس للحق الأول فلا يجوز إلقاء القبض على أحد أو اعتقاله أو

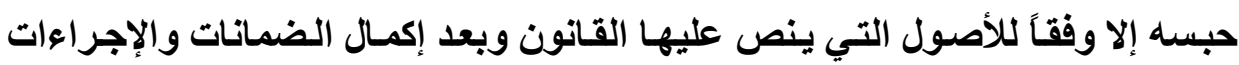
التي ينص عليها القانون ويتفرع عن هذا الحق حق آخر يتمثل بعدم جواز تعريض أحد

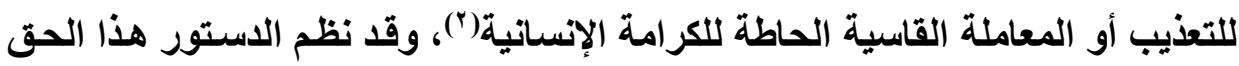
باعتباره من الحقوق الاستورية نظرياً ، لكن من الناحية الواقعية يلحظ على هذا الحق أنـه منتهك في كثير مـن دول العـالم وبالذات دول العـالم الثالث ، بحجـة حمايـة الأمسن والنظام وتحقيق الاستقرار .

فقد نص الاستور العراقي لسنةه . . ب ان" لكل فرد الحق في الحيـاة والأمن والحرية ، ولا يجوز الحرمان من هذه الحقوق أو تقييدها إلا وفقاً للقانون وبنـاءً على قرار صادر عن جهة قضائية مختصة("). وكذلك نص ايضا على أن " حريـة الإنسان وكرامته مصونة ، لا يجوز توقيف أحد أو التحقيق معه إلا بموجب قرار قضائي ، يحرم جميع أنواع التعذيب النفسي والجسدي والمعاملة غير الإنساتية ولا عبرة بـأي اعتراف انتزاع بـالإكراه أو التهديـا أو التعذيب ، وللمتضرر المطالبـة بـالتعويض عن الضرر

(1) سردار علي عزيز، ضمانات المحاكمة العادلة للمتهم(دراسـة مقارنة بالشريعة الإسلامية)، دار

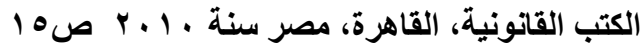

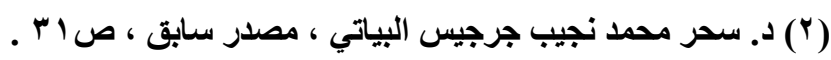

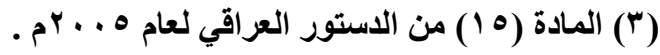


المادي و المعنوي الذي أصابه وفقاً للقانون(') ، أما بالنسبة لقانون الطوارئ في العراق

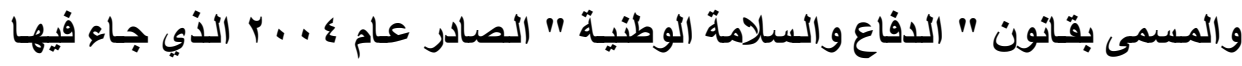

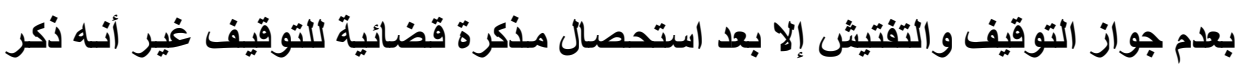

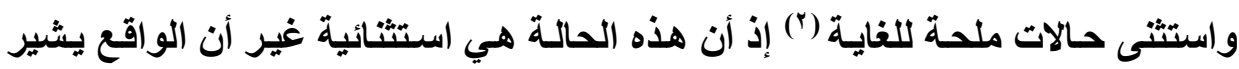

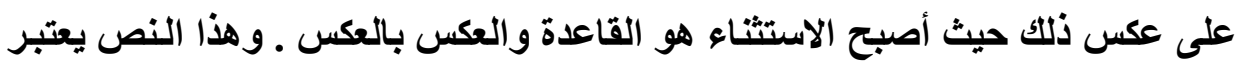

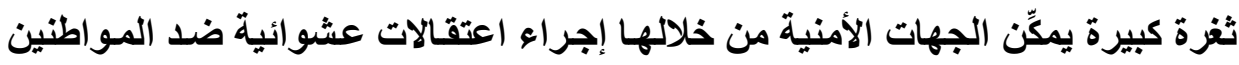
علماً بأن هذا القانون هو الساري بالرغم من صدوره في فترة كانت قانون إدارة الدولية للمرحلة الانتقالية هي النافنة وكما هو معروف فقد صدر هذا القانون ومن قبل قوات التات الاحتلال المسمى " سلطة الاتتلاف " وبعد صدور الدستور الجديد بقي هذا القانون

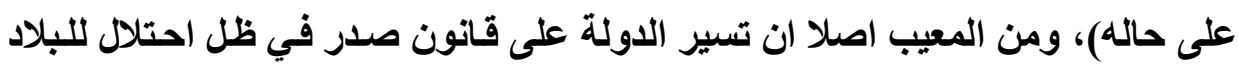

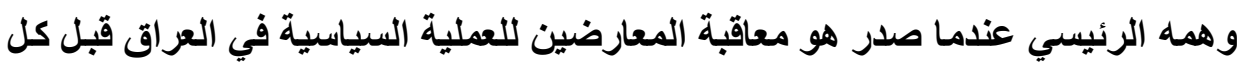

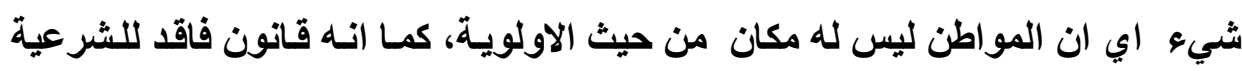

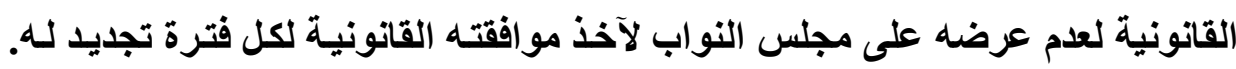

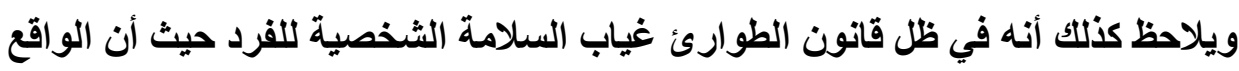

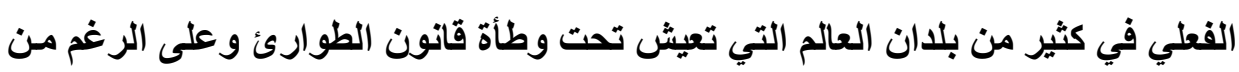

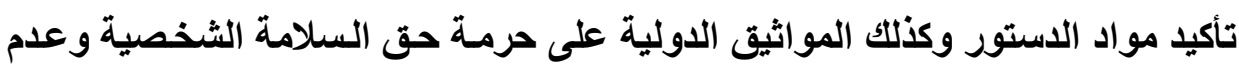

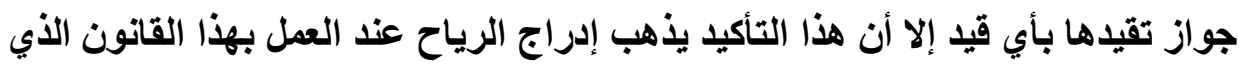

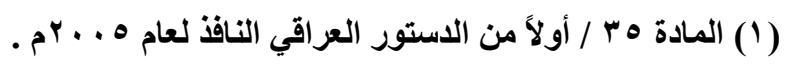

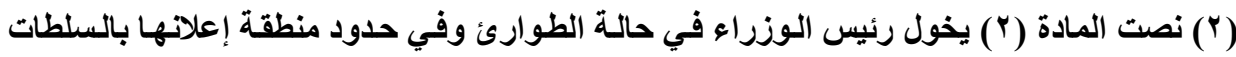

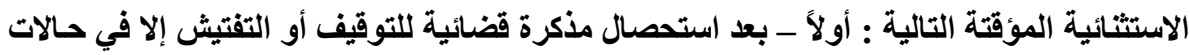

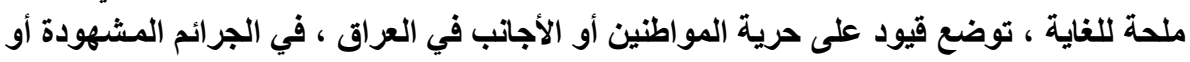

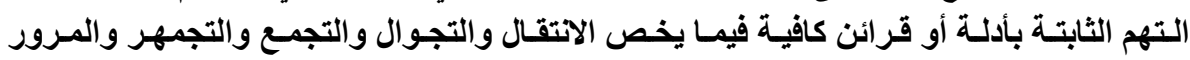


أصبح العمل به هو القاعدة في عدد من الدول والعمل بالتشريعات العادية هو الاستثناء وخير مثال على ذلك هو ما حدث في مصر سابقاً ويحدث في سوريا والعراق التي تعيش

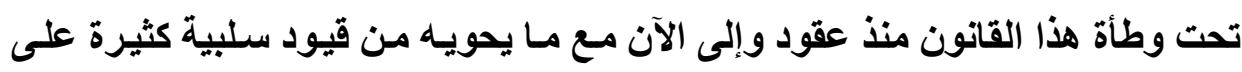
حقوق الإنسان(') - (') - (1)

\section{أثر حالة الطوارئ على حق الإنسان في السلاهة الشخصية.}

مـن أكثر حقوق الإنسان تـأثراً بـإعلان حالـة الطوارئ هـي حق الإنسان في السلامة الثخصية لما تمارسه سلطات الدولة التفيذية من أعمال لها مساس بالسلامة الإسية الشخصية للمواطنين من اعتقالات وتعذيب في السجون وذلك من أجل نزع اعتر افات أو معلومات باستخدام الوسائل اللاإنسانية كافة ـ والواقع في العراق خير دليل على تجاوز

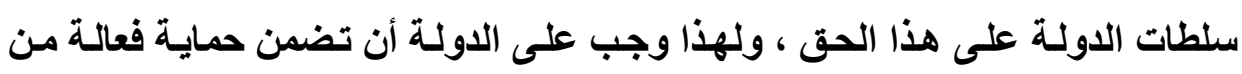
خلال جهاز فعال للرقابة بحيث يمكن إجراء التحقيق الثامل في الشكاوى المقدمة بهذا الخصوص ومعاقبة كل من ثبت عليه المسؤولية وأن تفتح البـاب أمسام المتضرر من اللجوء إلى القضاء والمطالبـة بحقه في التعويض()، وقد مارست الولايـات المتحدة الأمريكيـة أسـاليب مختلفـة تمس السـلامة الثخـصية منهــا التعـيب وظهـرت أولهى التفاصيل عن كيفية قضاء أهم المعتقلين المشتبه بضلوعهم في الإرهاب أيامهم داخل السجون السرية التي كانت تديرها وكالة الاستخبارات المركزية " سي أي إن " خـارج الولايات المتحدة ، فمن بين الأسـاليب المتبعة إجبـار المعتقل على الوقوف وهو شبه

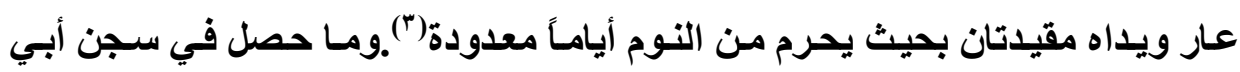

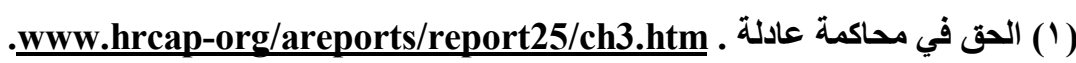

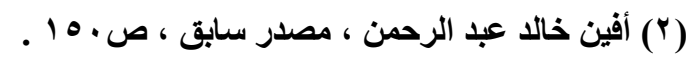

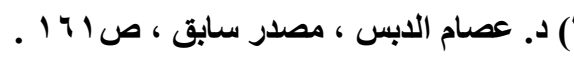


غريب وكذلك مـا يحصل في الوقت الحاضر مـن تعذيب وتنكيل بحق بعض اطيـاف ومكونات شعب العراق ولا ادل على ذلك من تقارير منظمـات حقوق الانسـان المختلفة وسط صمت حكومي شائن من العليات الارهابيـة التي تقوم بها بعض الاجهزة الامنية والمليشيات في العراق ووسط صنت المؤسسة القضائية سواء المحاكم منها او جهاز الادعاء العام بالعراق وبالتالي فقدت هذه المؤسسة استقلاليتها وحيادتها عندما التزمت وجهة النظر الحكومية واعتبرت كل معارض للنهج الحكومي بمنزلـة الارهـاب للتصفية

\section{ثالثًا : الحق في حرية التنقل والإقاهة وأثر حالة الطوارئ عليها.}

وهي حق الفرد في الانتقال من مكان إلى مكان والخروج من البلاد والعودة إليها

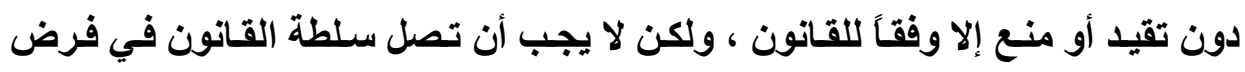
بعض القيود على هذه الحريـة إلى حد مصدادرتها أو إلغائهـا كلياً ـ ويعتبر حق التتقل

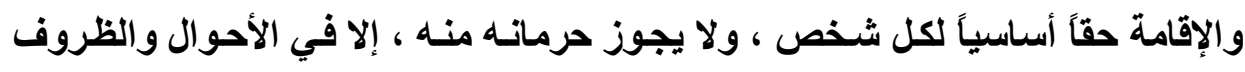

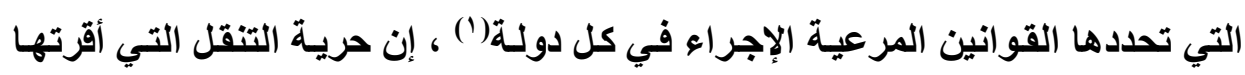

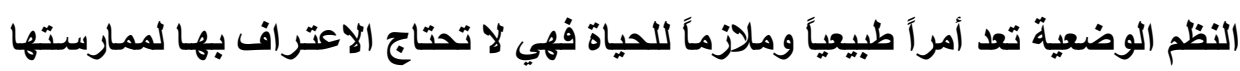
بقدر ما تحتاج إلى تنظيم لضمانة ممارسة هذا الحق على نحو يحقق مصلحة الإنسان

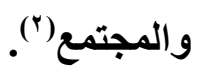

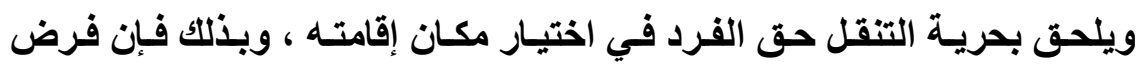
الإقامة الجبرية على الأشخاص الأين يثكلون خطراً على النظام العام سواء السياسيين

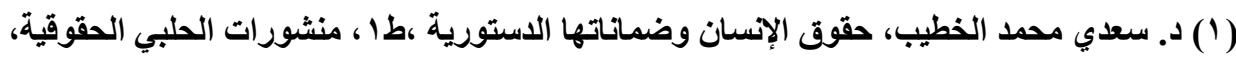

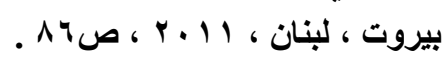

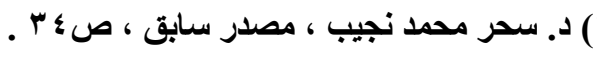


الذين قد يثيرون الشغب والاضطرابات ، أو المشبوهين وأرباب السوابق الذي يعكرون صفو الأمن العام ، بأن فرض الإقامة الجبريـة عليهم يجب أن يتم وفقاً لأحكام القانون

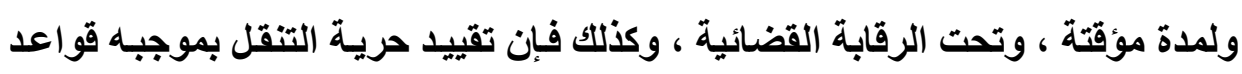

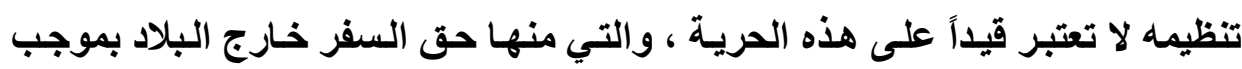
وثيقة جواز السفر ، وحرية التنقل واختيار مكان الإقامة وحظر الإبعاد وتتطبق أحكامها على المواطنين والأجانب المقيمين على إقليم الدولة وذلك على حد سواء باستثناء حظر الإله إبعاد اللاجئين السياسيين ، حيث أن الإبعاد حق مشروع للاول ، تقرره وفقاً للمصلحة

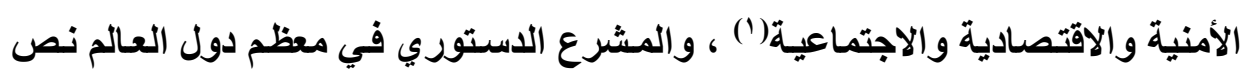
على حرية التنقل واختيار مكان الإقامة . أمسا بالنسبة للاستور العراقي لعام ه . . ب النافذ فقد نص على أن " للعراقي حرية التنقل والسفر والسكن داخل العراق وخارجه"(「).

أثر حالة الطوارئ على حق الإنسان في حرية التنقل والإقاهة وهنع الأبعاد . بما إن الإنسان كائن متحرك بطبيعته لا بـ له من التنقل والانطلاق من مكان إلى آخر بحسب ما يريل وذلتك لحمايـة صحته الجسمية والنفسية معاً ، ومن أقسى الأمور على نفس الإنسان أن تحدد إقامته في مكان معين لا يستطيع مغادرته ، أمسا إذا اقتضت

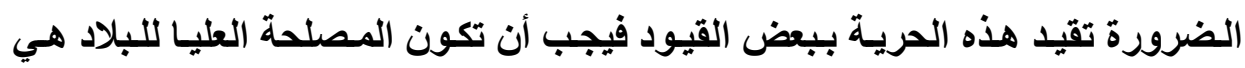
الباعث على ذلك ، وأن تكون هذه القيود في أضيق الحدود ولقترة مؤقتة ، وفي حدود

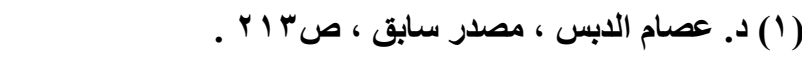

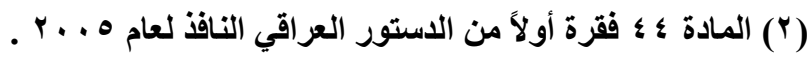


القـانون(') ففي الظروف الاستثنائية وعنــ إعلان حالـة الطوارئ ، يمكن للسلطات القائمسة على إجراء حالـة الطوارئ اتخـاذ جملـة من التـابير ، ومـن بين هذه التدابير فرض حظر التجوال والمرور ، وبهذا يمكنتا القول أنه في حالة إعلان حالة الطوارئ قد تتعرض حرية التتقل إلى التقيد بصورة كاملة بحيث يؤدي إلى إهدارها كلياً إذا فرضت السلطات القائمـة إجراء حالة الطوارئ وحظر التجوال والمرور ، على أن يكون هذا

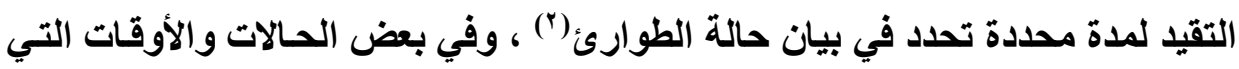
تعلن حالـة الطوارئ بسببها كـأن يكون إعلانهـا بسبب انتشار وبـاء فإنـه يكون مـن فئن الطوارئ اتخـاذ أمر بمنـع التقل والمرور بين المنطقة التي انتشر فيها الوبـاء وبين المناطق الأخرى ـ والمسلمون لجأوا إلى فرض القيود على حرية التنقل وذلك من أجل المحافظة على المصلحة العامة ، كما لو ترتب على السفر في هذه الحالة مؤقتاً بزمن ،

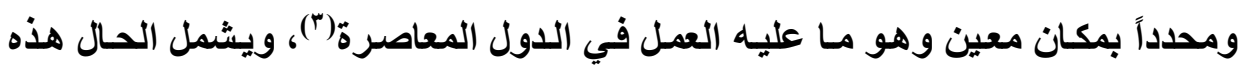
حصول الكوارث الطبيعية كالزلازل والبراكين والفيضانات وغيرهاء (؛ ) . ونصت قوانين الطوارئ العراقية على تقيد حرية التنقل بدءاً من مرسوم الإدارة

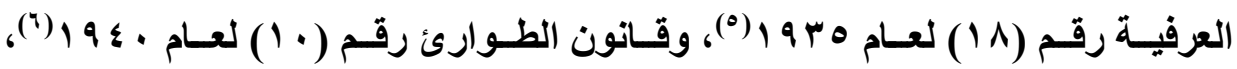

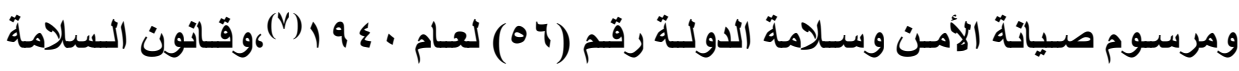

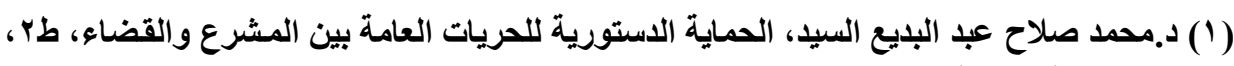

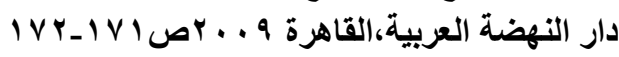

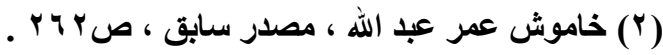

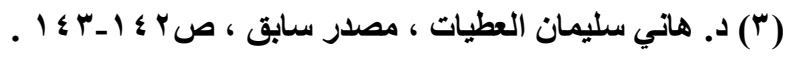

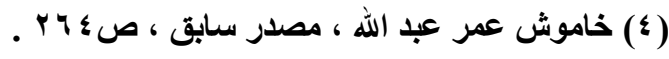

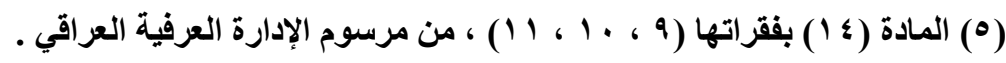

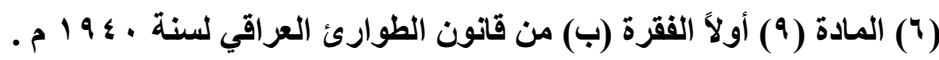

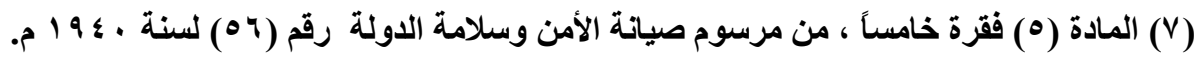




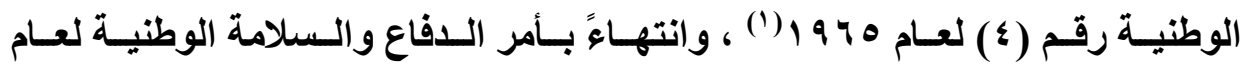

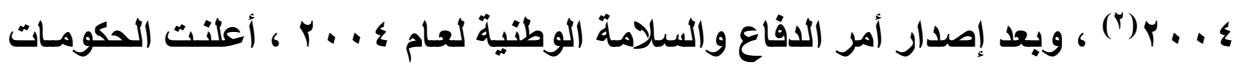
العراقية حالة الطوارئ لمرات عديدة في العراق باستثناء إقليم كردستان العراق ، بغية السيطرة على الانفلات الأمني الذي تشهره المنـاطق المعلنة فيها حالة الطوارئ وهو فرض حظر التجوال. فعلى سبيل المثـال قررت الحكومـة العراقية غلق حدود العراق وفرض حظر التجوال في البلاد لتعزيز الأمسن استعداداً للانتخابـات التي أجريـت في العراق ، ويمكنتا القول بأن إجراءات فرض حظر التجوال لها آثار سلبية مباشرة على إنى الحياة العامة للسكان وخصوصاً في العراق فهي تؤثر على نواحي الحياة كافة منها التجارة وأداء واستمرارية الموظفين في وظائفهم والأكثر تأثراً بها هو جانب التعليم وعدم قرة الطلبة للوصول إلى مدارسهم وكلياتهم ، وفي حالة الطوارئ فبإن ثمـة قيود عامة تفرض على حركة السكان بـكملهم حيث يكونون ملزمين بـاحترام التدابير التي

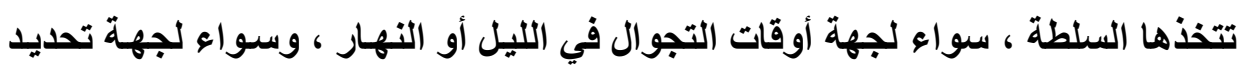
الفئـات المسموح لها بـالتجوال كالأطبـاء ، والصيادلة والممرضين في المستشفيات وأقسام الإسعاف ، وبعض القطاعات المهمة الأخرى(").

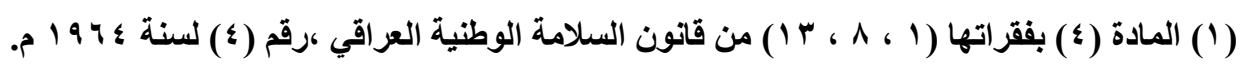

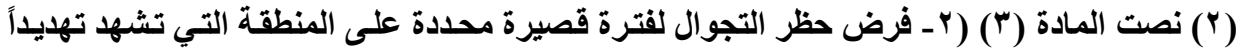

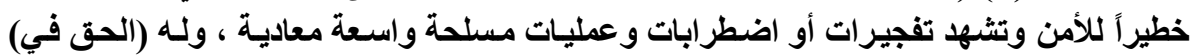

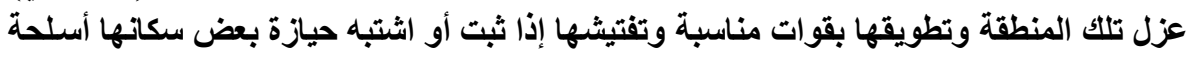

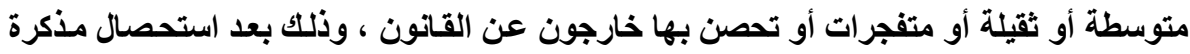

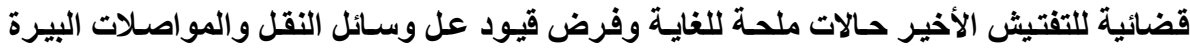

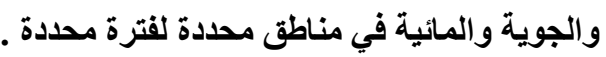

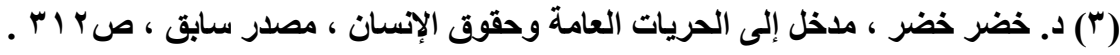




\section{رابعًا : حق التقاضي والماكمة العادلة وأثر حالة الطوارئ عليه.}

ويقصد بحق التقاضي أن لكل من وقع اعتداء على حقى من حقوقهـ أن يلجـأ. للقضاء لرد ذلك الاعتداء والانتصاف لنفسه ممن ظلمه وسلبه حقه ، وبمغنى آخر هو حق جميع البثر في الترافع إلى القضاء لعرض مظلمتهم والحصول على حقوقهم كاملة

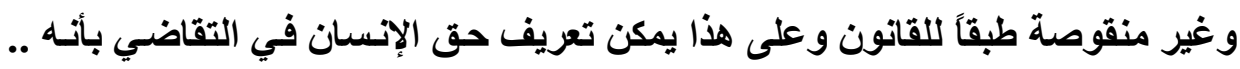

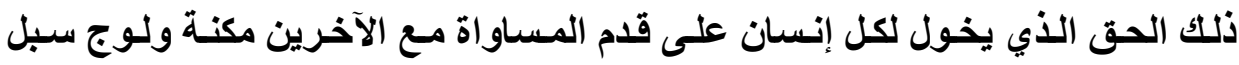
القضاء العام في الدولة المكفول أمامه جميع ضمانات المتقاضين بكافة أنواع ودرجاتها للانتصاف لنفسه أو لحقوقه المشروعة" (وبين التعريف السابق أن لحق الإنسان في

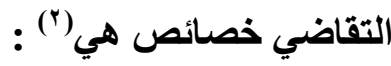
1- - أنه حق أصيل من حقوق الإنسان . r- أنه حق ينتفع به كل إنسان على قدم المساواة التامة مع الآخرين . r- يرتبط هذا الحق بالسلطة القضائية ارتباطساً وثيقًا باعتباره السلطة المختصة

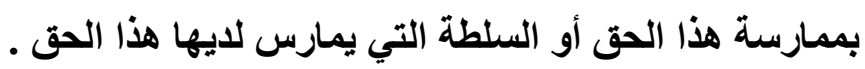
؟ - يتميز هذا الحق باتساع نطاقه فهو غير مقصور على منازعات معينة وإنما يشمل

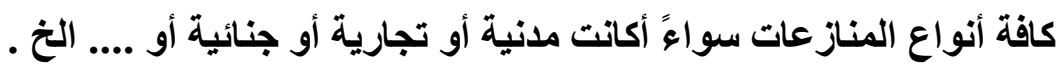

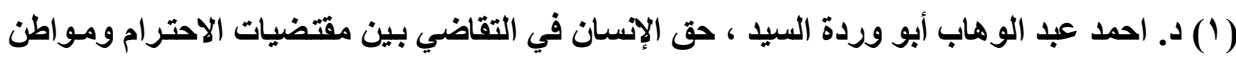

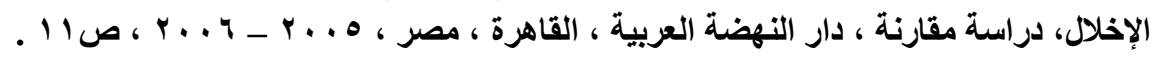

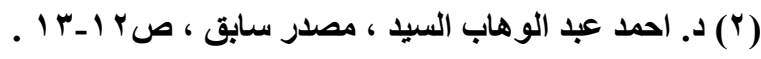




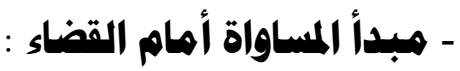

يقضي مضمون مبدأ المساواة أمسام القضاء أن يكون القضاء الذي يتقاضسى

أمامـه الجميع واحداً ولا تختلف المحاكم بـاختلاف الأشخاص الذين يتقاضون أمامها، وأن تكون إجراءات التقاضي التي يتبعها المتقاضون واحدة فضلاً عن وحدة القانون المطبق على الجميع ومعاملة جميع المتقاضين معاملة متساوية دون تمييز بينهم (')، والمسساواة أمسام القضاء مسن المبـادئ الأسـاسية التـي يقوم عليهـا نظسام القضاء في الإسلام، لا يوجد نظام قضائي في العالم المعاصر اهتم بمبدأ المساواة بمثنل مـا اهتم بـه النظام القضائي الإسلامي ، فقد قرر هذا النظام مبدأ المساواة بين الناس أمسام القضاء ـ القدي بل جعل المساواة بين الخصوم بمثابة الأسـاس الأي يرتبط بـه - وجوداً وعدماً ـ كافة

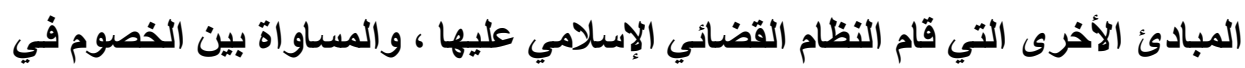
مجلس القضاء في النظام الإسلامي يعد لازمة ومطابقة من ناحية أخرى ، فهي لازمـة بنصوص الكتاب (القرآن أو السنة وأعمال السلطة ، وهي مطلقة بمعنى أنها شاملة لكل النـواحي بـاللفظ أو الخلط في المجلس ـ حيث لا يعرف النظـام الإسـلامي تفرقة بـين

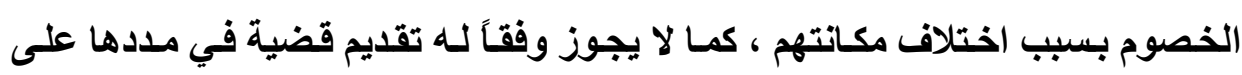
قضية أخرى كما أن القاضي لا يقضي دون سماع طرفي الدعوى(؟). وتتساول قـانون التظظيم القضائي العراقي رقم ( • 19 ) لسنة 9 و حيث حدد تقسيمات المحاكم ولا يجوز إيجاد محاكم أخرى خـارج هذا التقسيم وبذلك فـان السلطة التنفيذية انتهكت وتجاوزت على القانون من خلال إقدامها على إنشاء محاكم خاصـة 


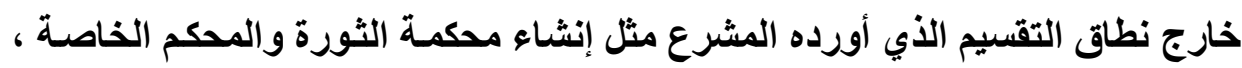

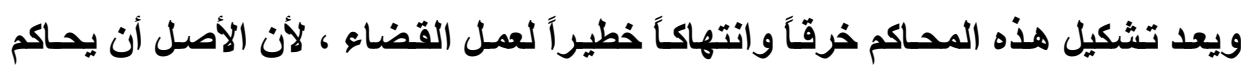

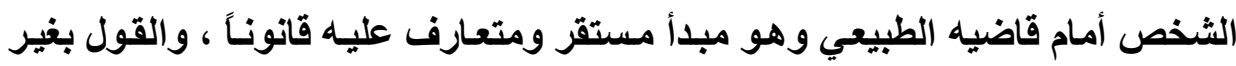

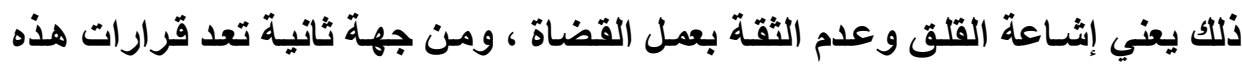

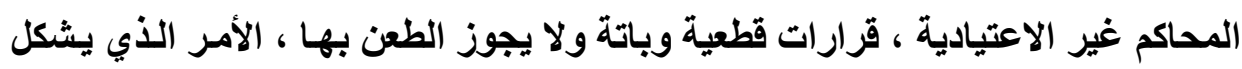

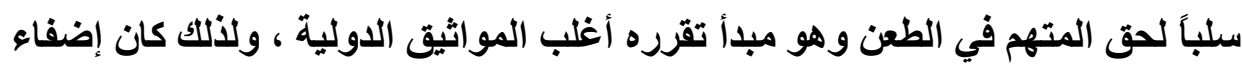
الثرعية على وجودها يقتضي على الأقل إخضاع قراراتها للطعن أمسام محكمة التمييز حماية لحقوق الإنسان وحرياتهم (')

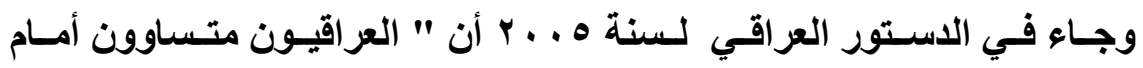

القانون دون تمييز بين الجنس أو العرق أو القوميـة أو الأصل أو اللون أو الدين أو الو

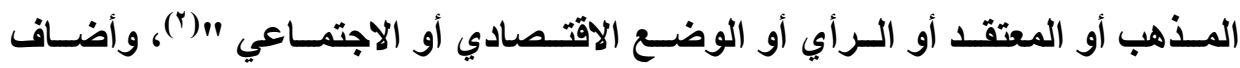

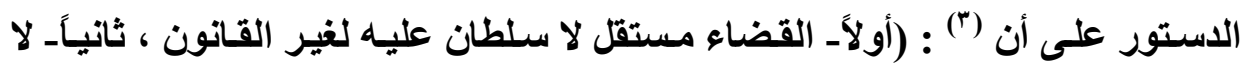
جريمة ولا عقوبة إلا بنص ، ولا عقوبة إلا على الفعل الذي يعده القانون جريمة وقت التاني

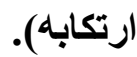

\section{أثر حالة الطوارئ على حق الإنسان في التقاضي.}

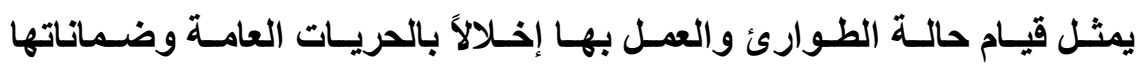

الاستورية ، لاسيما في ظل قوانين الطوارئ و هذا الإخلال له عدة وجوه أهمها(") :

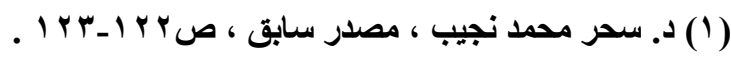

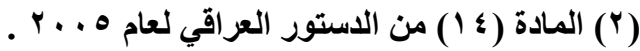

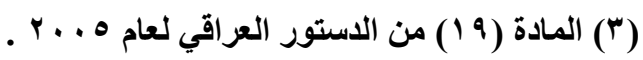

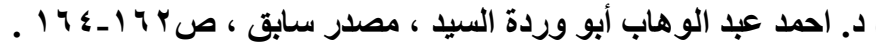




\section{أولاً إطلاق يد سلطة الأحكام العرفية}

مـن أهـ الآثـار المترتبـة على إعلان حالـة الطوارئ والعمل بقوانينهـا إطلاق يد سلطات الأحكام العرفية في التصرف واتخاذ التابير اللازمة لمواجهة حالة الطوارئ دون أيـة قيود أوتحمل لتبعة المسؤولية بالنسبة لهذه الأوامر وتلكك التدابير التي قد تـضر بمـصالح العديـد مسن الأفـراد لـصدورها فـي ظـروف اسـتثنائية غيـر عاديـة ، تتوقف الحريـات العامـة والضمانات الاستورية لها ، وممـا لا شـك فيـه أن نظامـاً كهذا يهدد الحقوق والحريات العامة الممنوحة للأفراد وأهمها حقهم في اللجوء إلى القضاء وذلك عن طريق القيود التي تضعها سلطة الأحكام العرفية لممارسـة الحقوق والحريـات العامـة الممنوحـة للمـواطن بمقتضى الاسـتور بحجـة المحافظـة على الأمسن والنظــام

ثانياًا إضفاء صفة المشروعية على تصرفات المكوهة رغم عدم هـشروعيتها في

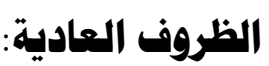

إن من أهم وأخطر النتائج المترتبة على العمل بقوانين الطوارئ أن القضاء قد وسع من نطاق المشروعية لصالح الإدارة على حسب حقوق الأفراد وحريـاتهم العامـة فالقاعدة في مثل هذه الظروف هي أن القضاء الإداري يعامل قرارات سلطة الطوارئ

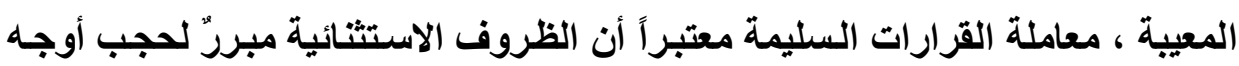
عدم المشروعية التي شـابتها ، سواء بسلطة الإلغاء أو على بساط التعويض ، وهذه السياسة القضائية هـي في حقيقتها عمليـة ترجيح لاعتبـارات المحافظة على كيـان 
الدولة'(1) ، حيث يقوم القاضي الإداري عن طريق دعوى الإلغاء بمراقبة مشروعية

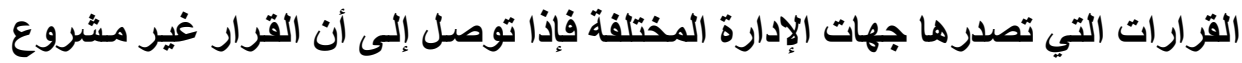

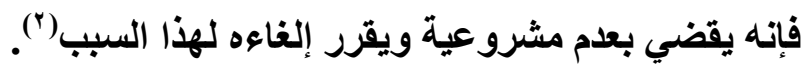

\section{ثالثًا إسناد النظـر والطعن على قـرارات سـلطة الأحكام العرفيسة إلى جهـة}

\section{قضائية استثنائية}

وأهم أثر يترتب على قيام أو إعلان حالة الطوارئ هو إنثاؤها محاكم استثنائية

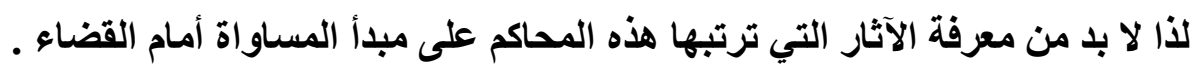
أما بالنسبة للاساتير العراقية بعد الاحتلال ففي ظل قانون إدارة الدولية للمرحلة

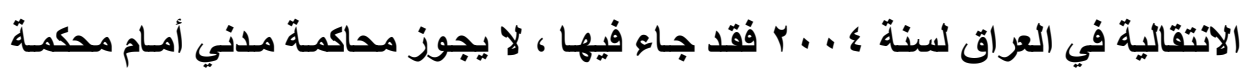

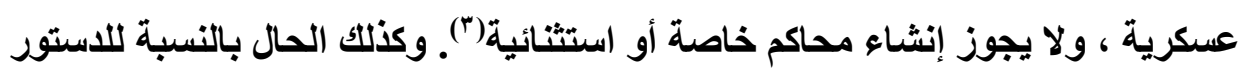
النافذ لعام ه . . Y (4) حيث جاء فيه " يحظر إنشاء محسكم خاصة أو استثنائية " وبمـا

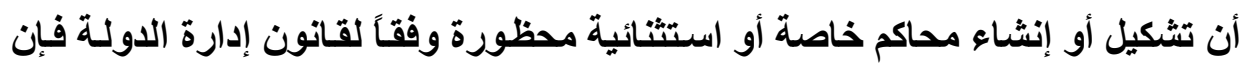

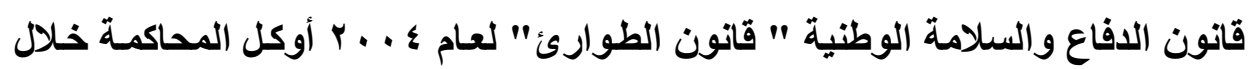

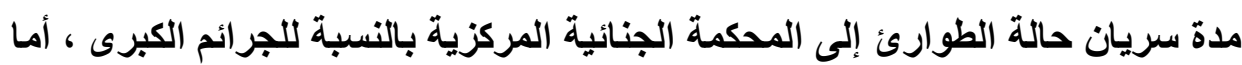

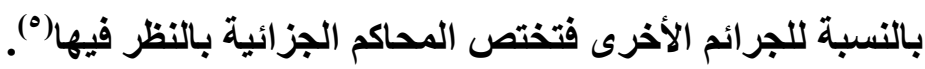

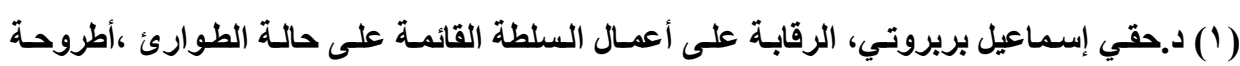

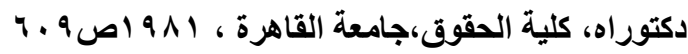

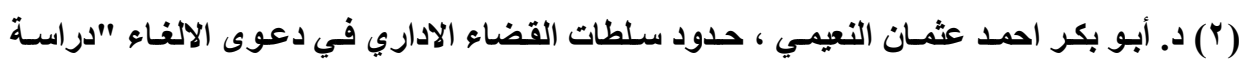

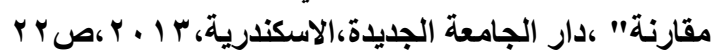

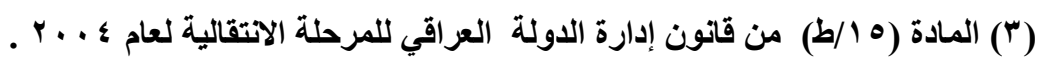

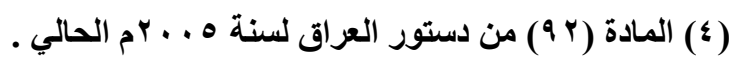

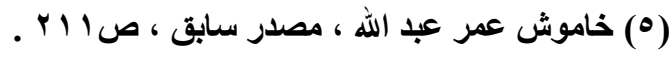


بالرغم مـا نص عليه القـانون والاستور غير أنـه تم تشكيل محساكم خاصـة في العراق والتـي تعتبر مخالفة دستورية ومخالفـة للمعـيير الدوليـة وأبرز تلك المحسكم المحكمة الخاصة بمحاكمـة رموز النظام السابق حيث شكلت ابتداءً المحكمة الجنائية الخاصة بموجب القانون رقم ا لسنة ب . . r والمشكل من قبل سلطات الاحتلال وحل محله لاحقاً قانون المحكمة الجنائية العراقية العليا وهي محكمة إستثنائية رقم • 1 لسنة ه . . r وكان أبرز القضايا محل نظر أمام المحكمة هو محاكمة الرئيس العراقي الراحل

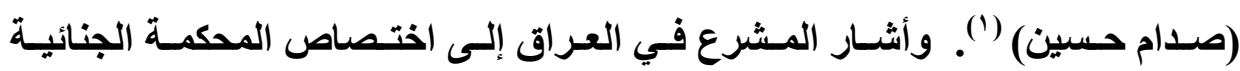

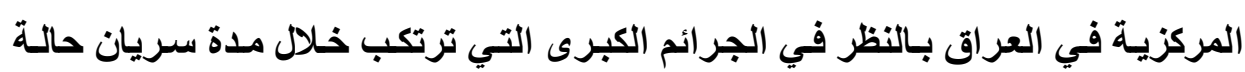

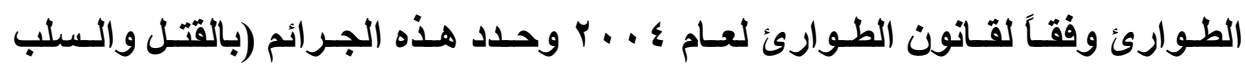
والاغتصاب والاختطاف والتخريب والتفجير أو إحراق أو إتلاف الأموال العام والخاصـة وحيازة الأسلحة الحربية وعتادها أو صنعها أو نقلها أو تهريبها أو المتاجرة بها) ، أمسا

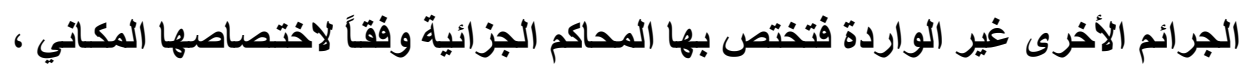
وبخصوص التحقيق في الجرائم التي تحدث أثناء حالة الطوارئ فإن قضاة التحقيق كلاً حسب منطقتهـه واختـصاصه المكـاني والنـوعي يتولــون التحقيـق فـوراً فـي الجـرائم المذكورة(؟) ، كما أجيز لرئيس مجلس القضاء أو رئيس المحكمة الاتحادية أن ينتدب بعض القضاة والمحققين للتحقيق بلاًا من قضاة التحقيق في جريمـة أو نوع معين من الجرائم إذا كان ذلك ضرورياً.

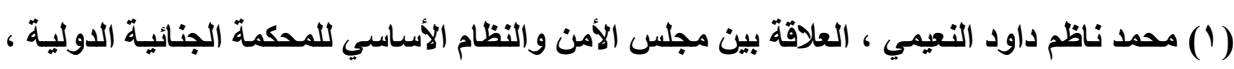

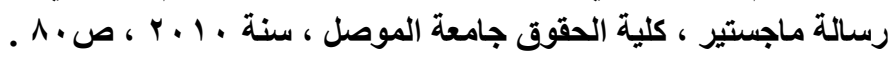

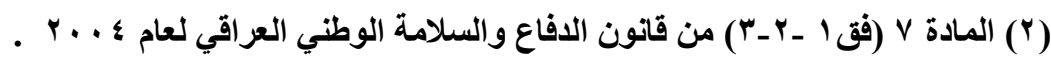




\section{- أثر الماكم الاستثنائية في مبدأ المساواة أهام القضاء :}

إن المحاكم الاستثنائية التي تنشأ بموجب ظروف استثنائية تختلف من حيث تكوينهـا وتششكيلها وإجراعاتهـا عـن المحساكم العاديـة ، فقـانون الطـوارئ هـو ضـمن اختصاصات هذه المحاكم وغالباً ما تكون متعلقة بالجرائم ذات الطابع الأمني ، ويتجلى ظرف مبدأ المسـاواة أمسام القضاء عنــ إنشاء المحساكم الاسـتثنائية في ظل قوانين

الطوارئ في عدة أمور يمكن استخلاصها في أربع نقاط. (')

ا - عدم وجود محكمة عليا للتدقيق في القرارات التي تصدرها المحاكم الاستثنائية ، حيـث أن قـوانين الطـوارئ جعلـت قـرارات المحساكم الاسـتثنائية قطعيـة بمجـرد التصديق عليها من قبل الجهات المختصة ومن ثم لا يتمتع المتهم بحق الطعن في

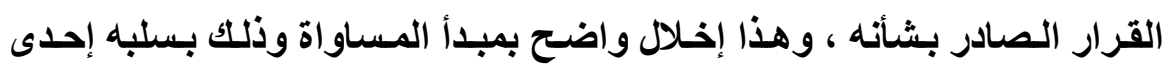
الضمانات المهمة لإجراء محكمة عادلة ـ وهو يتــاقض مـع العهد الدولي للحقوق (ن) المدنية والسياسية. r- إن مظهر الإخلال بمبدأ المساواة في تشكيل المحاكم الاستثنائية في ظل قوانين الطوارئ يمثل في أن تلك القـوانين تجيز اشـتراك الـضباط في تشكيل محسكم استثنائية على أن يكون التشكيل كاملاً من الضباط بالنسبة لقضايا معينة وهؤلاء الضباط لا تتوافر فيهم الخبرة الكافية ولا الدراسة القانونية لممارسة القضاء وهو ما يمثل مخالفـة صريحة لمبدأ المساواة إذ تؤدي إلى حرمسان المتهم من المثول 
أمام قاضيه الطبيعي المتخصص لمجرد إعلان حالة الطوارئ ويناءُ على مشيئة

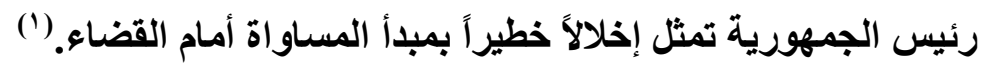
؛ - وكما ذكرنا فإن قوانين الطوارئ تحيل بعض الجرائم التي يعاقب عليها القانون

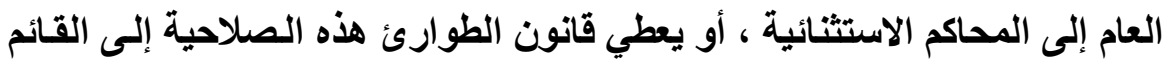

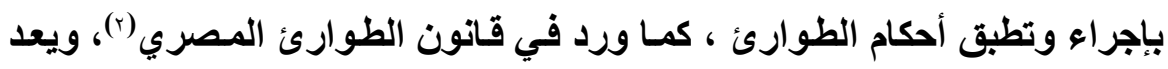
هذا تفويضاً في تحديد اختصاص هذه الححاكم إلى الحد الذي يعطيه الحقى في إحالة الذيأ

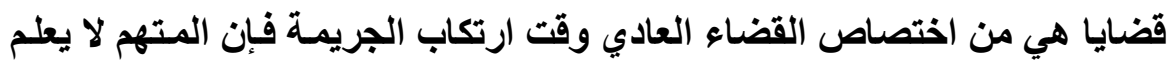

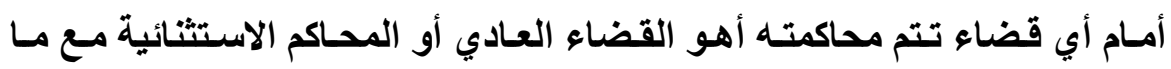
ينطوي عليه ذلك من إخلال بالمساواة .

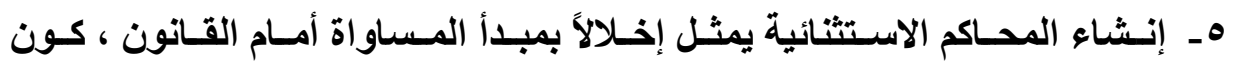
الإجراءات المتبعة في المحسكم الاستثنائية المشكلة في ظل قوانئ النئ الطوارئ تختلف عما هي في القضاء العادي ولا تتو افر فيه الضمانات .

\section{خاهساً : حق الثصوصية وأثر حالة الطوارئ عليها .}

وهو حق الإسسان في أن تحترم الحياة الخاصة بـه ، وأن تحفظ أسراره التي يجب ألا يطلع عليها الآخرون بغير إذنه(")، وعرف حق الخصوصية أيضاً " بأنه الحق الحقان في الخلوة ، بمعنى آخر رغبة الشخص في أن يكون وحيداً ومتخفياً ومتحفظًا ، وهذا لأنها

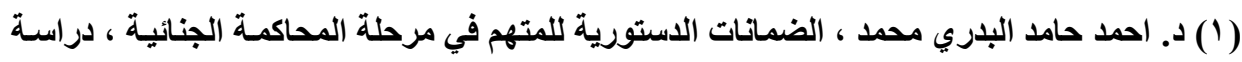

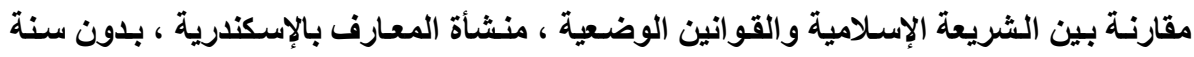

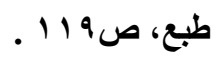

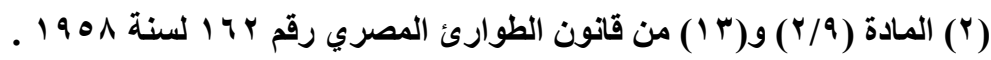

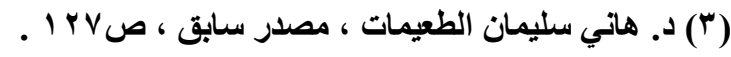


جميعه يــلـل تحس فكرة أن يترك الشخص وشـأنه ، ومسن دون تــخل وتطفل مـن

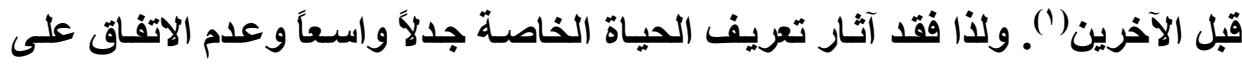

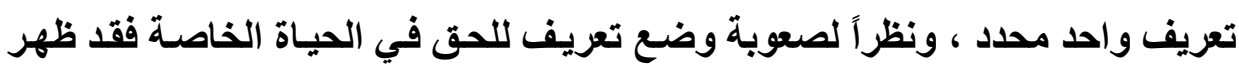

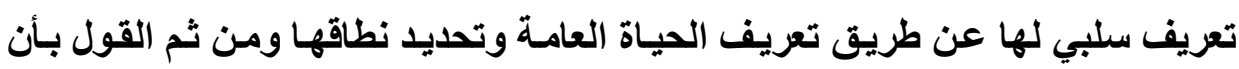

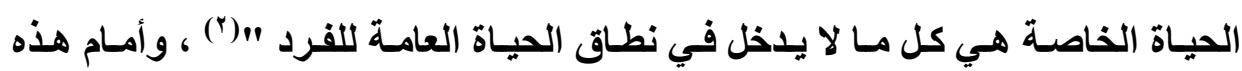

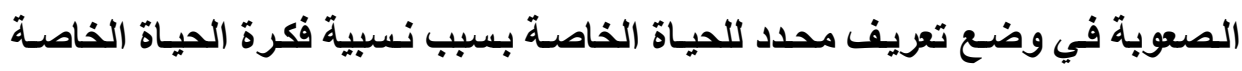

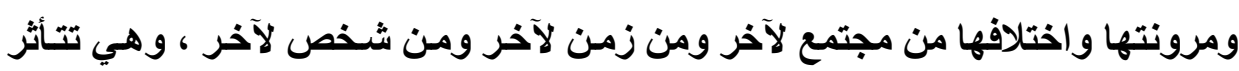

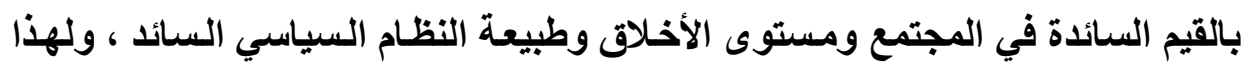

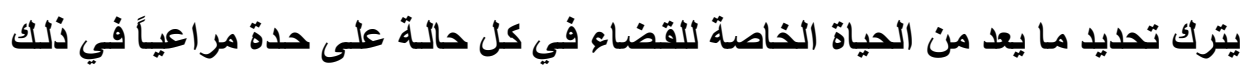

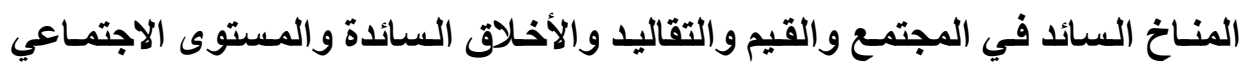

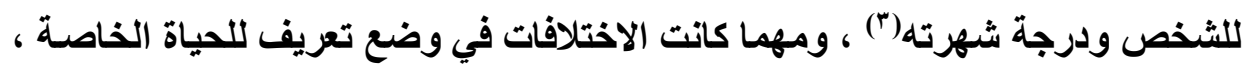

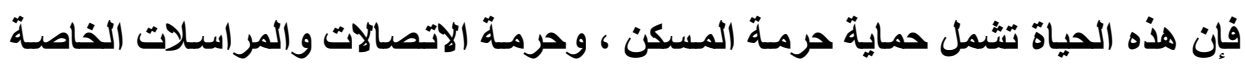

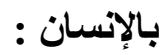

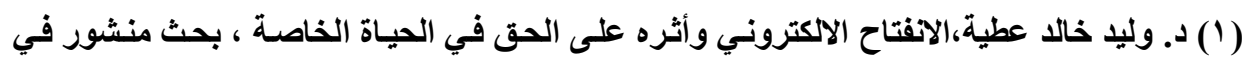

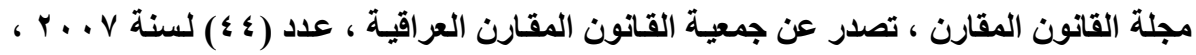
ص صن 10. (ץ) د.مصطفى احمد عبد الجواد حجـازي، المسؤولية المدنيـة للصحفي عن انتهاك حرمـة الحيساة

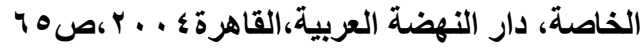

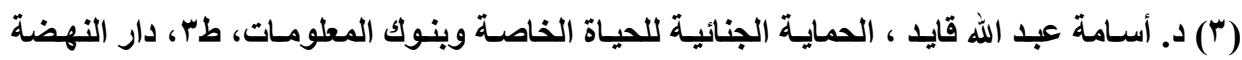

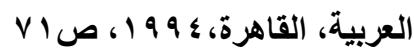




\section{صور حق الخصوصية وأثر حالة الطوارئ عليها:}

أولاً : الحق في حماية حرهة المسكن :

المسكن يصدق على كل ما يأوي إليه الإنسان ويقم فيه ، سواء عن طريق الملك

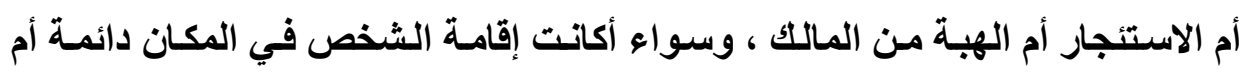

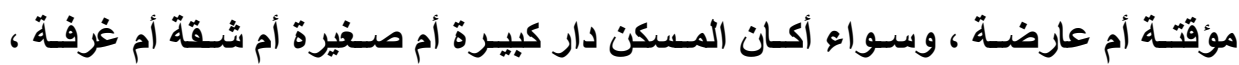

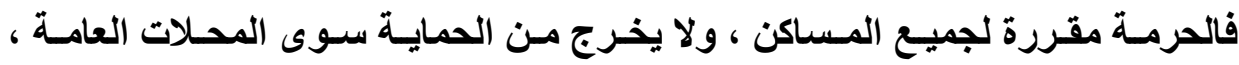

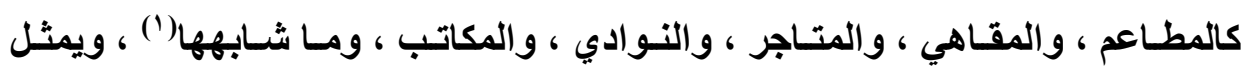

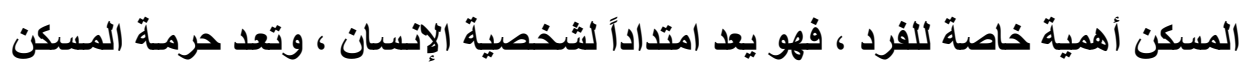
امتداداً لحريـة الإنسـان الشخصية وحقه في أن يكون لمسكنه حرمـة وقدسية فمسكن الفرد هو مكان حياته الخاصـة ، ولا بـد أن نشير أن مسألة الاستئذان لـ تترك بشكل عشوائي دون وضع ضوابطوحدود ، فقد عرفت المجتمعات ، طريقة الاستئذان التي هي تعبير يوصي بالتزام المواطن بالآداب العامة المتعارف عليها في المجتمعات، والتي هي إجراء وقائي للحق من التجـاوزات(؟) ، وقد جـاء في الدستور العراقي النافذ لعام

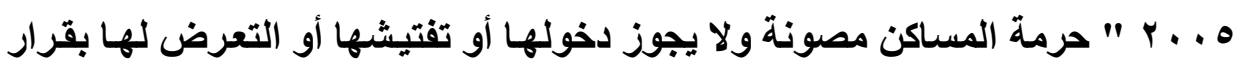

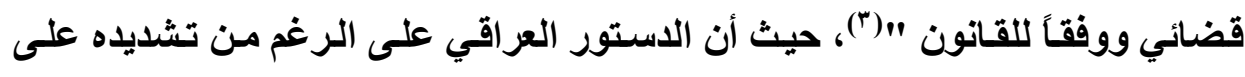
الثروط الواجب توافرها لإجراء التفتيش حيث أنه لم يكتف فقط بـالنص بقرار قضائي بل أضاف إليهه وفقاً للقانون ، غير أن الواقع العملي يشير إلى عكس ذلك فالشواهد

(1) د. ثروت بدوي ، النظم السياسية ـ النظرية العامة للنظم السياسية ، دار النهضة العربية ، الجزء

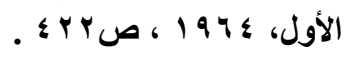

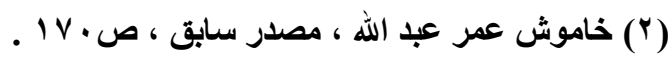

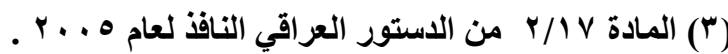


الواقعية واليومية لحياة العراقيين وانتهاك حرمـات منـازلهم وإجراء التفتيش دون إذن

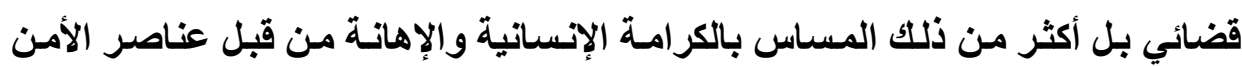

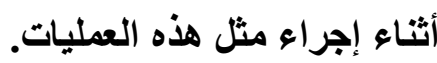

\section{ـ الحماية القانونية لحق الإنسان في حرهة المسكن (التفتيش) :}

يعد التفتيش من الإجراءات الماسـة بالحريـة الثخصية ولكن المشرع أجساز

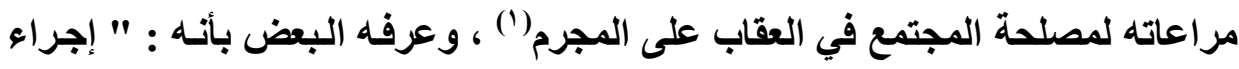
من الإجراءات التي تهاف إلى ضبط أدلة الجريمة موضوع التحقيق التهيق وكل مـا يفيد في

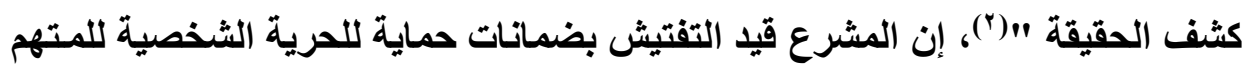

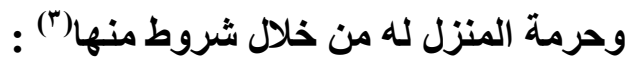
ا- صدور قرار التفتيش هن حاكم التحقيق : • وقوع جريمة قبل إصدار القرار بإجراء التفتيش ـ • حضور المتهم إجراءات التفتيش . • الوقت الذي يجري فيه التفتيش .

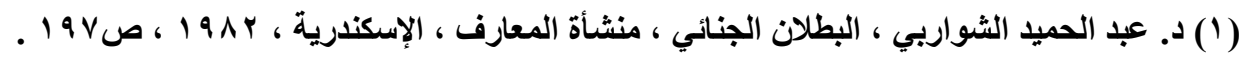

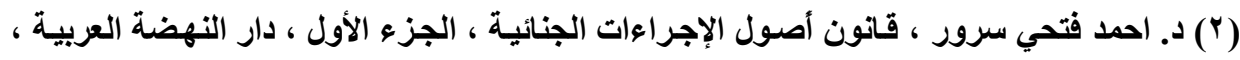

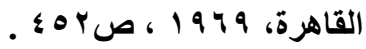

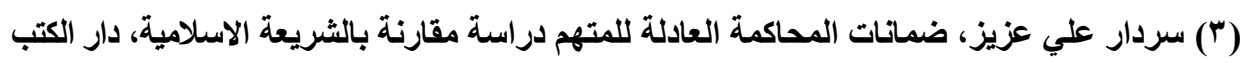

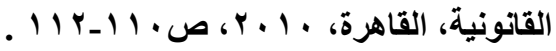




\section{r- أثر حالة الطوارئ على حق الإنسان في حرهة المسكن}

لابد من تسليط الضوء على التفتيش الإداري وحالات الضرورة حيث أنه ليس

من الشائع بحث حسات التقتيش الإداري وحالات التقتيش استتاداً للضرورة معاً ، باعتبار أن حالات الضرورة لا تحتاج لأذن من أي نوع بينما في حالات التفتيش الإداري

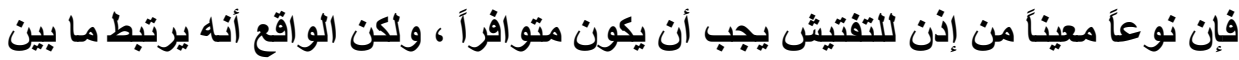

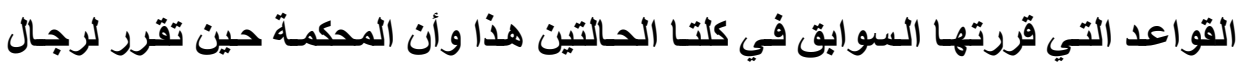

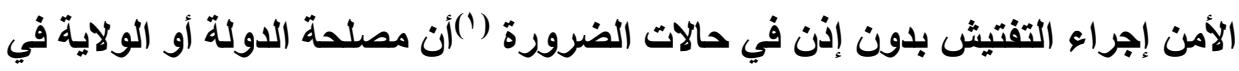
إجراء التفتيش ترجح حق المواطنين الخصوصية .

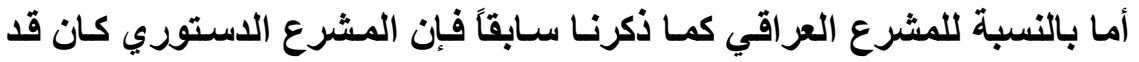

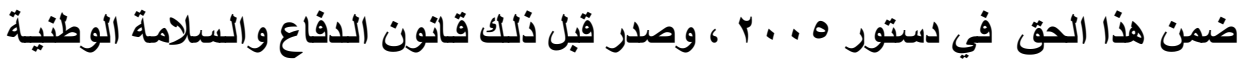

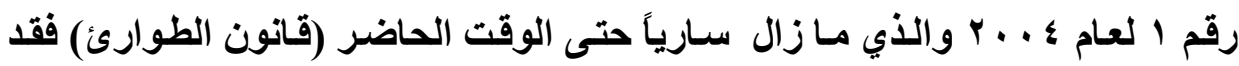

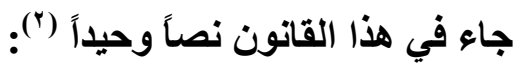

- يخول رئيس الوزراء في حالة الطوارئ وفي حدود منطقة إعلانها بالسلطات

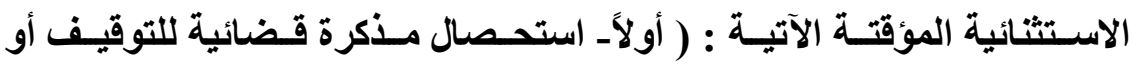

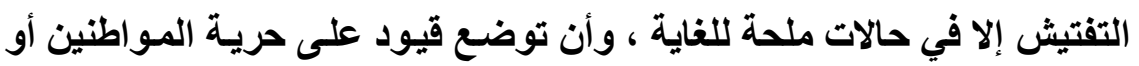

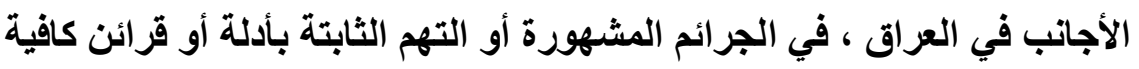

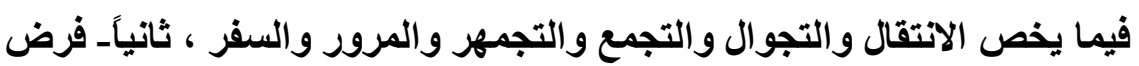

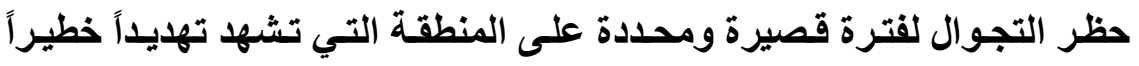

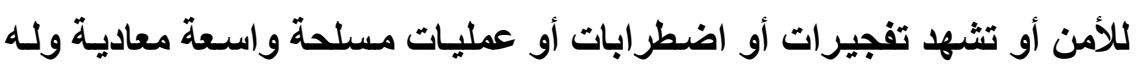

(1) د. حسن شلبي يوسف، الضماتات الدستورية للحرية الثخصية في النظامين الانكليزي و الامريكي

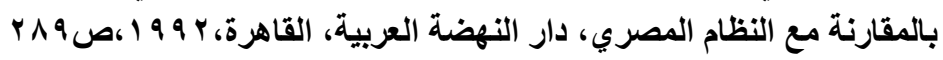

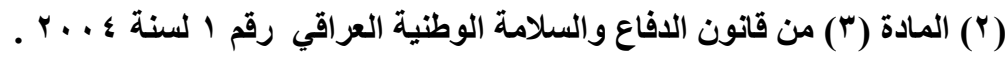


(الحق في) عزل تلك المنطقة وتطويقها بقوات مناسبة وتفتيشها إذا ثبت أو أو أونات

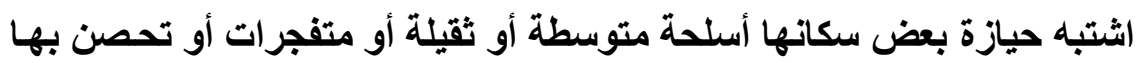

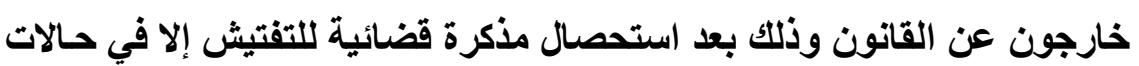

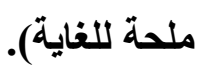

واستناداً للنص السالف فِإن هناك شروطاً للإذن بالتفتيش ووجود ثغرات عديدة

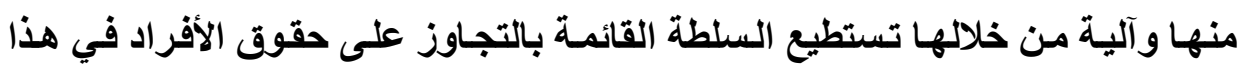

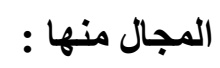

(1) يثترط الحصول على إذن قضائي ويضيف الفقرة الأولى عبارة " إلا في حالات

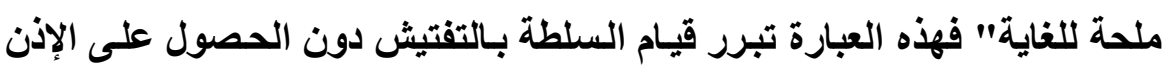

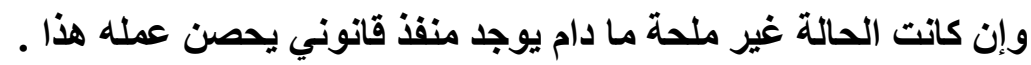

(Y) وجود أدلة وقر ائن ثابتة لوقوع جر ائم وغالباً مـا نشهـ في الو اقع العملي ظروفاً وأوضاعاً بالرغم من عدم وجود جرائم أو دلائل وبراهين تجري السلطة عمليات

$$
\text { التفتيش. }
$$

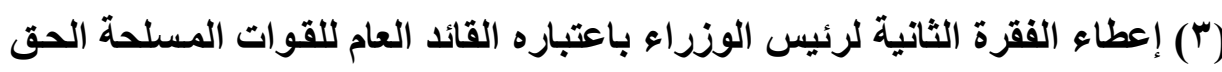

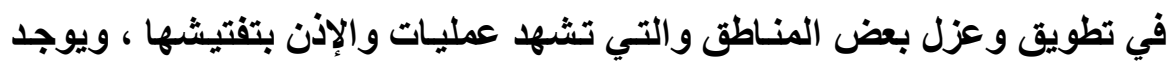

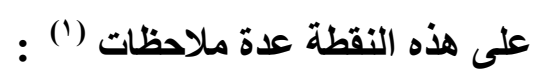

أـ أن الحق في التطويق والإذن بالتفتيش من صلاحيات رئيس الوزراء والواقع

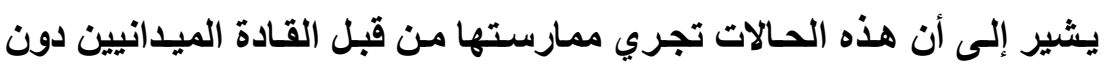

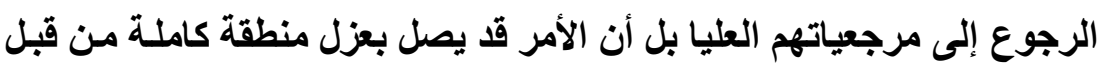

ضابط تلك المنطقة وحسب رغبته وتقديره دون وجود حسيب ورقيب عليه .

(1) د. حسن شلبي يوسف ، مصدر سابق ، صو ץ . . 
بـ إن هذا النص يتناقض مع شرط موضوعي مسلم به في مجال عمليات تفتيش

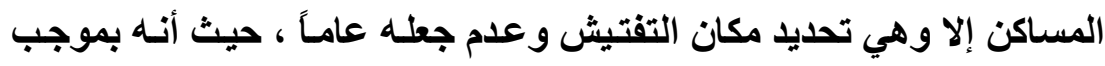
هذه المـادة يجوز إجراء تفتيش وتطويق منــاطق كاملـة دون تحديد للمكـان المحدد وفيه تجاوز على حرمة مساكن المواطنين ، وهذه النقطة هي جوهر معاناة الثعب العراقي في الوقت الحاضر من ممارسات تقوم بها نظام الحكم

$$
\text { القائم حالياً . }
$$

\section{حرهة المراسلات والاتصالات الخاصة بالإنسان :}

من الأمسور الخاصـة بالإســان : المراسـلات البريديـة وكافة الاتصالات البرقية

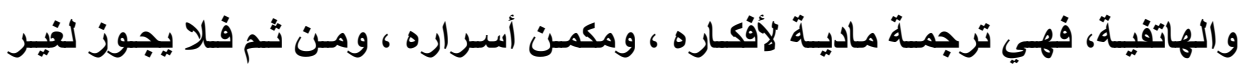

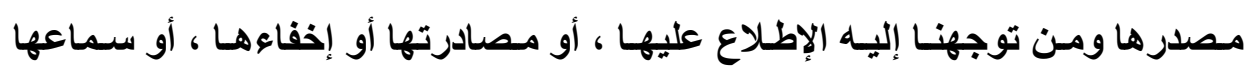
بطريق التصت بأي وسيلة من الوسـائل ، وسـواء كـان ذلكك بحاسـة السمع أو تسجيلاً

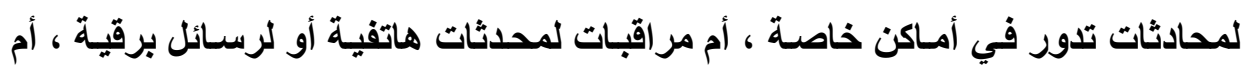
تصوير الجميع الأجهزة التقتية الحديثة(')، وأنها نتيجة التقدم العلمـي والتقـي ووجود بنك للمعلومات أصبح من السهل التعرض لخصوصيات الأفراد دون علمهم(").

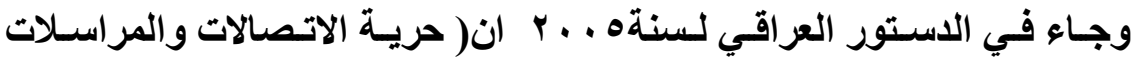

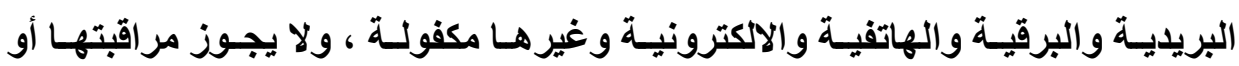

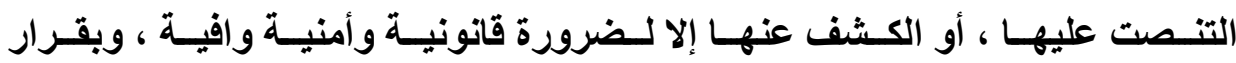

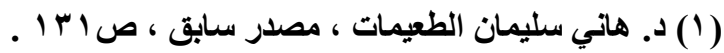

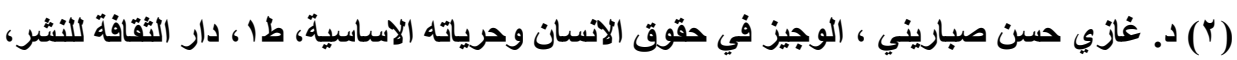


قضائي)." (') ، والملاحظ على نص هذه المـادة بـالرغم مـا تضمنته من ضمانات عدم المر اقبة والكثف والذي بـأ بـه النص غير أنـه قد جاء في نهايـة النص عبارة إثارة الكثير من الشك وهي عبـارة (الضرورة القانونية) وأضساف بقرار قضائي ، ولحرمـة المراسلات والاتصالات أهمية كبيرة في الحياة المعاصرة نتيجة التطورات الكبرى في

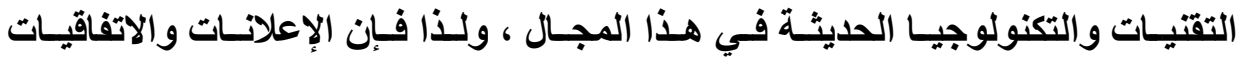
والمعاهدات الدولية قد أولت لهذا الحق من حقوق الإنسان أهمية من خلال تضمين نصوص خاصة تتعلق بها .

\section{أثر حالة الطوارئ على حق الإنسان في سرية هراسلاته واتصالاته :}

إذا كاتت سرية المراسلات ثقرر عدم جواز انتهاك المراسلات البريلية والبرقية والهاتفية فإن هذه السرية لم تكن مطلقة في بعض الاساتير التي نصت صراحة على أنه يمكن تقيلها في الحالات التي بينها القاتون("). والحالات التي يمكن أن تتعرض هذه السرية فيها للاتتهاك إما أن تكون في ظروف عادية أو ظروف استثنائية تمر بها الدولة ـ ففي الظروف العادية تجيز معظم الدول مراقبة المراسلات البريدية والبرقية والهاتفية للكثف عن جريمة يخطط لها منفذوها وذلك بالحصول على إذن قضائي مسبق بذلك ،

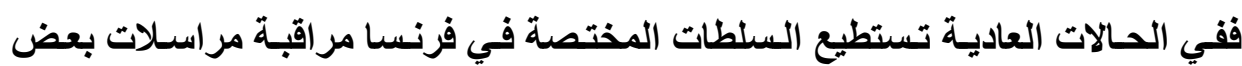
الأشخاص الذين تعتبر تحركاتهم ، أو اتصالاتهم ، أو علاقاتهم داخلة في نطاق الأمن والسلامة العامة(ب).

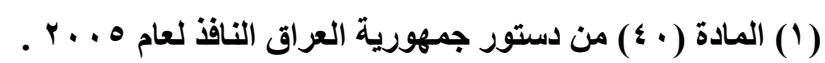

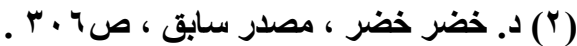

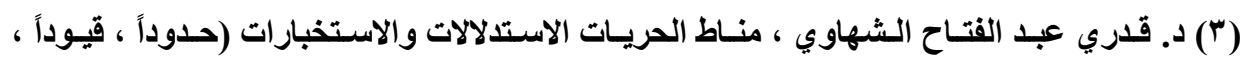

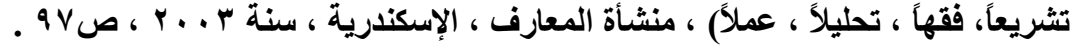




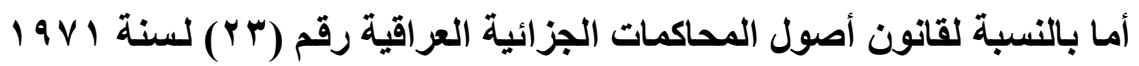

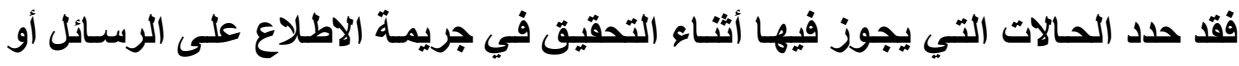

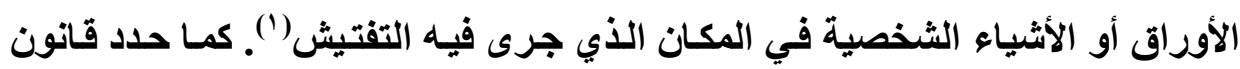

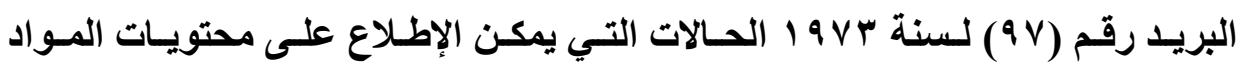

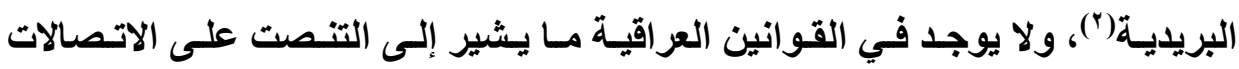

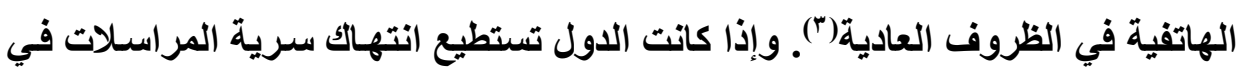
الظروف العادية ولكن في نطاق ضيق جداً وفقاً للإجراءات التي تتطلبها قو انين الأصول

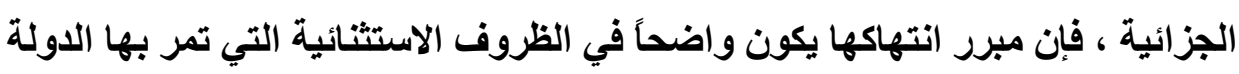

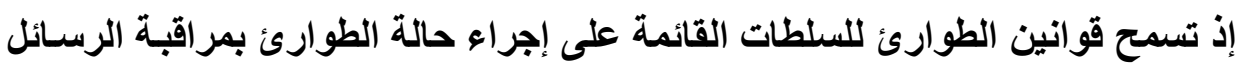

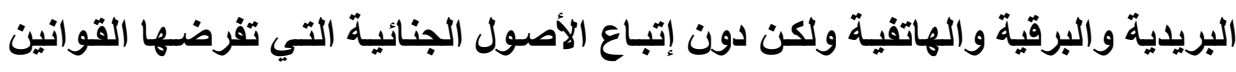

$$
\text { كما هي الحال في الظروف العادية . }
$$

وجاء في أمر الدفاع عن السلامة الوطنية العراقي رقم (1) لسنة ؛ ـ . ب مختلفاً

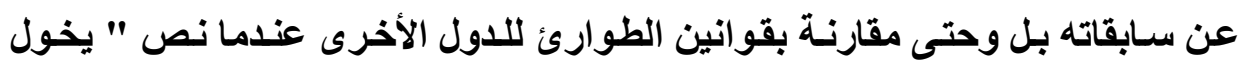

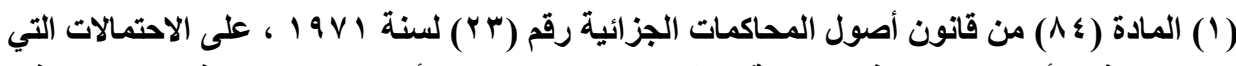
يجوز فيها أثناء التحقيق في جريمة الاطلاع على الرسائل والأوراق الموجودة في المكان الكان الذي الذي

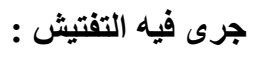
أـ إذا كان بين الأشياء في المكان الذي جرى تفتيشه رسائل أو أوراق أو أشياء شخصية أخرى

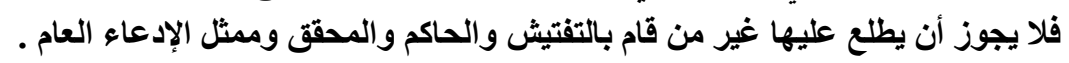

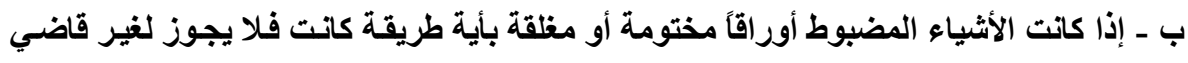

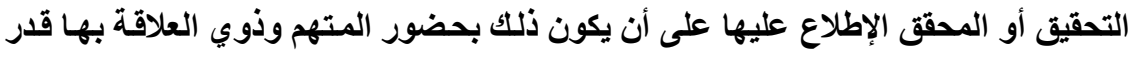

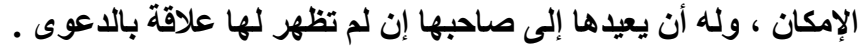

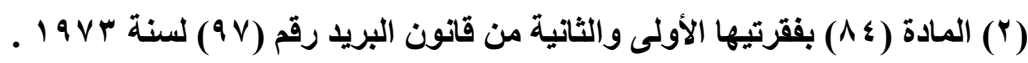

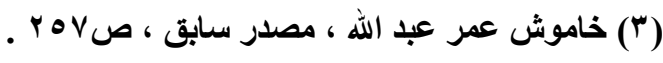


رئيس الوزراء في حالية الطوارئ وفي حدود منطقة إعلانها بالسلطات الاستثنائية المؤقتـة الآتية : اتخـاذ إجراءات احترازية على الطرود و الرسـائل والبرقيات ووسيائل وأجهزة الاتصال السلكية واللاسلكية كافة إذا ثبت استخذامها في الجرائم المشار إليها أعلاه ، ويمكن فرض المراقبة على هذه الوسائل والأجهزة وتفتيشها وضبطها إذا كـان ذللك يفضي إلى كثف الجرائم المذكورة أو يمنع وقوعها وذلك بعد استحصال مذكرة من الجهات القضائية المعنية لفترة زمنية محدودة'(')

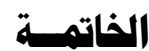

بعد الانتهاء من دراسـة موضوع حالـة الطوارئ وأثرهـا على حقوق الإسسان

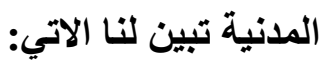
أولاً : النتائج :

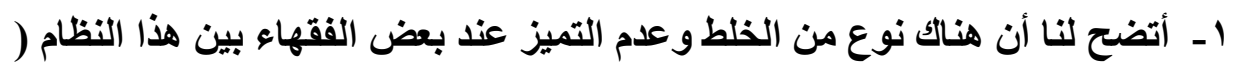

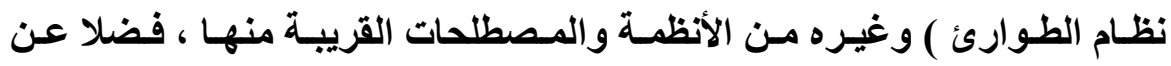

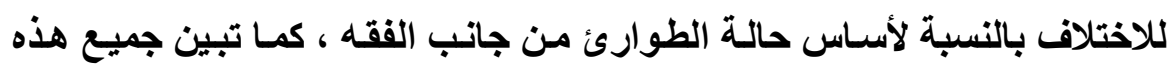

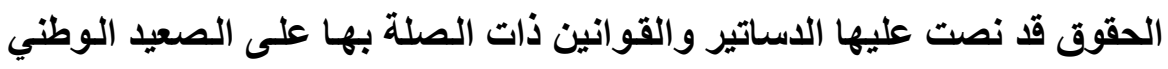

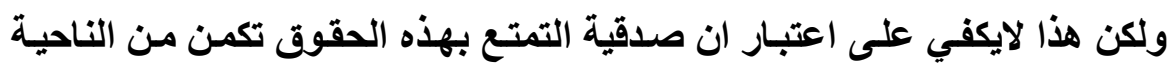

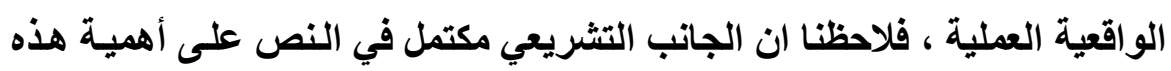

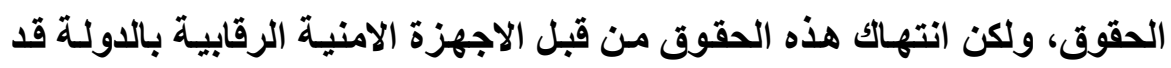
افرغت هذه الحقوق المنصوص عليها من محتواها جملة وتفصيلا . 
r- تبين لنا من خلال البحث ان قانون السلامة الوطنية العراقي الذي يعالج حالة

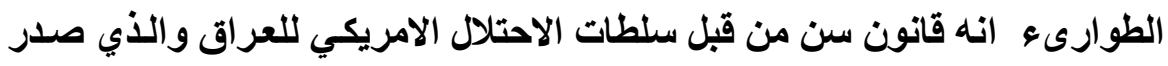

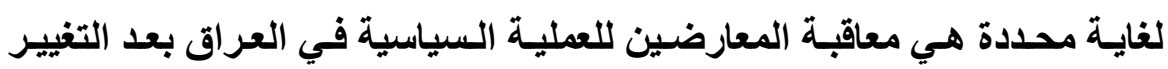

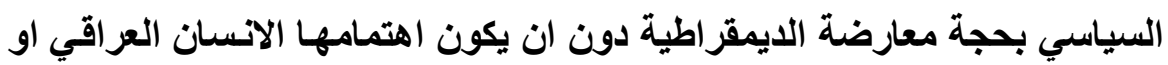

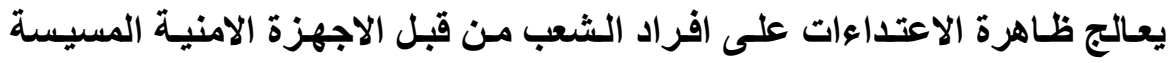

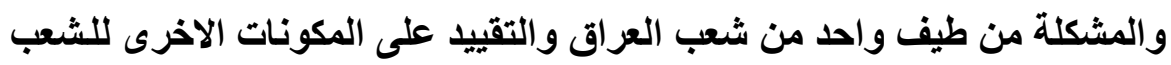
ودون ان يكون له غطاء شرعي قانوني له. r- تبين لنا عقم المؤسسة القضائية العراقية بثقيها القضائي والادعاء العام وعدم قيامهم بدورهم القانوني والاخلاقي المطلوب وصمتهم امسام الانتهاكات المستمرة لحقوق الانسان العراقي دون ان يحركوا ساكنا الا مايطلب من هذا الجهاز تسييره

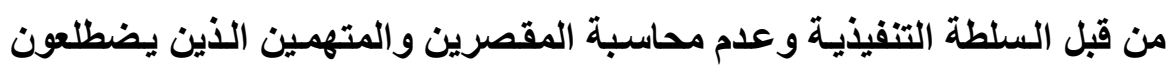

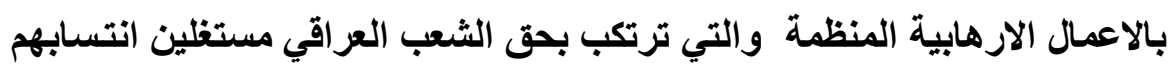

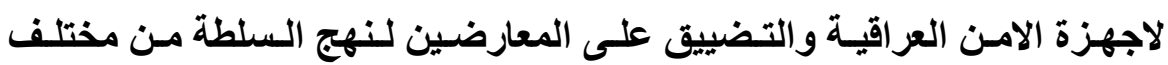
الاشخخاص.

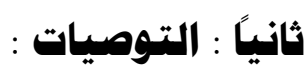
1- ضرورة سن قانون عراقي جليد ينظم حالة الطوارىء بلد القانون الحالي الفاقد

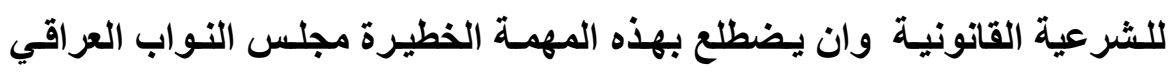

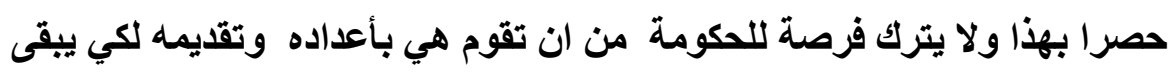

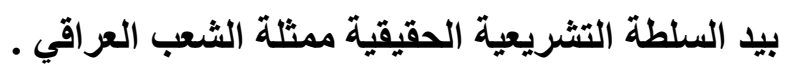
r - تفعيل دور القضاء العراقي وجهاز الادعاء العام بالعراق ليواكب خطورة المرحلة التي يمر بها العراق ومحاسبة المقصرين من الاجهزة الامنية العراقية وتمكين 
المواطنين من اللجوء للقضاء ومقاضات المفسدين وتيسير سبل التقاضي باعتبار ان هذا الحق هو اسـاس كل الحقوق الاخرى بالدولـة والغـاء المحاكم الاستثنائية واصدار قانون يعوض الذين تم ايقافهم ولسنين طوال دون ان توجه لهم تهم دون وجه حق.

r- تفعيل واشر اك مؤسسات المجتمع المدني في رصد حالات انتهاك حقوق الانسان ووسائل الاعلام الحرة غير المسيسة بان تأخذ دورها المنشود في حمايـة حقوق الانسان وتعزيزهـا وضرورة تثقيف القوات الامنية بأهميـة حقوق الاتسان من

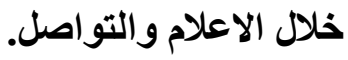

قاعُمة المصادر

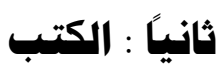

1- ـ د.أبو بكر احمد عثمان ألنعيمي ، حدود سلطات القضاء الإداري في دعوى الإلغاء

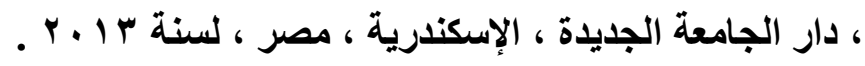

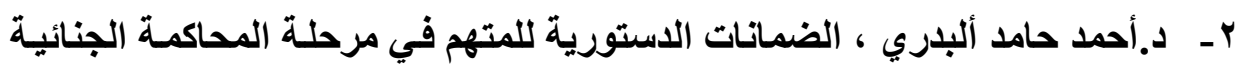
(دراسة مقارنة) ، منشأة المعارف بالإسكندرية .

r- د.أحمد عبد الوهـاب أبو وردة السيد ، حق الإنسان في التقاضسي بين مقتضيات الاحترام ومواطن الأخرى (دراسة مقارنة) ، دار النهضة العربية ، القاهرة .

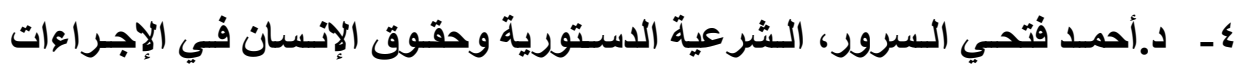

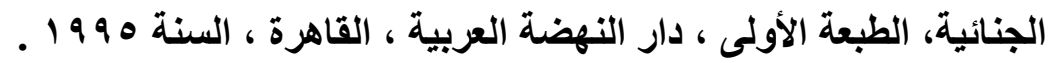
هـ ـ د.أحمــ فتحسي السرور، قـانون أصـول الإجـراءات الجنائيـة ،الجـزء الأول ، دار

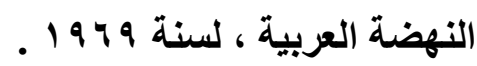


צ- د.أسامة عبد الله قايد، الحماية الجنائية للحياة الخاصة وبنوك المعلومـات (دراسـة

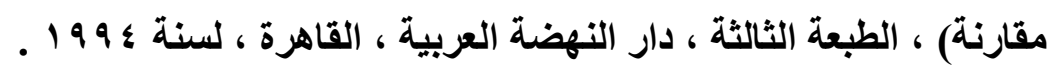
V- ـ د.ثروت بـدوي، الـنظم السياسية، النظرية العامـة للنظم السياسية، دارالنهضة

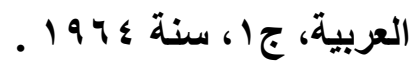

^- ـ ثنـاء فؤاد عبد الله ، خصوصية طرح الايمقراطيـة في الواقع العربـي ، مركز

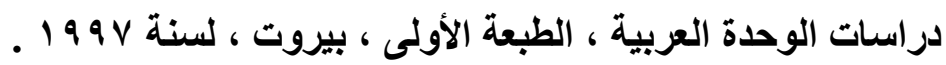
9- ـ د.جعفر عبد السلام علي،القـانون الدولي لدقوق الإنسان ، دراسـة في القـانون والثريعة الإسلامية ، دار الكتاب العربي ، القاهرة ، ودار الكتاب اللبناني ، بيروت . Ib،

ـ 1 ـ جورج فوديل وبيار ولفولفية ، القـانون الإداري ، الجزء الأول ، ترجمة منصور القاضي ، المؤسسة الجامعية للاراسة والنشر والتوزيع ، بيروت ، الطبعة الأولى ،

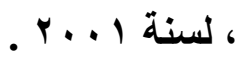

1 ا ـ جون الستر ورون سلاجساد،الاستورية والديمقراطية،ترجمة سميرعزت نصار، مراجعة د. فـاروق منصور ، دار النشر للنشر والتوزيع ، عمـان ، الأردن لسنة

r ا ـ د.حسن شـلبي يوسـف، الـضمانات الاسـتورية للحريـة الثخصية في النظـامين الانكليزية والأمريكي بالمقارنة مع النظام المصري (التفيش والضبط)،دار النهضة

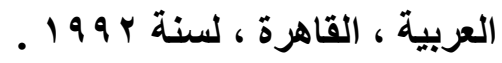

ب ا ـ د.حمدي عطية مصطفى عامر ، حمايـة حقوق الإنسان وحرياته الأساسية ، طا،

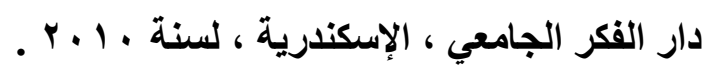


ـ ا ــدخاموش عمر عبد الله ، تأثير قوانين الطوارئ على حريات الأفراد في الاسـاتير

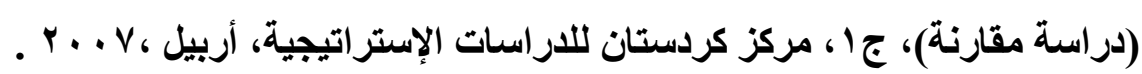

ه 1 ـ د.خضر خضر ، مــخل السى الحريـات العامـة وحقوق الإنسـان، طا ، المؤسسة

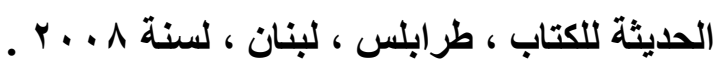

17 ـ ـــرمـزي طـه الـشاعر، النظريـة العامـة للقـانون والدستور، مطـابع دار السياسة

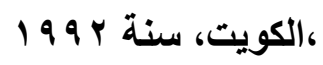

V ا ـ د.زكريا محفوظ ،حالة الطوارئ(دراسة مقارنة)،طا ،منشأة المعارف، الإسكندرية 1979

1 1 ـ د.سامي جمال الدين، لوائح الضرورة وضمانة الوقاية القضائية، منشأة المعارف،

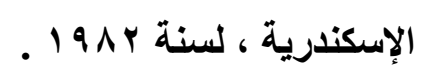

9 ا ـ سـردار علـي عزيز، ضمانات المحاكمـة العادلة للمتهم دراسـة مقارنـة بالشريعة

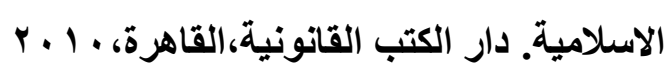

• ـ ـ د.سعدي محمد الخطيب ، حقوق الإنسان وضماناتها الاستورية ، الطبعة الأولى ،

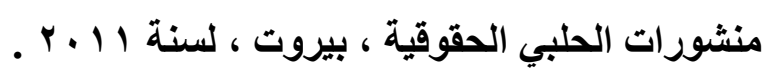

ا Yـ د.الـسيدأحمد المــني،القانون الإداري الليبـي، دار التهـضة العربيـة،القاهرة، $.1970-197 \varepsilon$

Y r ـ د. عبد الحميد الشورابي، البطلان الجنـائي، منشأة المعارف،الإسـندرية، لسنة I $91 \mathrm{r}$

r r ـ د. عصدم الدبس، النظم السياسية الحقوق والحريـات العامـة وضـمانات حمايتها،

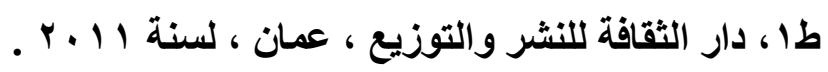


צ Y ـ د. عصام عبد الوهـاب البرزنجي ، السلطة التقديريـة للإدارة والرقابـة القضائية ،

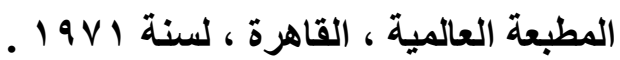

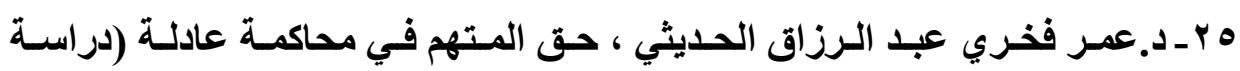

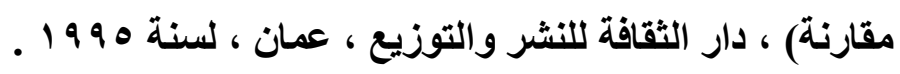

ج بـ د.غازي حسن، الوجيز في حقوق الانسان وحرياته الاساسية، طا ، دار الثقافة

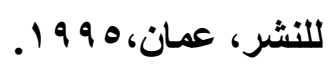

V ـ ـ ـ قدري عبد الفتاح الشهاوي، مناط الحريـات والاستدلالات والاستخبارات،منشأة

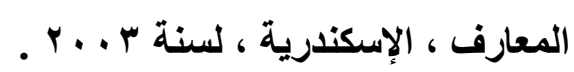

^ץ ـ د.محمـد الوكيـل ، حالــة الطـوارئ وسـلطات الـضبط الإداري (دراسـة مقارنـة) ، الطبعة الثانية ، لسنة ب . . r ـوالطبعة الثانية المنشورة على الانترنيت. q ץ ـ د. محمـد صـلاح عبد البـديع السيد ، الحمايـة الدستورية للحريـات العامـة بـين المشرع والقضاء ، الطبعة الثانية ، دار النهضة العربية ، القاهرة ، لسنة و ، . ب.

• ــــ دممد علي آل ياسين ، القانون الإداري ، المكتبة الحديثة ، بيروت . ا اــ د. مصطفى أبو زيد فهمي، الدستور المصري، بدون طبعة،منشأة دار المعـارف

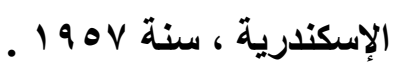

r r ـ د. مصطفى احمد عبد الجواد حجازي ، المسؤولية المدينة للصحفي عند انتهاك

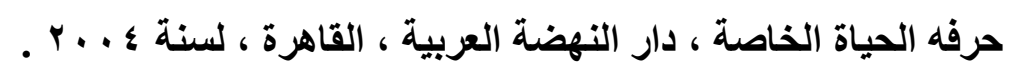

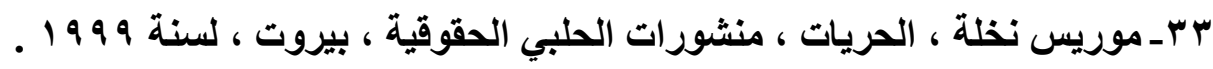

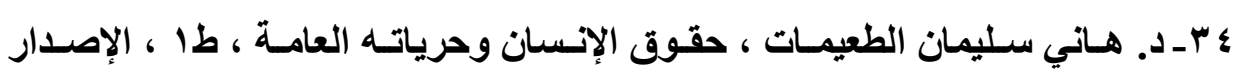
الثاني دار الثروق للنشر والتوزيع ، عمان ، لسنة ب . . ب ـ 


\section{ثالثًا : أطاريح الدكتوراه ورسائل الماجستير}

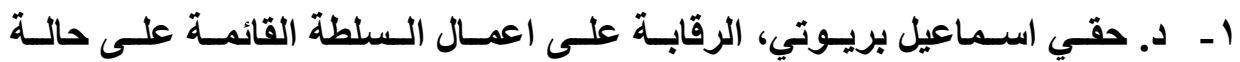

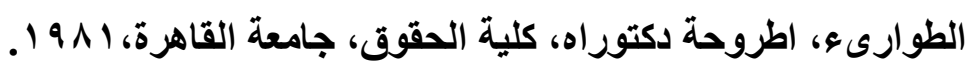

ץ- د. سـحر محمــ نجيب جـرجيس البيـاتي ، التنظيم الاسـتوري للضمانات حقـوق الإنسـان وحرياته (دراسـة مقارنـة) في بعض الاسـاتير ، أطروحة دكتوراه، كلية

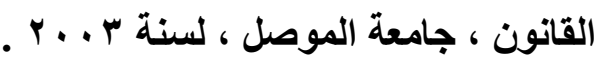

ץ- ـــ مجدي متـولي السيد يوسـف، أثر الظروف ألاستثنائية على مبدأ ألشرعية" دراسة مقارنة"، اطروحة دكتور اه، كلية الحقوق، جامعة عين شمس، ، 99 1 . ع - أفين خالد عبد الرحمن، ضمانات حقوق ألانسان في ظل حالة ألطوارى؛، رسـالة ماجستير، كلية القانون والسياسة، جامعة دهوك. العراق، ه . . . . . هـ سعدون عنتر الجنابي ، أحكام الظروف ألاستثائية في التشريع العراقي ، رسـالة ماجستير ، كلية القانون ، جامعة بغداد ، 1911 ـ צ-عمـاد خليل إبراهيم ، القانون الـولي لحقوق الإنسـان في ظل العولمـة ، رسـالة

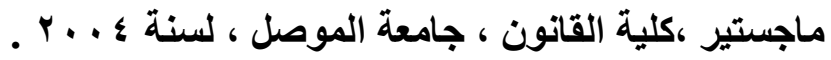
V- كاظم علي الجنابي ، سلطات رئيس الدولة التشريعية في ظل الظروف الاستثنائية

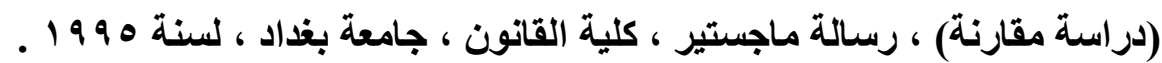

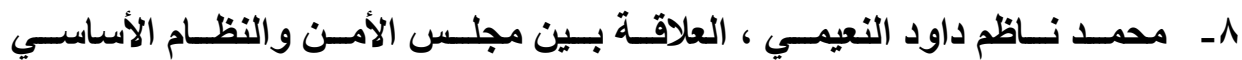

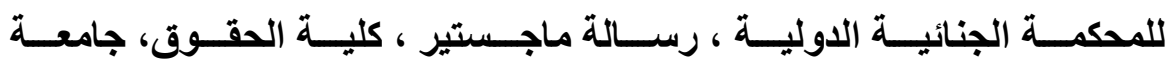

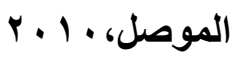


رابعًا : الدوريات :

1 - عامر الجومرد ، المعاهدات في ظل الفصل السابع من ميثاق الأمم المتحدة ، مجلة

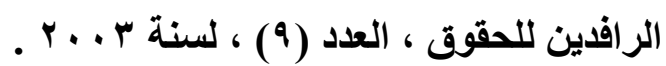

r - د. وليد خالد عطية،الانفتاح الالكتروني وأثره على الحق في الحياة الخاصة،ببحث

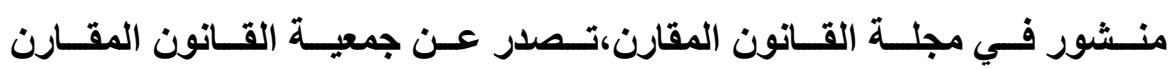

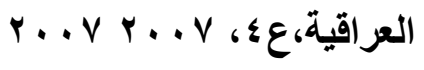

خاهساً : الدساتير والمواثيق الدولية والقوانين والمراسيم:1- دستور جمهورية العراق لسنة ه ... ب.

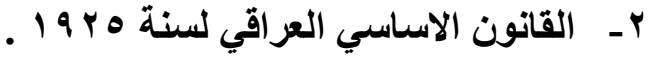
r- دستور جمهورية مصر العربية لسنة ع ا ب r.

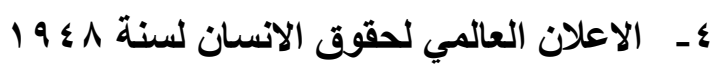
0ـ العهد الدولي الخاص بالحقوق المدنية والسياسية لعام 79 ال 19 צ- أمر الدفاع والسلامة الوطنية العراقي لعام ؛ . . . . . V- قانون الطوارىء العراقي رقم • 1 لسنة . ـ 19 .

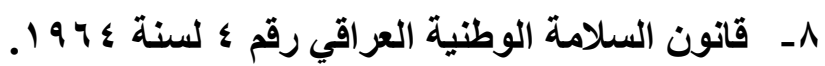

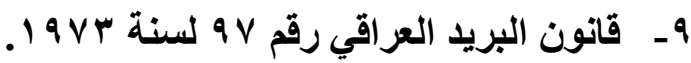

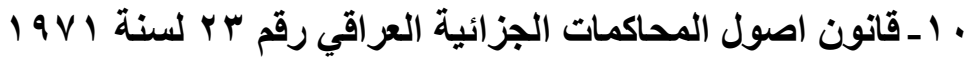
1 ـ ـ مرسوم صيانة الامن العراقي رقم 7 ه لسنة ، ـ 19 
1 - د. عامر الجومرد ، مجموعة محاضرات القيت على طلبة الدراسـات العليا (غير

منشورة) ، ماجستير ، كلية القانون والسياسة ، جامعة دهوك ، للسنة الدراسـة

$$
\text { . r... } \theta_{-} r \ldots \varepsilon
$$

r - عبد الآلـه الخـاني ، نظـام الطوارئ والأحكام العرفيـة ، محاضرة القيت بمناسبة

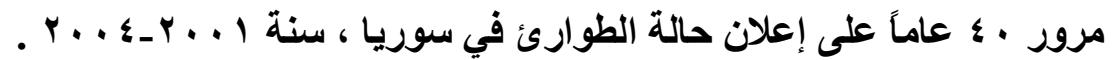

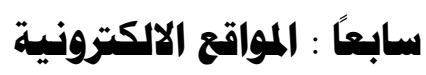

1 - الحق في محاكمة عادلة : www.hrcap.org/areports/reprt25/ch3.htm

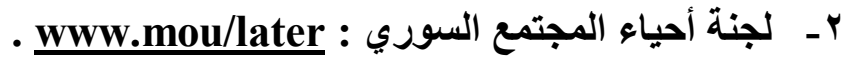

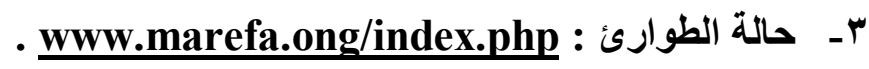
ع - رديف مصطفى - حالة الطوارئ ومبرراتها ، مشروعيتها القانونية والدستورية ، آثار ها وضوابط أعمالها : Www.efrin.net.21-02.2004

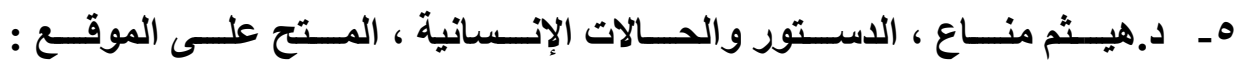
www.hrinfo.ong ثاهنًاً : الاصسادر الأجنبية :

1- John Mcdowney Gunter weich ceds - human rightin . toransition printed inepter lang am bh - fran furt .2003 .

2- Mark VT tush net - Making civil rights law thurgood Marshall, naacp legal defense fund oxford .1993 . 